\title{
Corte Interamericana de Derechos Humanos
}

\section{Caso Almonacid Arellano y otros Vs. Chile}

\section{Sentencia de 26 de septiembre de 2006 (Excepciones Preliminares, Fondo, Reparaciones y Costas)}

En el caso Almonacid Arellano y otros,

la Corte Interamericana de Derechos Humanos (en adelante "la Corte Interamericana", "la Corte" o "el Tribunal"), integrada por los siguientes jueces*:

Sergio García Ramírez, Presidente;

Alirio Abreu Burelli, Vicepresidente;

Antônio A. Cançado Trindade, Juez;

Manuel E. Ventura Robles, Juez; y

Diego García-Sayán, Juez.

presentes, además,

Pablo Saavedra Alessandri, Secretario, y

Emilia Segares Rodríguez, Secretaria Adjunta,

de conformidad con los artículos 62.3 y 63.1 de la Convención Americana sobre Derechos Humanos (en adelante "la Convención" o "la Convención Americana") y con los artículos 29, 31, 53.2, 55, 56 y 58 del Reglamento de la Corte (en adelante "el Reglamento"), dicta la presente Sentencia.

\section{NTRODUCCI ÓN DE LA CAUSA}

1. El 11 de julio de 2005, de conformidad con lo dispuesto en los artículos 50 y 61 de la Convención Americana, la Comisión Interamericana de Derechos Humanos (en adelante "la Comisión" o "la Comisión Interamericana") sometió ante la Corte una demanda contra el Estado de Chile (en adelante "el Estado" o "Chile"), la cual se

\footnotetext{
El Juez Oliver Jackman informó al Tribunal que, por motivos de fuerza mayor, no podía estar presente en la deliberación y adopción de la presente Sentencia. La Jueza Cecilia Medina Quiroga, de nacionalidad chilena, se excusó de participar en la deliberación y firma de la presente sentencia.
} 
originó en la denuncia número 12.057, recibida en la Secretaría de la Comisión el 15 de septiembre de 1998.

2. La Comisión presentó la demanda en este caso con el objeto de que la Corte decidiera si el Estado violó los derechos consagrados en los artículos 8 (Garantías Judiciales) y 25 (Protección Judicial) de la Convención Americana, en relación con la obligación establecida en el artículo 1.1 (Obligación de Respetar los Derechos) de la misma, en perjuicio de los familiares del señor Luis Alfredo Almonacid Arellano. Asimismo, la Comisión solicitó a la Corte que declare que el Estado incumplió con la obligación emanada del artículo 2 (Deber de adoptar disposiciones de derecho interno) de la Convención.

3. Los hechos expuestos por la Comisión en la demanda se refieren a la presunta falta de investigación y sanción de los responsables de la ejecución extrajudicial del señor Almonacid Arellano, a partir de la aplicación del Decreto Ley No. 2.191, ley de amnistía, adoptada en 1978 en Chile, así como a la supuesta falta de reparación adecuada a favor de sus familiares.

4. Además, la Comisión solicitó a la Corte Interamericana que, de conformidad con el artículo 63.1 de la Convención, ordene al Estado que adopte determinadas medidas de reparación indicadas en la demanda (infra párr. 139). Por último, solicitó a la Corte que ordene al Estado el pago de las costas y gastos generados en la tramitación del caso en la jurisdicción interna y ante los órganos del Sistema Interamericano de Protección de los Derechos Humanos.

I I

\section{COMPetencia}

5. Chile es Estado Parte en la Convención Americana desde el 21 de agosto de 1990 y reconoció la competencia contenciosa de la Corte en esa misma fecha. En ese momento declaró que reconocía la competencia de la Corte, conforme a lo dispuesto por el artículo 62 de la Convención, solamente respecto a los "hechos posteriores a la fecha del depósito de este Instrumento de Ratificación o, en todo caso, a hechos cuyo principio de ejecución sea posterior al 11 de marzo de 1990". El Estado ha alegado en sus excepciones preliminares que el Tribunal no tiene competencia para conocer del presente caso (infra párrs. 38). Por lo tanto, la Corte decidirá primero sobre las excepciones preliminares interpuestas por Chile; posteriormente, si fuera jurídicamente procedente, el Tribunal pasará a decidir sobre el fondo y las reparaciones solicitadas en el presente caso.

\section{III}

\section{Procedi mi ento ante la Comisión}

6. El 15 de septiembre de 1998 Mario Márquez Maldonado y Elvira del Rosario Gómez Olivares presentaron una petición ante la Comisión Interamericana, a la cual se dio trámite bajo el número 12.057.

7. El 9 de octubre de 2002 la Comisión Interamericana, durante su 116o período ordinario de sesiones, adoptó el Informe No. 44/02, mediante el cual declaró admisible la petición, en relación con los artículos 1.1, 8 y 25 de la Convención Americana. Dicho informe fue transmitido el 29 de octubre de 2002 al Estado y a los peticionarios. 
8. En el marco de su $122^{\circ}$ Período Ordinario de Sesiones, el 7 de marzo de 2005, la Comisión aprobó el Informe de Fondo No. 30/05, en observancia del artículo 50 de la Convención. En éste, concluyó que el Estado violó los derechos consagrados en los artículos 8 y 25 de la Convención Americana, en conexión con los artículos 1.1 y 2 de la misma, en perjuicio de los familiares del señor Almonacid Arellano, y efectuó una serie de recomendaciones a efectos de subsanar tales violaciones.

9. El Informe de Fondo fue notificado al Estado el 11 de abril de 2005 y se le concedió el plazo de dos meses para que se pronunciara sobre la implementación de las recomendaciones. El 24 de junio de 2005 el Estado solicitó a la Comisión que prorrogara el plazo otorgado hasta el 8 de julio de 2005. La Comisión otorgó una prórroga al Estado, pero hasta el 1 de julio de 2005.

10. El 20 de junio de 2005, de conformidad con lo dispuesto por el artículo 43.3 de su Reglamento, la Comisión notificó a los peticionarios la adopción del Informe de Fondo y la transmisión de éste al Estado, y les solicitó que expresaran su posición respecto del sometimiento del caso a la Corte Interamericana. Mediante comunicación de 27 de junio de 2005, los peticionarios solicitaron que la Comisión enviara el caso a la Corte.

11. El 11 de julio de 2005, ante la falta de información del Estado sobre la implementación de las recomendaciones del informe aprobado de acuerdo al artículo 50 de la Convención Americana (supra párr. 8), y de conformidad con lo dispuesto en los artículos $51(1)$ de la Convención y 44 de su Reglamento, la Comisión Interamericana decidió someter el presente caso a la Corte. Ese mismo día, el Estado remitió a la Comisión, fuera del plazo establecido (supra párr. 9), su informe sobre el cumplimiento de las recomendaciones contenidas en Informe de Fondo No. 30/05.

\section{IV \\ Procedi mi ento ante la Corte}

12. El 11 de julio de 2005 la Comisión presentó una demanda ante la Corte en relación con el presente caso. Los anexos a la demanda fueron presentados el 18 de julio de 2005. La Comisión designó como Delegados ante la Corte al Comisionado Evelio Fernández Arévalos y al Secretario Ejecutivo Santiago A. Canton, y como asesores legales a los señores Ariel E. Dulitzky, Víctor H. Madrigal Borloz, Juan Pablo Albán y Christina M. Cerna.

13. El 27 de julio de 2005 la Secretaría de la Corte (en adelante "la Secretaría"), previo examen preliminar de la demanda realizado por el Presidente de la Corte (en adelante "el Presidente"), la notificó, junto con sus anexos, al Estado y le informó sobre los plazos para contestarla y designar representación en el proceso. El mismo día, de conformidad con lo dispuesto en el artículo 35.1.d y e del Reglamento, la Secretaría notificó la demanda al señor Mario Márquez Maldonado, designado en la demanda como representante de la presunta víctima y sus familiares (en adelante "el representante"), y le informó que contaba con un plazo de dos meses para presentar su escrito de solicitudes, argumentos y pruebas (en adelante "escrito de solicitudes y argumentos").

14. El 22 de agosto de 2005 el Estado designó como Agente a la señora Amira Esquivel Utreras y como Agente Alterno al señor Miguel González Morales. 
15. El 26 de septiembre de 2005 el representante presentó su escrito de solicitudes y argumentos, y el 29 de septiembre de 2005 los anexos al mismo.

16. Los días 18 y 25 de noviembre de 2005 el Estado informó a la Corte que el 17 de octubre del mismo año la Comisión Interamericana consultó al Estado si "tendría interés en iniciar el proceso de solución amistosa".

17. El 26 de noviembre de 2005 el Estado presentó un escrito mediante el cual interpuso excepciones preliminares, contestó la demanda y remitió sus observaciones al escrito de solicitudes y argumentos (en adelante "contestación de la demanda"). Las excepciones preliminares interpuestas se refieren a la supuesta incompetencia ratione temporis de la Corte para conocer del presente caso y a una supuesta violación procesal durante la tramitación del caso ante la Comisión que habría violado el derecho del Estado a ser oído. El 23 de diciembre de 2005 el Estado presentó los anexos a su contestación de la demanda.

18. El 8 de diciembre de 2005 la Secretaría, de conformidad con el artículo 37.4 del Reglamento, otorgó a la Comisión y a los representantes un plazo de treinta días, para que presentaran sus alegatos escritos sobre las excepciones preliminares interpuestas (supra párr. 17). El representante no presentó observaciones.

19. El 6 de enero de 2006 la Comisión remitió sus observaciones escritas a las excepciones preliminares interpuestas por el Estado, a las cuales adjuntó prueba documental.

20. El 7 de febrero de 2006 la Corte dictó una Resolución mediante la cual estimó conveniente recibir, a través de declaración rendida ante fedatario público (affidávit) la declaración del señor Cristián Correa Montt, propuesto como testigo por el Estado. Asimismo, el Presidente convocó a la Comisión, al representante y al Estado a una audiencia pública que se celebraría en la sede del Superior Tribunal de Justicia del Brasil, en la ciudad de Brasilia, a partir del 29 de marzo de 2006, para escuchar sus alegatos finales orales sobre las excepciones preliminares y eventuales fondo, reparaciones y costas en el presente caso, así como las declaraciones de los señores Elvira Gómez Olivares, propuesta como testigo por el representante, Jorge Correa Sutil, propuesto como testigo por el Estado, Humberto Raúl I gnacio Nogueira Alcala, propuesto como perito por la Comisión, y Cristián Maturana Miquel, propuesto como perito por el Estado. Además, en la referida Resolución el Presidente informó a las partes que contaban con plazo hasta el 12 de mayo de 2006 para presentar sus alegatos finales escritos en relación con las excepciones preliminares y eventuales fondo, reparaciones y costas.

21. El día 10 de marzo de 2006 el Estado remitió la declaración rendida por el señor Cristián Correa Montt solicitada por la Corte (supra párr. 20). Los anexos a dicha declaración fueron recibidos el 21 de marzo de 2006.

22. El 16 de marzo de 2006 el Estado informó que por motivos de fuerza mayor, el testigo Cristián Maturana Miquel, convocado a comparecer ante la Corte Interamericana en audiencia pública (supra párr. 20), estaba imposibilitado de trasladarse a la ciudad de Brasilia, por lo que no podría rendir su declaración. Por esta razón, el Estado solicitó a la Corte que se le permita sustituir dicho peritaje por el del señor Alejandro Salinas Rivera y que se autorice que el señor Maturana Miquel rinda su declaración a través de fedatario público (affidávit). Ese mismo día, la Secretaría, 
siguiendo instrucciones del Presidente, requirió a la Comisión y al representante que presentaran las observaciones que creyesen convenientes a la solicitud del Estado.

23. El 17 de marzo de 2006 la Comisión presentó sus observaciones, en las que señaló que no tenía objeciones a la solicitud para que se reciba la declaración del señor Maturana Miguel por medio de affidávit. Por otro lado, la Comisión señaló que la solicitud del Estado de proponer como nuevo perito al señor Salinas Rivera "resulta improcedente", en "aplicación del principio de preclusión y dado que el Estado no utilizó la oportunidad procesal pertinente", y estimó que el ofrecimiento del señor Salinas Rivera como perito "no constituye una sustitución, sino una adición". Asimismo, la Comisión indicó que "se verifica impedimento" del señor Salinas Rivera para prestar su declaración, puesto que "el presente asunto fue sometido a consideración del Sistema Interamericano [...] cuando el señor Salinas Rivera ya prestaba sus servicios en el área de derechos humanos del Ministerio de Relaciones Exteriores de Chile".

24. El 17 de marzo de 2006 el representante de las presuntas víctimas presentó observaciones a la declaración del señor Cristián Correa Montt (supra párr. 21).

25. El 21 de marzo de 2006 el Estado informó que retiraba "como perito propuesto, al [señor] Alejandro Salinas Rivera, estimando atendible la razón expuesta por la Comisión Interamericana" (supra párr. 23), y que en su reemplazo designaba al señor Jean Pierre Matus Acuña. Asimismo, el Estado insistió "en su petición de que se autorice al [señor] Cristián Maturana Miquel, a presentar su informe ante fedatario público".

26. El 22 de marzo de 2006 la Comisión presentó sus observaciones en relación con la declaración del testigo Cristián Correa Montt. El mismo día presentó sus observaciones sobre el ofrecimiento del Estado de la declaración del señor Jean Pierre Matus Acuña (supra párr. 25), en las que manifestó su oposición a tal ofrecimiento, en vista de que "no constituye una sustitución, sino una adición".

27. El 24 de marzo de 2006 el Presidente de la Corte Interamericana emitió una Resolución, mediante la cual decidió aceptar que el señor Cristián Maturana Miquel presente su peritaje a través de declaración rendida ante fedatario público (affidávit), así como convocar al señor Jean Pierre Matus Acuña para que rinda su experticia ante el Tribunal en la audiencia pública convocada por el mismo (supra párr. 20).

28. El 29 de marzo de 2006 se celebró la audiencia pública en la ciudad de Brasilia, Brasil, a la cual comparecieron: a) por la Comisión Interamericana: Evelio Fernández Arévalos y Santiago Canton, Delegados; Víctor H. Madrigal Borloz y Juan Pablo Albán, Asesores; b) por los representantes: Mario Eugenio Márquez Maldonado y Ricardo Zúñiga Lizama, y c) por el Estado: Amira Esquivel Utreras, Agente; René Ruidíaz Pérez, Primer Secretario de la Embajada de Chile en Brasil; Patricio Aguirre Vacchieri, Segundo Secretario de la Dirección de Derechos Humanos del Ministerio de Relaciones Exteriores de Chile; y Virginia Barahona, abogada de la Dirección de Derechos Humanos del Ministerio de Relaciones Exteriores de Chile. Asimismo, comparecieron la señora Elvira Gómez Olivares, testigo ofrecida por el representante, y Jorge Correa Sutil, testigo ofrecido por el Estado, y los señores Humberto Raúl Ignacio Nogueira Alcala y Jean Pierre Matus Acuña, peritos ofrecidos por la Comisión y el Estado, respectivamente. Los peritos Humberto Raúl Ignacio Nogueira Alcala y Jean Pierre Matus Acuña presentaron documentación en la audiencia pública. Asimismo, durante la audiencia la Corte solicitó al Estado la remisión de prueba documental. 
29. El 19 de abril de 2006 el Estado remitió la declaración jurada del señor Cristián Maturana Miquel.

30. El 19 de abril de 2006 la Asociación Americana de Juristas de Valparaíso/Aconcagua presentó un escrito en calidad de amicus curiae, al cual adjuntó documentación.

31. El 28 de abril de 2006 el representante de las presuntas víctimas presentó sus alegatos finales escritos. Adjuntó a los mismos prueba documental.

32. El 2 de mayo de 2006 la Comisión presentó sus observaciones a la declaración jurada rendida por el señor Cristián Maturana Miquel. La Comisión solicitó a la Corte que "no tome en cuenta la declaración jurada del señor Maturana Miquel, por encontrarse fuera del objeto para el que fue solicitada".

33. El 22 de mayo de 2006 la Comisión y el Estado presentaron sus alegatos finales escritos. El Estado adjuntó prueba documental, así como los documentos solicitados por la Corte en la audiencia pública (supra párr. 28).

34. El 14 de junio de 2006 la Comisión objetó los anexos al escrito de alegatos finales presentados por el Estado. La Comisión señaló que "en virtud del principio de preclusión" y dado que el Estado no presentó esos documentos en la etapa procesal oportuna, "dichos documentos deben ser objeto de rechazo de plano". Asimismo, la Comisión solicitó que "en el supuesto de que la [...] Corte decidiera admitir la documentación cuestionada [...], se garantice el equilibrio procesal, concediendo a las partes una oportunidad para formular observaciones al contenido de los documentos presentados".

35. El 14 de junio de 2006 la Secretaría, siguiendo instrucciones del Presidente, informó a la Comisión que el Tribunal, en seguimiento del equilibrio procesal y del principio del contradictorio, transmite a las partes toda la documentación que una de ellas le presenta, a efectos de que puedan pronunciarse sobre la misma. A tal efecto, el Tribunal no concede plazos, en el entendido de que es una facultad, mas no una obligación, que la parte interesada presente observaciones. En el presente caso, la Secretaría transmitió a la Comisión Interamericana y al representante los documentos remitidos por el Ilustrado Estado junto con sus alegatos finales escritos. La Comisión tenía la potestad de presentar observaciones a tal documentación, como en efecto lo hizo mediante el escrito de 14 de junio de 2006 (supra párr. 34). Asimismo, la Secretaría informó a la Comisión que si deseaba ampliar sus observaciones, podía remitirlas al Tribunal a la mayor brevedad. La Comisión no presentó observaciones adicionales.

36. El 6 de julio de 2006 el representante de las presuntas víctimas remitió copias legibles de parte de la documentación presentada junto con sus alegatos finales escritos (supra párr. 31), así como documentación adicional.

37. El 27 de julio de 2006 el Estado presentó sus observaciones en relación con las observaciones efectuadas con fecha de 2 de mayo de 2006 por la Comisión respecto de la declaración jurada rendida por el señor Cristián Maturana Miquel (supra párr. 32). A este escrito el Estado adjuntó prueba documental. 


\section{Excepci ones Preli mi nares}

38. El Estado, en su contestación a la demanda (supra párr. 17), formuló de manera nominada dos excepciones preliminares, a saber: i) incompetencia ratione temporis de la Corte para conocer del presente caso, y ii) violaciones al procedimiento ante la Comisión Interamericana. Sin embargo, en la inteligencia de este Tribunal, de los diversos alegatos presentados por Chile se infiere la existencia de otra objeción a la competencia de la Corte: falta de agotamiento de los recursos internos. Si bien el Estado no calificó este argumento como una excepción preliminar, la Corte considera oportuno pronunciarse al respecto en este capítulo.

\section{Pri mera Excepci ón Preli mi nar Competencia de la Corte Ratione Temporis}

39. Alegatos del Estado

a) el Estado, al momento del depósito del Instrumento de Ratificación de la Convención y reconocimiento de la competencia de la Corte Interamericana, con fecha 21 de agosto de 1990, manifestó que tal reconocimiento de competencia se refiere a "hechos posteriores a la fecha del depósito del Instrumento de Ratificación o, en todo caso, a hechos cuyo principio de ejecución sea posterior al 11 de marzo de 1990";

b) el hecho que sustenta la acción penal es el delito de homicidio cometido en contra del señor Almonacid, hecho acaecido el 17 de septiembre del año 1973 y que se encuentra cubierto por la Declaración de incompetencia ratione temporis formulada por el Estado, por haber acontecido con anterioridad al 11 de marzo de 1990;

c) la investigación criminal constituye un todo único y continuo, permanente en el tiempo. Se trata de un proceso judicial, que tiene su inicio en el mes de septiembre del año 1973, en el cual se dictan sucesivos sobreseimientos. El proceso no es susceptible de ser parcializado, dividido, separado o escindido, ni siquiera material o formalmente, es y ha seguido siendo siempre, en forma invariable y permanente en el tiempo, uno solo, con una foliación continua, al igual que su tramitación, y

d) las acciones judiciales intentadas por los familiares de la víctima, con posterioridad al año 1990, no tienen un carácter de "hechos independientes", carácter que, además, es ajeno a la realidad material, formal y jurídica.

40. Alegatos de la Comisión

a) hay hechos y efectos que se han producido con posterioridad al reconocimiento de la competencia de la Corte, que permanecen y se repiten, y tienen comienzo y ejecución con posterioridad a la aceptación de competencia contenciosa del Tribunal por parte del Estado. Entre estos hechos autónomos, que tienen relación con la violación a los artículos 8 y 25 de la Convención, están los siguientes:

i) la remisión del caso, el 5 de diciembre de 1996, a la jurisdicción militar, pese a tratarse de delitos comunes, que no corresponden a actos de servicio del personal involucrado; 
ii) las omisiones de investigación, procesamiento y sanción de los responsables del homicidio del señor Almonacid Arellano, a partir del 11 de marzo de 1990;

iii) la sentencia de 28 de enero de 1997 del tribunal militar inferior que sobreseyó al supuesto responsable de la muerte del señor Almonacid Arellano;

iv) la confirmación de esa sentencia por parte de la Corte Marcial el 25 de marzo de 1998, la que además estableció que resultaba aplicable la ley de auto amnistía de 1978;

v) la omisión del Ministerio Público Militar de impugnar la decisión de la Corte Marcial de 25 de marzo de 1998; y

vi) la omisión de la Corte Suprema de Justicia de Chile de ejercer de oficio el control de constitucionalidad del Derecho Ley de auto amnistía No. 2.191, según lo previsto por el artículo 80 de la Constitución;

b) estas actuaciones $u$ omisiones judiciales constituyen actos de incumplimiento del Estado con sus obligaciones de investigar efectiva y adecuadamente; y omisiones en proporcionar un recurso efectivo que sancione a los inculpados por la comisión del delito. En todos los casos, se configuran violaciones convencionales específicas y autónomas, ocurridas después del reconocimiento de la competencia de la Corte Interamericana, y

c) los hechos violatorios de la obligación estatal de legislar de conformidad con la Convención constituyen también materia sobre la cual el Tribunal es competente. En el caso particular de legislación contraria a la Convención Americana, su continuada vigencia, con independencia de su fecha de promulgación, es de hecho una violación repetitiva de las obligaciones contenidas en el artículo 2 convencional. Adicionalmente, todo acto de aplicación de dicha ley en afectación del los derechos y libertades protegidos en la Convención debe ser considerado como un acto violatorio autónomo.

\section{Alegatos del Representante}

a) el presente juicio internacional no es sobre el homicidio del señor Almonacid Arellano, acaecido en septiembre 1973, sino sobre la denegación de justicia recaída en la investigación de dicho delito, lo que es una infracción distinta aunque relacionada con el homicidio indicado;

b) el principio de ejecución de la denegación de justicia empieza el 25 de septiembre de 1996, cuando la justicia militar reclamó para sí la competencia para conocer del delito de homicidio; continuó con la resolución de fecha 5 de diciembre de 1996 de la Corte Suprema que, dirimiendo la competencia entre la justicia militar y la justicia civil, lo hizo a favor de la primera; luego siguió con la resolución de fecha 28 de enero de 1997 del Juez del Segundo Juzgado Militar de Santiago que sobreseyó definitivamente la causa y se consumó finalmente con la resolución de 25 de marzo de 1998 de la Corte Marcial, que confirmó el antes dicho sobreseimiento definitivo. Por lo tanto, todos los hechos constitutivos de la denegación de justicia acaecieron con posterioridad al 12 de marzo de 1990, y

c) el bien jurídico protegido por el delito de homicidio es el derecho a la vida y en el caso de la denegación lo es la probidad de la justicia. Por lo tanto, el 
homicidio y la denegación de justicia son conductas relacionadas, pero independientes y jurídicamente autónomas.

\section{Consideraciones de la Corte}

42. El fundamento de la primera excepción preliminar interpuesta por el Estado radica en su "declaración" realizada al reconocer la competencia de la Corte el 21 de agosto de 1990, la cual establece que:

\section{$[\ldots]$}

b) El Gobierno de Chile declara que reconoce como obligatoria de pleno derecho la competencia de la Corte Interamericana de Derechos Humanos respecto de los casos relativos a la interpretación y aplicación de esta Convención de conformidad con lo que dispone su artículo 62.

[...] el Gobierno de Chile deja constancia que los reconocimientos de competencia que ha conferido se refieren a hechos posteriores a la fecha del depósito de este instrumento de ratificación o, en todo caso, a hechos cuyo principio de ejecución sea posterior al 11 de marzo de 1990. Igualmente el Gobierno de Chile, al conferir la competencia a la Comisión y a la Corte Interamericana de Derechos Humanos, declara que estos órganos, al aplicar lo preceptuado en el párrafo segundo del artículo 21 de la Convención no podrán pronunciarse acerca de las razones de utilidad pública o de interés social que se hayan tenido en consideración al privar de sus bienes a una persona.

43. De acuerdo a la jurisprudencia desarrollada por esta Corte, debe entenderse que la "declaración" realizada por Chile constituye una limitación temporal al reconocimiento de la competencia de este Tribunal, y no una "reserva". En efecto, el Tribunal ha sostenido que

[el] "reconocimiento de la competencia" de la Corte [...] es un acto unilateral de cada Estado[,] condicionado por los términos de la propia Convención Americana como un todo $y$, por lo tanto, no está sujeta a reservas. Si bien alguna doctrina habla de "reservas" al reconocimiento de la competencia de un tribunal internacional, se trata, en realidad, de limitaciones al reconocimiento de esa competencia y no técnicamente de reservas a un tratado multilateral ${ }^{1}$.

44. Asimismo, conforme a la jurisprudencia de este Tribunal, este tipo de limitaciones temporales al reconocimiento de la competencia de la Corte tienen su fundamento en la facultad, que otorga el artículo 62 de la Convención a los Estados Partes que decidan reconocer la competencia contenciosa del Tribunal, de limitar temporalmente dicha competencia ${ }^{2}$. Por lo tanto, esta limitación se encuentra prevista en la propia Convención.

45. Corresponde ahora al Tribunal, teniendo en cuenta los principios y parámetros anteriormente expuestos, determinar si puede conocer de los hechos que fundamentan las alegadas violaciones a la Convención en el presente caso. Además, la Corte resalta que, de acuerdo al principio de compétence de la compétence, no puede dejar a la voluntad de los Estados que éstos determinen cuáles hechos se encuentran excluidos

1 Cfr. Caso Hermanas Serrano Cruz. Excepciones Preliminares. Sentencia de 23 de noviembre de 2004. Serie C No. 118, párr. 61; Caso Alfonso Martín del Campo Dodd. Excepciones Preliminares. Sentencia de 3 de septiembre de 2004. Serie C No. 113, párr. 68; y Caso Cantos. Excepciones Preliminares. Sentencia de 7 de septiembre de 2001. Serie C No. 85, párr. 34. 
de su competencia. Esta determinación es un deber que corresponde al Tribunal en el ejercicio de sus funciones jurisdiccionales ${ }^{3}$.

46. La Comisión y el representante han señalado que la Corte es competente para pronunciarse sobre una serie de hechos que, según su criterio, tuvieron principio de ejecución con posterioridad al reconocimiento de la competencia de la Corte (supra párr. 40.a y 41.b). Esos hechos básicamente se refieren a tres aspectos: i) el otorgamiento de competencia a la jurisdicción militar en perjuicio de la jurisdicción civil, ii) la vigencia del Decreto Ley No. 2.191 con posterioridad a la entrada en vigor de la Convención Americana para Chile, y iii) la aplicación de ese Decreto Ley en el presente caso por parte de las autoridades judiciales militares. Todas estas, supuestas violaciones cometidas en perjuicio de los familiares del señor Almonacid Arellano. Ni la Comisión ni el representante solicitan que la Corte se pronuncie sobre la detención y muerte del señor Almonacid Arellano, ni señalan ninguna falencia o violación procesal, o cualquier otro hecho ocurrido antes de la ratificación de la Convención.

47. De otra parte, el Estado alegó que "la investigación criminal [...] constituye un todo único y continuo, permanente en el tiempo", que no "es susceptible de ser parcializado, dividido o escindido, ni siquiera material o formalmente". Por tanto, concluye el Estado, el principio de ejecución de la supuesta violación es anterior al reconocimiento de competencia de la Corte, dado que el proceso de investigación por la muerte del señor Almonacid Arellano se inició en el mes de septiembre de 1973.

48. Esta Corte ha considerado que en el transcurso de un proceso se pueden producir hechos independientes que podrían configurar violaciones específicas y autónomas de denegación de justicia ${ }^{4}$. Por ejemplo, la decisión de un juez de no permitir la participación del defensor del acusado en el proceso ; la prohibición a los defensores de entrevistarse a solas con sus clientes, conocer oportunamente el expediente, aportar pruebas de descargo, contradecir las de cargo y preparar adecuadamente los alegatos ${ }^{6}$; la actuación de jueces y fiscales 'sin rostro'7, el sometimiento al acusado a torturas o maltratos para forzar una confesión ${ }^{8}$; la falta de comunicación al detenido extranjero de su derecho de asistencia consular ${ }^{9}$, y la violación del principio de coherencia o de correlación entre acusación y sentencia ${ }^{10}$, entre otros.

49. En vista de ello, la Corte considera que es competente para pronunciarse sobre los hechos señalados por la Comisión y los representantes referentes al otorgamiento

3 Cfr. Caso Hermanas Serrano Cruz. Excepciones Preliminares, supra nota 1, párr. 74.

$4 \quad$ Cfr. Caso Hermanas Serrano Cruz. Excepciones Preliminares, supra nota 1, párr. 84.

5 Cfr. Caso Comunidad indígena Yakye Axa. Sentencia 17 de junio de 2005. Serie C No. 125, párr.

117.

6 Cfr. Caso Castillo Petruzzi y otros. Sentencia de 30 de mayo de 1999. Serie C No. 52, párrs. 135 a

156.

$7 \quad$ Cfr. Caso Lori Berenson Mejía. Sentencia de 25 de noviembre de 2004. Serie C No. 119, párr. 147.

$8 \quad$ Cfr. Caso Tibi. Sentencia de 7 de septiembre de 2004. Serie C No. 114, párr. 146.

$9 \quad$ Cfr. Caso Acosta Calderón. Sentencia de 24 de junio de 2005. Serie C No. 129, párr. 125.

10 Cfr. Caso Fermín Ramírez. Sentencia de 20 de junio de 2005. Serie C No. 126, párrs. 65 a 69. 
de competencia a la jurisdicción militar en perjuicio de la jurisdicción civil, y a la aplicación de la Ley de Amnistía en el presente caso por parte de las autoridades judiciales militares, puesto que ocurrieron con posterioridad al 21 de agosto de 1990 . Dichos hechos se encuentran detallados en el párrafo 82.11 a 82.23 de la presente Sentencia y podrían constituir violaciones autónomas de los artículos 8.1 y 25 de la Convención, en relación con el artículo 1.1 de la misma. En consecuencia, el Tribunal estima que no están excluidos por la limitación realizada por el Estado. De otra parte, acerca de las supuestas "omisiones de investigación, procesamiento y sanción de los responsables del homicidio del señor Luis Almonacid" alegadas por la Comisión (supra párr. 40.a.ii), la Corte advierte que ni ésta ni el representante precisaron cuáles son esas omisiones, por lo que la Corte no puede determinar a cuáles hecho se refieren y, por ende, la fecha en que ocurrieron, por lo que desestima tal argumento.

50. En lo que se refiere a la vigencia del Decreto Ley No. 2.191, no puede alegarse que el principio de ejecución del supuesto incumplimiento del artículo 2 de la Convención Americana se haya dado con la promulgación de éste en 1978, y que por ende la Corte no tiene competencia para conocer ese hecho. El principio de ejecución del supuesto incumplimiento del artículo 2 de la Convención Americana se produce cuando el Estado se obligó a adecuar su legislación interna a la Convención, es decir, al momento en que la ratificó. En otras palabras, la Corte no tiene competencia para declarar una presunta violación al artículo 2 de la Convención al momento en que dicho Decreto Ley fue promulgado (1978), ni respecto a su vigencia y aplicación hasta el 21 de agosto de 1990, porque hasta ese momento no existía el deber del Estado de adecuar su legislación interna a los estándares de la Convención Americana. No obstante, a partir de esa fecha rige para Chile tal obligación, y esta Corte es competente para declarar si la ha cumplido o no.

51. En consecuencia, se rechaza la excepción preliminar en los términos que se han señalado.

\section{SEgunda EXCEPCI ÓN Preli Mi naR: VI OLACI ONES DE TRÁMI TE ANTE LA COMISIÓN}

\section{Alegatos del Estado}

a) mediante nota de 11 de abril de 2005, la Comisión Interamericana comunicó al Estado que aprobó el Informe de Fondo No. 30/05 el 7 de marzo de 2005. En la misma nota se solicitó al Estado que informara, dentro del plazo de dos meses contados desde la fecha de su transmisión, sobre las medidas adoptadas para dar cumplimiento a las recomendaciones de la Comisión en dicho Informe;

b) el 15 de abril de 2005 el Estado solicitó la concesión de una prórroga al plazo otorgado, en virtud de que no se adjuntó en forma integra el Informe de Fondo a la nota de 11 de abril. El Informe íntegro fue recibido un mes después, el 12 de mayo de 2005. En estas circunstancias, el Estado quedó en una situación de desmedro respecto del término que dispuso para informar sobre las medidas de cumplimiento, cuyo vencimiento se mantuvo en los dos meses originales;

c) nuevamente, el 15 de junio de 2005, se insistió ante la Comisión en la concesión de una prórroga que reflejara que el Estado disponía de los tres meses que contempla el artículo 51 de la Convención, lo que no fue acogido; 
d) el Estado presentó el 11 de julio de 2005 a la Comisión su informe con las medidas adoptadas para dar cumplimiento a las recomendaciones contenidas en el Informe de Fondo No. 30/05, y así cumplió con informar dentro de plazo;

e) es dable suponer fundadamente que la demanda contra Chile fue redactada sin haber tenido a la vista, o al menos, sin haber considerado someramente, la comunicación de 11 de julio de 2005, sobre las medidas adoptadas para dar cumplimiento a las recomendaciones del Informe de Fondo $\mathrm{y}$, por consiguiente, que se habría vulnerado el derecho del Estado de Chile a ser oído;

f) con anterioridad a la fecha en que se comunicó al Estado la concesión de una prórroga para acompañar el informe de cumplimiento, ya se había tomado la decisión de elevar el caso al conocimiento de la Corte Interamericana y se habían solicitado los antecedentes, por correo electrónico, al representante de las presuntas víctimas, y

g) la decisión de la Comisión después de conocido el informe de cumplimiento estatal fue solicitar al Estado que manifieste su interés de someterse al procedimiento de solución amistosa que establecen los artículos 48.1.f de la Convención y 41 del Reglamento de la Comisión.

53. Alegatos de la Comisión

a) el 11 de abril de 2005, al transmitir al Estado el Informe adoptado en relación con el fondo del caso, la Comisión le otorgó plazo hasta el 11 de junio de 2005 para que informara sobre el cumplimiento de las recomendaciones formuladas;

b) el 24 de junio de 2005 el Estado solicitó a la Comisión que prorrogara el plazo hasta el 8 de julio de 2005. El 27 de junio de 2005 la Comisión otorgó al Estado plazo hasta el 1 de julio de 2005, para que se pronunciara sobre la implementación de las recomendaciones. Dicho plazo venció sin que se recibiese el informe estatal;

c) el correo electrónico del representante de la presunta víctima al que se refiere el Estado, contiene la respuesta del representante a la consulta formulada por la Comisión de conformidad con el artículo 43.3 de su Reglamento;

d) en ausencia de un informe estatal, el 11 de julio de 2005, último día del plazo establecido por el artículo 51.1 de la Convención, ante la falta de cumplimiento por parte del Estado de las recomendaciones del Informe de Fondo, la Comisión sometió el caso a la Corte, y

e) con posterioridad al sometimiento del caso ante la Corte, fue recibida una comunicación estatal en materia de cumplimiento, en que se expresó ánimo conciliatorio; el informe no acredita el cumplimiento de las recomendaciones formuladas, como se manifiesta en la contestación a la demanda, sino las razones por las cuales el Estado se considera imposibilitado de cumplirlas a plenitud, acompañadas de la reiteración de las diversas acciones emprendidas con el propósito de paliar la impunidad.

\section{Alegatos del Representante}


El representante no presentó alegatos en cuanto a la supuesta violación de procedimiento.

\section{Consideraciones de la Corte}

55. La segunda excepción preliminar del Estado se refiere a dos asuntos: i) el envío "apresurado" de la Comisión del presente caso a la Corte, sin que se hubiese tenido en cuenta el informe del Estado relativo al cumplimiento de las recomendaciones contenidas en el Informe de Fondo de la Comisión, y ii) que la decisión de la Comisión de someter el caso a la Corte se habría tomado con anterioridad a la presentación del informe estatal, puesto que se habrían solicitado "los antecedentes" al representante de las presuntas víctimas.

56. Respecto al primer argumento del Estado, resulta pertinente referirse a lo dispuesto en el artículo 51.1 de la Convención Americana:

Si en el plazo de tres meses, a partir de la remisión a los Estados interesados del informe de la Comisión, el asunto no ha sido solucionado o sometido a la decisión de la Corte por la Comisión o por el Estado interesado, aceptando su competencia, la Comisión podrá emitir, por mayoría absoluta de votos de sus miembros, su opinión y conclusiones sobre la cuestión sometida a su consideración.

57. Por su parte, el artículo 43 del Reglamento de la Comisión establece que:

Luego de la deliberación y voto sobre el fondo del caso, la Comisión procederá de la siguiente manera:

$[\ldots]$

2. Si establece una o más violaciones, preparará un informe preliminar con las proposiciones y recomendaciones que juzgue pertinentes y lo transmitirá al Estado en cuestión. En tal caso, fijará un plazo dentro del cual el Estado en cuestión deberá informar sobre las medidas adoptadas para cumplir las recomendaciones. El Estado no estará facultado para publicar el informe hasta que la Comisión adopte una decisión al respecto.

$[\ldots]$

58. Los plazos establecidos en los citados artículos no son los mismos. El plazo de tres meses señalado en el artículo 51.1 de la Convención es el plazo máximo dentro del cual la Comisión Interamericana está facultada para someter un caso a la competencia contenciosa de esta Corte, luego de lo cual la facultad de la Comisión caduca. Por su parte, el plazo del artículo 43.2 del Reglamento de la Comisión se refiere al plazo máximo dentro del cual un Estado debe informar a la Comisión sobre las medidas adoptadas para cumplir con sus recomendaciones. Este último plazo es fijado por la propia Comisión.

59. En el presente caso, no hay controversia entre las partes respecto a que la Comisión transmitió el Informe de Fondo No. 30/05 al Estado el 11 de abril de 2005, por medio de una comunicación que establecía como fecha máxima el 11 de junio de 2005, para que el Estado informara sobre las medidas adoptadas para cumplir las recomendaciones. Sin embargo, en esa fecha (11 de abril de 2005) el Estado no recibió el Informe No. 30/05 en forma íntegra. La versión completa del informe fue recibida por el Estado el 12 de mayo de 2005. Esto motivó que el 24 de junio de 2005 el Estado solicitara una prórroga al plazo establecido para presentar su informe de 
cumplimiento $^{11}$. El Estado sugirió que dicha prórroga se concediera hasta el 8 de julio de 2005. La Comisión Interamericana comunicó al Estado el 27 de junio de 2005 que concedía la prórroga solicitada hasta el 1 de julio de 2005. El Estado presentó su informe de cumplimento de las recomendaciones de la Comisión el 11 de julio de 2005.

60. Como puede apreciarse en el párrafo anterior, estaban transcurriendo dos plazos distintos, el plazo del Estado para presentar su informe de cumplimiento, que vencía el 1 de julio de 2005 (artículo 43.2 del Reglamento de la Comisión), y el plazo de la Comisión para someter el presente caso a la Corte, que vencía el 11 de julio de 2005 (artículo 51.1 de la Convención). Consecuentemente, el Estado erró al considerar que el plazo del artículo 51.1 de la Convención le era aplicable, cuando en realidad estaba sometido al plazo fijado por la Comisión en base al artículo 43.2 de su Reglamento.

61. Por tales razones, el Tribunal estima que el Estado presentó su informe de cumplimiento fuera de plazo, y que la Comisión actuó de conformidad con sus normas reglamentarias y la Convención Americana. El hecho de que el Informe No. 30/05 haya sido transmitido íntegramente al Estado el 12 de mayo 2005 no afecta la conclusión anterior, en vista de que la Comisión, teniendo en cuenta la transmisión tardía, otorgó un plazo adicional al Estado del 11 de junio al 1 de julio de 2005. Asimismo, la Corte estima que el hecho de que la Comisión haya consultado al Estado su interés en iniciar un proceso de solución amistosa el 17 de octubre de 2005, cuando el caso ya estaba en conocimiento de este Tribunal, si bien resulta incomprensible, no incide en la decisión de la Corte de considerar que el Estado presentó su informe de cumplimiento fuera de plazo.

62. En relación con el segundo argumento del Estado, respecto a que la Comisión habría tomado la decisión de someter el presente caso ante la Corte con anterioridad a la presentación del informe estatal, puesto que se habrían solicitado los antecedentes, por correo electrónico, al representante de las presuntas víctimas, la Corte nota que tal situación no se ha producido. En efecto, del expediente obrante ante este Tribunal se desprende que el correo electrónico al que hace referencia el Estado corresponde a la comunicación remitida a la Comisión el 24 de junio de 2005 por el representante de las presuntas víctimas, en el que envía la información solicitada por aquélla el 20 de junio de 2005, de conformidad con el artículo 43.3 del Reglamento de la Comisión, el cual dispone que:

Luego de la deliberación y voto sobre el fondo del caso, la Comisión procederá de la siguiente manera:

$[\ldots]$

3. Notificará al peticionario la adopción del informe y su transmisión al Estado. En el caso de los Estados partes en la Convención Americana que hubieran aceptado la jurisdicción contenciosa de la Corte Interamericana, al notificar al peticionario la Comisión dará a éste la oportunidad de presentar, dentro del plazo de un mes, su posición respecto del sometimiento del caso a la Corte. Si el peticionario tuviera interés en que el caso sea sometido a la Corte, deberá presentar los siguientes elementos:

a. la posición de la víctima o sus familiares, si fueran distintos del peticionario;

b. Ios datos de la víctima y sus familiares;

11 No consta en el expediente del presente caso obrante ante el Tribunal la supuesta solicitud de prórroga del Estado de 15 de abril de 2005 (supra párr. 52.b). 


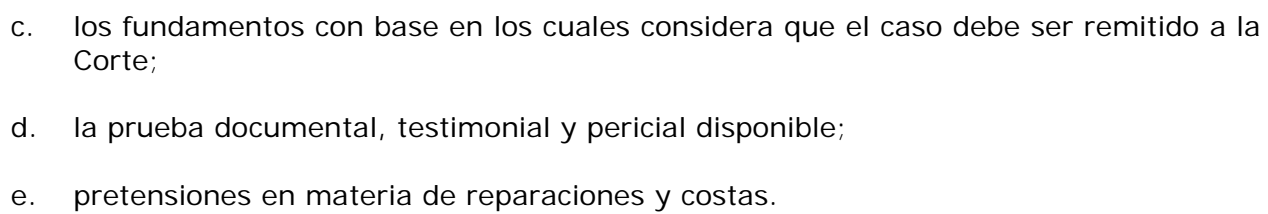

63. En virtud de las consideraciones expuestas, esta Corte decide desestimar la segunda excepción preliminar presentada por el Estado.

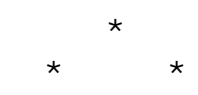

64. Este Tribunal observa que, si bien el Estado no ha planteado la excepción formal de no agotamiento de recursos internos, éste señaló, interalia, que "[I]os representantes de los familiares de la víctima, quienes tenían la calidad de querellantes particulares, no interpusieron los recursos de que disponían para llevar la definición de esta materia ante la Corte Suprema de Justicia de Chile". Al respecto, la Corte reitera los criterios sobre la interposición de la excepción de falta de agotamiento de los recursos internos, los que deben atenderse en el presente caso. En primer lugar, la Corte ha señalado que la falta de agotamiento de recursos es una cuestión de pura admisibilidad y que el Estado que la alega debe indicar los recursos internos que es preciso agotar, así como acreditar que esos recursos son efectivos. En segundo término, la excepción de no agotamiento de recursos internos debe plantearse, para que sea oportuna, en la etapa de admisibilidad del procedimiento ante la Comisión, o sea, antes de cualquier consideración en cuanto al fondo; si no es así, se presume que el Estado renuncia tácitamente a valerse de ella. En tercer lugar, el Estado demandado puede renunciar en forma expresa o tácita a la invocación de la falta de agotamiento de los recursos internos ${ }^{12}$.

65. En el caso particular, durante el procedimiento ante la Comisión el Estado no alegó la falta de agotamiento de los recursos internos (supra párr. 7). Por lo tanto, como consecuencia de no haber planteado en su oportunidad procesal objeción alguna sobre el agotamiento de los recursos internos, la Corte concluye que el Estado está impedido -en virtud del principio del estoppel- de hacerla prevalecer ante este Tribunal $^{13}$, porque ha renunciado tácitamente a ella. Consecuentemente, desestima el argumento estatal respecto a la falta de agotamiento de los recursos internos.

\section{VI \\ Prueba}

66. Antes del examen de las pruebas recibidas, la Corte realizará, a la luz de lo establecido en los artículos 44 y 45 del Reglamento, algunas consideraciones generales aplicables al caso específico, la mayoría de las cuales han sido desarrolladas por la propia jurisprudencia del Tribunal.

12 Cfr. Caso Acevedo Jaramillo y otros. Sentencia de 7 de febrero de 2006. Serie C No. 144, párr. 124.

13 Cfr. Caso Durand y Ugarte. Excepciones Preliminares. Sentencia de 28 de mayo de 1999. Serie C No. 50, párr. 38; Caso de la Comunidad Mayagna (Sumo) Awas Tingni. Excepciones Preliminares. Sentencia de 1 de febrero de 2000. Serie C No. 66, párrs. 56 y 57; y Caso Herrera Ulloa. Sentencia de 2 de julio de 2004. Serie C No. 107, párr. 83. 
67. En materia probatoria rige el principio del contradictorio, que respeta el derecho de defensa de las partes, siendo este principio uno de los fundamentos del artículo 44 del Reglamento, en lo que atañe a la oportunidad para el ofrecimiento de la prueba, con el fin de que haya igualdad entre las partes ${ }^{14}$.

68. Según la práctica del Tribunal, al inicio de cada etapa procesal las partes deben señalar qué pruebas ofrecerán en la primera oportunidad que se les concede para pronunciarse por escrito. Además, en ejercicio de las potestades discrecionales contempladas en el artículo 45 de su Reglamento, la Corte o su Presidente podrán solicitar a las partes elementos probatorios adicionales como prueba para mejor resolver, sin que ello se traduzca en una nueva oportunidad para ampliar o complementar los alegatos, salvo que el Tribunal lo permita expresamente ${ }^{15}$.

69. La Corte ha señalado anteriormente, en cuanto a la recepción y valoración de la prueba, que los procedimientos que se siguen ante ella no están sujetos a las mismas formalidades que las actuaciones judiciales internas, y que la incorporación de determinados elementos al acervo probatorio debe ser efectuada prestando particular atención a las circunstancias del caso concreto y teniendo presentes los límites trazados por el respeto a la seguridad jurídica y al equilibrio procesal de las partes. Además, la Corte ha tenido en cuenta que la jurisprudencia internacional, al considerar que los tribunales internacionales tienen la potestad de apreciar y valorar las pruebas según las reglas de la sana crítica, ha evitado siempre adoptar una rígida determinación del quantum de la prueba necesaria para fundar un fallo. Este criterio es especialmente válido en relación con los tribunales internacionales de derechos humanos, los cuales disponen, para efectos de la determinación de la responsabilidad internacional de un Estado por violación de derechos de la persona, de una amplia flexibilidad en la valoración de la prueba rendida ante ellos sobre los hechos pertinentes, de acuerdo con las reglas de la lógica y con base en la experiencia ${ }^{16}$.

70. Con fundamento en lo anterior, la Corte procederá a examinar y valorar los elementos probatorios documentales remitidos por la Comisión, los representantes y el Estado en diversas oportunidades procesales (supra párrs. 12, 15, 17, 19, 31, 33, 36 y 37), así como la prueba pericial y testimonial rendida ante la Corte durante la audiencia pública, todo lo cual conforma el acervo probatorio del presente caso. Para ello, el Tribunal se atendrá a los principios de la sana crítica, dentro del marco legal correspondiente.

\section{A) Prueba Documental}

71. En la prueba documental presentada por el Estado constan una declaración testimonial en respuesta a lo dispuesto por la Corte en su Resolución de 7 de febrero de 2006 (supra párr. 20) y un dictamen pericial de acuerdo a la Resolución del Presidente de la Corte de 24 de marzo de 2006 (supra párr. 27). Dichas declaraciones se resumen a continuación:

$14 \quad$ Cfr. Caso Ximenes Lopes. Sentencia de 4 de julio de 2006. Serie C No. 149, párr. 42; Caso de las Masacres de Ituango. Sentencia de 1 de julio de 2006. Serie C No. 148, párr. 106; y Caso Baldeón García. Sentencia de 6 de abril de 2006. Serie C No. 147, párr. 60.

15 Cfr. Caso Ximenes Lopes, supra nota 14, párr. 43; Caso de las Masacres de Ituango, supra nota 14, párr. 107; y Caso Baldeón García, supra nota 14, párr. 61.

16 Cfr. Caso Ximenes Lopes, supra nota 14, párr. 44; Caso de las Masacres de Ituango, supra nota 14, párr. 108; y Caso Baldeón García, supra nota 14, párr. 62. 
a) Declaración del señor Cristián Correa Montt, testigo propuesto por el Estado

El testigo declaró "sobre las medidas de reparación establecidas por el Estado de Chile a favor de las víctimas de violaciones a los derechos humanos cometidas por la dictadura de 1973 a 1990".

Según el testigo, como resultado final del trabajo de la Comisión Nacional de Verdad y Reconciliación, "ésta entregó un informe con antecedentes sobre cómo operaron las violaciones a los derechos humanos, incluyendo también un resumen de los principales antecedentes de todos los casos que quedaron con convicción y un listado de los casos pendientes".

Como parte de las recomendaciones de la Comisión de Verdad y Reconciliación y para implementar una política de reparación a las familias de las víctimas se creó la Corporación Nacional de Reparación y Reconciliación por la Ley 19.123 de 8 de febrero de 1992 (en adelante "la Ley 19.123"). Ésta "tuvo por objeto coordinar, ejecutar y promover las acciones necesarias para el cumplimiento de las recomendaciones contenidas en el Informe de la Comisión". La Ley 19.123, además, estableció otras medidas de reparación: una pensión de reparación, distinta según el tipo de parentesco con la víctima; beneficios médicos, es decir atención gratuita en establecimientos adscritos al Sistema Nacional de Servicios de Salud; para los hijos de las víctimas beneficios educacionales y la opción de quedar en la categoría de disponibles para los efectos del servicio Militar Obligatorio.

Al continuar el proceso de reconocimiento y reconciliación de las violaciones de derechos humanos, el Estado inició e implementó varias medidas de reparación como:

a) “Programa de Apoyo a los Presos Políticos que al 11 de marzo de 1990 se encontraban privados de la libertad" que proveía un apoyo económico para la reinserción y el acceso a indultos y/o conmutación de pena como medio para obtener la libertad;

b) “Programa de Reparación y Atención Integral de Salud (PRAIS) a los afectados por las violaciones a los derechos humanos";

c) “Corporación Nacional de Reparación y Reconciliación" que fue creada por la Ley No. 19.123 como la continuadora de la Comisión de Verdad y Reconciliación y tuvo por principal tarea el estudiar los 634 casos pendientes de su antecesora, estando también facultada para recibir nuevos casos;

d) "Programa de Derechos Humanos del Ministerio del Interior" que es el continuador de la Corporación de Reparación y Reconciliación y cuya principal tarea es la asesoría y la interposición de acciones judiciales para establecer las circunstancias del desaparecimiento y/o la muerte y la ubicación de los restos de las víctimas;

e) "Servicio Médico Legal" que trata de identificar los restos de detenidos desaparecidos;

f) "Oficina Nacional del Retorno" que fue creada por la Ley No. 18.994 y "atendió a personas que fueron condenadas y se les conmutó la pena por 
extrañamiento, en virtud del Decreto Supremo [No.] 504; personas expulsadas u obligadas a abandonar el país por resolución administrativa; personas que fueron objeto de prohibición de ingreso; personas que abandonaron el país por medio de asilo; personas que se acogieron al Estatuto de Refugiados de Naciones Unidas y obtuvieron refugio en otros países por razones humanitarias". Esta oficina "fue un centro de primera atención y de derivación a otros servicios públicos y a organismos no gubernamentales" y proveía "medidas administrativas y de reinserción";

g) "Programa Exonerados Políticos", mediante el cual el Estado consagró beneficios para quienes fueron exonerados por motivos políticos de la Administración Pública o de empresas del Estado o intervenidas por éste." Asimismo, fueron establecidos "como beneficios pensiones no contributivas de sobrevivencia y abono de tiempo de gracia";

h) “Restitución o Indemnización por Bienes Confiscados y Adquiridos por el Estado a través de los Decretos Leyes No. 12, 77 y 133 de 1973; No. 1.697 de 1977 y No. 2.346 de 1978";

i) "Mesa de Diálogo sobre Derechos Humanos", cuyo objetivo central era "avanzar en el esclarecimiento del destino final de los detenidos desparecidos";

j) “Iniciativa Presidencial 'No hay mañana sin ayer'” que fue iniciada para "seguir avanzando en el delicado proceso de sanar las heridas por las graves violaciones a los derechos humanos" incluyendo medidas tendientes a "perfeccionar la búsqueda de la verdad y la justicia", a "mejorar la reparación social a las víctimas" y a "fortalecer la sociedad y sus instituciones para que las violaciones a los derechos humanos no vuelvan a ocurrir", y

k) “Comisión Nacional sobre Prisión Política y Tortura" que fue creada en noviembre de 2003 como parte de la iniciativa presidencial señalada y estuvo orientada a "recabar antecedentes acerca de violaciones al derecho a la libertad personal y al derecho a la integridad y seguridad personales que se hubieren cometido por motivación política". Su objetivo era determinar "quiénes son las personas que sufrieron privación de libertad y torturas por razones políticas por actos de agentes del Estado o de personas a su servicio" y "proponer medidas de reparación".

En cuanto a las medidas que en particular han beneficiado a los familiares del señor Almonacid Arellano, el testigo señaló que todos los integrantes del núcleo familiar han tenido derecho a las medidas de reparación de salud señaladas anteriormente. "La cónyuge del señor Almonacid ha recibido la pensión [...]. Los hijos, a su vez, recibieron el bono [...]. En total, en los años de vigencia de estas medidas, la familia directa ha recibido transferencias [...] por una suma aproximada de US\$98 mil [dólares de los Estados Unidos de América]. Además, dos de los hijos hicieron uso del derecho consagrado por la Ley 19.123 de acceder a becas de estudio de educación superior. [...] En total, el grupo familiar recibió becas de estudios por la suma total de US\$12.180 [dólares de los Estados Unidas de América]".

El testigo concluyó que "el conjunto de todas estas medidas de reparación refleja la voluntad del Estado de reconocer las violaciones a los derechos humanos cometidas, incluyendo un reconocimiento individual de las víctimas y su significación, y de adoptar 
medidas que respondan a las diversas necesidades de reparación de éstas, en los ámbitos financiero, de salud, educación, vivienda y otros".

b) Dictamen del señor Cristian Maturana Miquel, perito propuesto por el Estado

Según el perito, “[a]l ratificar [la] Convención [Americana], y teniendo presente que la restauración del sistema democrático jamás es posible que se consolide de inmediato, sino que sólo en forma gradual y paulatina, se debió limitar la forma de entrada en vigencia de esa Convención mediante una Declaración por parte del Estado de Chile".

"La referida Declaración, que no constituye una reserva, impide que la Comisión y la Corte se avoquen al conocimiento de casos cuyos hechos hubieren tenido su principio de ejecución antes del 11 de marzo de 1990".

“Respecto de la primera recomendación [de la Comisión Interamericana,] consistente en establecer responsabilidades por la ejecución extrajudicial del señor Luis Alfredo Almonacid Arellano mediante un debido proceso judicial y una investigación completa e imparcial de los hechos, [...] requiere remontarse por parte del Estado a una situación anterior al 11 de marzo de 1990, y por ello, tanto la Comisión como la Corte Interamericana son incompetentes según la Declaración formulada por el Estado de Chile".

Lo mismo acontece por la segunda recomendación de la Comisión que consiste en "adecuar estas medidas legislativas u otras medidas, de manera que deje sin efecto el Decreto Ley No. 2.191, conocido como la ley de 'auto amnistía'" dado que "este Decreto Ley data del año 1978, y por ello se trata de un hecho que queda amparado por la Declaración formulada".

En cuanto a "la adecuación de la legislación interna a la normativa de los Derechos Humanos", el perito informó que Chile "ha ido en forma paulatina, pero sostenidamente, introduciendo importantes modificaciones con esa finalidad".

En cuanto a la jurisdicción penal militar el perito informó que "se ha reducido el ámbito de su competencia por la Ley No. 19.047, publicada en el Diario Oficial de 14 de febrero de 1991" y "se ha introducido a nivel de rango constitucional diversas modificaciones".

Por otro lado, el perito estimó que "la derogación o Declaración de nulidad de la ley de amnistía por la vía legislativa puede presentar mayores obstáculos jurídicos que el interpretar jurisprudencialmente que las normas internacionales deben ser preferidas por sobre las internas y que por ello deben primar en su aplicación [...]. En efecto, si se declara la derogación o nulidad de la ley de amnistía ello no solucionaría a lo menos en el plano interno la pugna con la norma de rango constitucional que obliga a aplicar la ley más favorable al reo y no establecer la incriminación o castigo de conductas con efecto retroactivo".

B) Prueba Testimonial y Pericial 
72. El 29 de marzo de 2006 la Corte recibió en audiencia pública las declaraciones de los testigos y peritos propuestos por las partes (supra párr. 28). El Tribunal procederá a resumir dichas declaraciones y dictámenes periciales a continuación.

\section{a) Declaración de Elvira Gómez Olivares, esposa de Luis Alfredo Almonacid Arellano, testigo propuesta por el representante}

Según la testigo, "el día 14 de septiembre [de 1973] llegó una patrulla a [su] casa buscando a [su] esposo que no se encontraba en ese momento. Allanaron [la] casa [...] y [le] encañonaron con [un] arma[. Ella t]enía un embarazo de ocho meses y medio. Registraron todo y se fueron".

“El día 16 [de septiembre de 1973], a las once de la mañana [su esposo] fue a la casa a ver[la], porque él no se encontraba alojando [allí] por razones de seguridad. [A eso de] las once y media de la mañana llegó una patrulla a buscarlo[.] Lo sacaron a empujones, no le dejaron ponerse el vestón y lo llevaron los carabineros [...]. Lo empujaban y él iba nervioso, con las manos en alto. [Su] marido usaba lentes. [Al llegar] a la esquina de la casa [...] en el tumulto [vio] que [su] marido trastabill[ó], trata[ba] de sujetar sus lentes que se le [caían] y [sintió] la ráfaga de la metralleta [...]. Eran dos carabineros que en ese momento iban con él. Cayó herido de muerte ya, pero quedó vivo y [la testigo] a socorrerlo, vacil[ó] y venía [su] hijo pequeño detrás de [ella], de dos años y se lo pasó a [su] hijo de nueve años que v[enía] atrás, para que se lo lleve a la casa". La testigo intentó acercarse al señor Almonacid, "pero la cara del teniente que estaba con él, con su metralleta [se] lo impidió y [ella se] par[ó] a dos metros de él en una muralla, a ver lo que hacían con [el señor Almonacid]. El sargento fue a buscar una camioneta. La trajeron. [...] Tomaron [al señor Almonacid] como un fardo de papas y lo tiraron arriba. Se subieron. Después llegaron varios carabineros más [...] y lo llevaron al hospital[.] Lo operaron, pero [...] murió ya al día siguiente".

“En el momento mismo que a [su] marido le dispararon, a [ella se le] desprendió la placenta y [su] hijo murió también". Después de la muerte del señor Almonacid Arellano su "familia completa fue destruida, porque [sus] hermanos quedaron sin trabajo, [su] hermano mayor, que era el sostén de la familia fue relegado, y [...] a [ella le] vigilaban eternamente todos los días".

Fue citada una vez por el Juzgado del Crimen, pero nunca a la Fiscalía Militar y nunca ha recibido alguna oferta del Consejo de Defensa del Estado de Chile para hacerse cargo judicialmente del caso. Rindió declaración ante la Comisión Nacional de Verdad y Reconciliación, y la reseña de la ejecución extrajudicial de su marido, junto con el nombre de éste, aparecen en el informe final de esa Comisión.

Desde 1992 recibe una pensión que proviene del Estado de Chile. Antes de percibir la pensión sobrevivió "cociendo, haciendo trabajos en [su] casa y con la ayuda solidaria de muchas personas que llegaron a ayudar[le] en ese momento". Lo que percibe actualmente, le alcanza para vivir "medianamente, porque [tiene] una salud muy mala". Dos de sus tres hijos han recibido becas y hoy día son profesionales. Además, usan la tarjeta de atención gratuita de salud, en el sistema público de salud. Ella no ha podido usarla porque su "salud está tan mala" que debe "recurr[ir] a lo que es más rápido, pero no porque no [le] sirva". Sin embargo, cree que "va a llegar el momento en que la [va] a necesitar y est[á] dispuesta a usarla". El nombre de su marido, como medida de reparación simbólica, se encuentra incluido en el memorial que se hizo a las víctimas de la represión de la dictadura militar en el cementerio general, además existe una calle y una villa denominada "Luis Almonacid" en la ciudad de Rancagua. 
De la Corte Interamericana espera que "se haga justicia, [...] se revindique la memoria de [su] marido, se abr[a] un juicio imparcial [...] y en la medida que [...] se haga justicia nunca nadie más vuelva a sufrir lo que [ella] sufrió". Además, señaló que desea que "se derogue [el Decreto] Ley No. 2.191 y se vea que la ley de amnistía no sirve".

\section{b) Declaración de J orge Correa Sutil, testigo propuesto por el Estado}

En su opinión, "las políticas del gobierno democrático, desde el año 1990 a la fecha, han estado fuertemente influidas por dos propósitos. Esto es, en primer lugar, la prevención de futuras violaciones de derechos humanos, y en segundo lugar, la reparación a las víctimas".

“Con ese propósito la primera gran medida [...] fue la creación de una Comisión Nacional de Verdad y Reconciliación [la cual hizo] una declaración explícita respecto de la calidad de víctimas de cada una de esas personas, las que fueron luego complementadas por una segunda comisión, la Corporación Nacional de Reparación y Reconciliación entre los años 92 y 96, llegando aproximadamente a la individualización de cerca de algo más de 3000 víctimas. Respecto de cada una de ellas el Estado de Chile a través del poder legislativo declaró solemnemente su derecho a conocer la verdad de lo ocurrido y a conocer la suerte de los detenidos-desaparecidos y los ejecutados sin la entrega de restos y proveyó una serie de medidas de reparación al respecto. Talvez lo más importante fue la publicación del Informe [ de la Comisión de la Verdad] que significó de alguna manera colocar en la opinión la posibilidad de un repudio social respecto de hechos que habían sido negados o distorsionados gravemente por el Gobierno militar, como era precisamente el caso de los muertos y desaparecidos. Se reivindicó o se hizo el intento de reivindicar de alguna manera el buen nombre de aquellos que habían muerto o desaparecido, con acusaciones de que eran terroristas, o habían escapado del país". "Respecto de cada uno de ellos, se establecieron también medidas de reparación consistentes en pensiones periódicas a sus viudas, a sus familiares [...] se les otorgaron becas de estudio, y se proveyeron otra serie de medidas de carácter de salud y de exención del servicio militar obligatorio, una carga común en el país, respecto de los hijos de estos familiares. Se estableció también la obligación del Estado de propender a la memoria de estos casos a través de memoriales o formas de recuerdo de lo ocurrido precisamente para poder canalizar el repudio social".

“El Estado continúa adelante con esa política de reparación y [...] una segunda oleada de actividad gubernamental vino fuertemente a raíz de [...] algunos casos judiciales emblemáticos, [en particular el] encarcelamiento del General Contreras quien había sido el jefe de la Policía Secreta en Chile [...] y la detención del General Pinochet en Londres". Esos casos volvieron a "despertar en el país una conciencia fuerte respecto de la deuda todavía pendiente en materia de derechos humanos y fue el momento a través de la llamada Mesa de diálogo[,] un segundo hito de este trabajo. Un momento de reconocimiento por parte de las Fuerzas Armadas [...] el reconocimiento del mal causado y por lo tanto esta verdad de las más graves violaciones a los derechos humanos no solo fue conocido sino también, [...] por primera vez en Chile es reconocida por parte de sus autores".

"Un tercer momento de actividad gubernamental [...] se encuentra ubicado en el año 2003. [Este año] vuelve a producirse a raíz de hechos más bien políticos, un debate en el país respecto de lo realizado en materia de derechos humanos y el Gobierno vuelve 
a tomar la iniciativa para establecer luego una Comisión [Nacional sobre prisión Política y Tortura, con] una política pública para enfrentar nuevamente este tema. En primer lugar y de manera más importante, a través de la creación de una Comisión conocida popularmente como Comisión Valech, por quien la presidió, [a la que] correspondió hacer una tarea análoga a la que había hecho la Comisión Nacional de Verdad y Reconciliación, pero ahora respecto de las personas que habían sufrido o padecido de prisión política y tortura[... H]izo también un relato de carácter general y luego calificó, poco menos de 30.000 casos [...] como personas que habían padecido injustamente prisión política o tortura. Respecto de cada uno de ellos también el Congreso Nacional a partir de la iniciativa del Presidente Lagos estableció una pensión de reparación [...]".

El testigo calificó esa política de reparación como eficaz, señalando que "ha sido una política implementada: lo que el Estado o el Gobierno ha prometido se ha podido cumplir. Ha sido una política legítima socialmente, en el sentido de que no es una política que esté bajo fuego o que esté bajo discusión. Los propios familiares de las víctimas la han aceptado [...] como efecto del reconocimiento del agravio causado".

Además, la calificó como "una política de reparación incremental", porque ha ido abarcando "cada vez más víctimas, aumentando en algunos períodos las reparaciones monetarias, crecientemente estableciendo hitos y momentos de recuerdo de esas víctimas con un grado importante de aceptación social".

“El Gobierno como tal nunca patrocinó ningún proyecto de Ley para derogar el Decreto Ley de Amnistía. Lo hicieron varios parlamentarios de la coalición de gobierno. [Esta] era más bien una actividad testimonial o política en el sentido de crear conciencia ciudadana" porque no tuvieron la mayoría, ni la han tenido hasta hoy en día. "Hoy han cambiado por primera vez las fuerzas políticas para derogar el Decreto Ley de Amnistía". "Nadie ha[bía] pensado en la posibilidad de declarar inválida la ley porque eso no está en la tradición, [...] nunca el Congreso ha declarado la invalidación", y "el Tribunal Constitucional tiene ahora la facultad también de declarar la ley inválida" con requisitos más altos.

“Los argumentos para invalidar [el Decreto Ley de Amnistía] han estado fuertemente centrados en la inmoralidad de [éste], dictado por los propios autores de los crímenes". Es una inmoralidad que "por la vía jurídica se manifiesta fundamentalmente en la violación de principios del derecho internacional ya bastante asentados, por lo menos respecto de los crímenes más graves cometidos en lesa humanidad".

Los argumentos de la posición opuesta, o sea, para la validez del Decreto Ley de Amnistía son los siguientes: Primero, "si se consideraran inválidas las normas dictadas por los gobiernos de facto en Chile, buena parte [del] ordenamiento jurídico caería, incluyendo muchas de las normas que le otorgan legitimidad al actual sistema político. [...] Lo segundo es que éste es un Decreto Ley que se argumenta produjo pacificación en el país, que fue en su momento aplaudido [entre otros] por la Iglesia Católica [y que] fue un momento [...] de término de la [...] de la represión en Chile". "Tercero, ha habido una aplicación de este Decreto Ley de Amnistía que ha beneficiado a muchas personas".

c) Dictamen de Humberto Raúl I gnacio Nogueira Alcala, perito propuesto por la Comisión 
Según el perito, durante el período del régimen militar la Corte Suprema de Chile fue una "corte adicta al régimen autoritario militar". En el "período que va entre 1990 hasta septiembre de 1998 la regla general e[ra] la aplicación del Decreto [Ley] de Amnistía tan pronto como se adv[ertía] que el hecho investigado rev[estía] el carácter de delito comprendido en el período [que cubre el] Decreto [...], aplicándose [...] de pleno derecho".

“En septiembre de 1998 se abre una segunda etapa [...] con el caso Poblete y Córdoba, que determina que para aplicar la amnistía debe haberse investigado y determinado [al responsable] en forma indubitable, como única manera de extinguir la pena. Esta segunda etapa no dice que se va a sancionar, sino que el [Decreto] Ley de Amnistía se aplicará al momento de determinar la [identidad] del responsable. Por lo tanto [el] responsable no será sancionad[o]".

“El 7 de enero de 1999 en la causa contra Gómez Segovia [...] en caso de detenidosdesaparecidos calificados generalmente como secuestro calificado o como detención ilegal, se señala en este sentido que no corresponde aplicar el Decreto Ley de Amnistía en la medida en que el secuestro calificado o la detención ilegal constituye un delito permanente, y como delito permanente sí trasciende el período comprendido en la amnistía [...]. En definitiva, la amnistía no puede ser aplicada porque se trata de un delito que permanece en el tiempo".

“La sentencia de la Sala Penal de la Corte Suprema del 17 de noviembre de 2004 [...] va a confirmar una sentencia ya dictada por la Corte de Apelaciones donde además de mantener la tesis del secuestro permanente, agrega un elemento muy trascendente [...] que es la aplicación y el reconocimiento por primera vez de los Convenios de Ginebra de 1948, [y] reconoce explícitamente que había un estado de guerra en el año 1973, período donde ocurren también los [presentes] hechos".

“En una sentencia de la Sala Penal de 4 de agosto de 2005, [...] en el caso del Coronel Rivera [...] revoca la Sala Penal de la Corte Suprema la sentencia dictada por la Corte de Apelaciones de Temuco que acoge el derecho internacional utilizando el Pacto Internacional de Derechos Civiles y Políticos, [...] la Convención Americana [sobre] Derechos Humanos, la Declaración Americana de Derechos y Deberes del Hombre, y al mismo tiempo el derecho consuetudinario y los principios de jus cogens". En este caso "la Sala Penal de la Corte Suprema vuelve sobre sus pasos y dice que no ha[bía] estado de guerra en Chile [y] sostiene, por lo tanto, que no son aplicables los Convenios de Ginebra [...], que además no es aplicable [...] el Pacto Internacional de Derechos Civiles y Políticos, no porque no estuviera ratificado, sino simplemente por el hecho de no estar publicado en el Diario Oficial [...]. Es una forma de interpretación que tiene por objeto en el fondo tener una posición contraria a hacer justicia realmente en el caso. [A]nalizado todo el período [...] los casos en que [la Corte Suprema] ha sancionado es porque en definitiva se entiende que el delito ha sido más allá del período del Decreto Ley de Amnistía [...], pero siempre ha sostenido [que] si el caso cae dentro del período comprendido por el Decreto Ley de Amnistía, se aplica [éste]". "Los tribunales de justicia como órgano del Estado de Chile en definitiva han siempre aplicado preferentemente el Decreto Ley de Amnistía sobre el derecho internacional". "Las Cortes de Apelaciones y los tribunales de primera instancia a partir de 1994 inician un proceso que cada vez [...] desarrolla más [la] aplicación directa del derecho internacional".

“El tema no es solamente el Decreto Ley de Amnistía sino también de la prescripción ante delitos de lesa humanidad o delitos de crímenes de guerra, porque normalmente 
la Corte cada vez aplica menos el Decreto Ley [...] y empieza a aplicar cada vez más la prescripción de la acción penal".

d) Dictamen de Jean Pierre Matus Acuña, perito propuesto por el Estado de Chile

Según el perito, durante los primeros años de vigencia de la Convención Americana "y hasta entrado 1998 [...] la jurisprudencia de la Corte Suprema en la mayor parte de los casos sometidos a su conocimiento daba aplicaciones restrictas al Decreto Ley No. 2.191 de autoamnistía, señalando que el objetivo preciso de este Decreto Ley era impedir que se investigasen hechos [...], para mantener la paz social según los términos del propio Decreto Ley. Sin embargo, esta jurisprudencia no era uniforme aún en esa época y cambió significativamente durante el año 1998 en el sentido de, por una vía o por otra, no dar aplicación al Decreto Ley [No.] 2.191, o sea, mediante artilugios procesales que han permitido llevar adelante las investigaciones judiciales, determinar los hechos investigados e identificar y sancionar a los responsables, sea reconociendo [...] la incompatibilidad de este Decreto Ley con el ordenamiento democrático y los tratados de derechos humanos vigentes en Chile". En efecto, en una sentencia del 30 de septiembre de 1994, "se sentaron las bases jurídicas para dejar sin aplicación el Decreto Ley de Amnistía en el ordenamiento chileno". "Según los considerandos principales de esta sentencia, la jurisprudencia de los tribunales superiores de justicia en Chile se ha ido asentando en el sentido de dar primacía a los Tratados sobre la ley interna[.] [E]n materia de derechos humanos el juez debe interpretar los Tratados teniendo en cuenta su fin último, que es la protección a los derechos de la persona humana". "Existe así una plena armonía entre el derecho convencional vigente en Chile en materia de derechos humanos y la Carta fundamental agregando que en tal sentido las leyes valen en la medida que se respeten y se garanticen los derechos humanos, por lo que concluye que los delitos de secuestrodesaparición que constituyen violaciones graves de la Convención de Ginebra no son sujetos a amnistía según el ordenamiento interno chileno".

“Lamentablemente, en ese momento, el criterio jurisprudencial dominante en la Corte Suprema daba aplicación más o menos irrestricta al Decreto Ley de Amnistía, por lo cual este fallo fue revocado el 26 de octubre de 1995 y posteriormente la causa fue sobreseída el 19 de agosto de 1998, justo antes de que comenzara el cambio jurisprudencial".

“En efecto, si uno revisa la jurisprudencia sobre amnistía [...] podrá comprobarse que explícita e implícitamente la Corte Suprema ha denegado de hecho y de derecho la aplicación del Decreto Ley de Amnistía [No.] 2191 en los casos de más graves violaciones de derechos ocurridas en Chile durante la dictadura militar. Aisladamente, a partir del año 90, pero de manera creciente y sistemática, desde el año 1998".

"Siguiendo esta tendencia jurisprudencial ya sentada en la Corte Suprema, 300 sentencias de la Corte de Apelaciones de Santiago han comenzado a condenar a los autores de graves violaciones de derechos humanos, dejando de hecho y de derecho sin aplicación el Decreto Ley de Amnistía.

A su juicio, "lo que existe en Chile [...] es un papel escrito en el cual consta una resolución dictada por el gobierno de facto, con un número y unos considerandos que le llamamos Decreto Ley de Amnistía, pero como norma vigente en Chile [...] prácticamente no existe, puesto que los tribunales sistemáticamente no lo aplican". 


\section{C) Valoración de la Prueba}

73. En este apartado la Corte se pronunciará sobre la valoración de los elementos probatorios aportados al Tribunal.

74. En este caso, como en otros ${ }^{17}$, el Tribunal admite el valor probatorio de aquellos documentos presentados por las partes en su oportunidad procesal que no fueron controvertidos ni objetados, ni cuya autenticidad fue puesta en duda.

75. Respecto a la declaración rendida por el señor Cristián Correa Montt (supra párr. 21), este Tribunal la admite en cuanto concuerde con su objeto, señalado en la Resolución de la Corte de 7 de febrero de 2006 (supra párr. 20), teniendo en cuenta las observaciones del representante (supra párr. 24) y de la Comisión (supra párr. 26). Asimismo, acepta los documentos presentados por el señor Correa Montt junto con su declaración y los valora en el conjunto del acervo probatorio y con aplicación de las reglas de la sana crítica.

76. En lo que respecta a la declaración del perito Cristián Maturana Miquel (supra párr. 29), este Tribunal comparte lo indicado por la Comisión Interamericana (supra párr. 32), en el sentido de que tal declaración contiene pronunciamientos del perito ajenos al objeto para el que fue solicitada por Resolución del Presidente de 24 de marzo de 2006 (supra párr. 27). No obstante lo anterior, la admite pues la considera útil para la presente causa, y la valora en el conjunto del acervo probatorio y con aplicación de las reglas de la sana crítica, teniendo en cuenta las observaciones de la Comisión, y las observaciones que al respecto presentó el Estado (supra párr. 37).

77. Si bien las dos declaraciones señaladas en los párrafos anteriores fueron presentadas ante un notario público para el reconocimiento de la firma de sus autores $y$, por tanto, no constituyen formalmente affidávits, el Tribunal las acepta, en vista de que no se ha afectado la seguridad jurídica ni el equilibrio procesal entre las partes.

78. En relación con las declaraciones rendidas en la audiencia pública por el testigo Jorge Correa Sutil y por los peritos Raúl I gnacio Nogueira Alcala y Jean Pierre Matus Acuña, la Corte las admite en cuanto concuerden con el objeto establecido mediante Resoluciones de 7 de febrero (supra párr. 20) y 24 de marzo de 2006 (supra párr. 27), y les reconoce valor probatorio. Este Tribunal estima que el testimonio de la señora Elvira Gómez Olivares (supra párrs. 28), que resulta útil en el presente caso, no puede ser valorado aisladamente por tratarse de una presunta víctima y tener un interés directo en este caso, sino debe serlo dentro del conjunto de las pruebas del proceso ${ }^{18}$. Asimismo, respecto a la documentación presentada por los peritos Raúl Ignacio Nogueira Alcala y Jean Pierre Matus Acuña durante la audiencia pública del presente caso (supra párr. 28), la Corte decide admitirla, por cuanto resulta útil para el presente caso y porque forma parte de la fundamentación de los referidos peritajes.

79. En lo que respecta a la prueba documental remitida por las partes con posterioridad a la presentación de sus escritos principales (supra párr. 19, 31, 33, 36 y 37), sólo la Comisión Interamericana presentó objeciones, relativas únicamente a la

17 Cfr. Caso Ximenes Lopes, supra nota 14, párr. 48; Caso de las Masacres de Ituango, supra nota 14, párr. 112; y Caso Baldeón García, supra nota 14, párr. 65.

18 Cfr. Caso Ximenes Lopes, supra nota 14, párr. 48; Caso de las Masacres de Ituango, supra nota 14, párr. 121; y Caso Baldeón García, supra nota 14, párr. 66. 
prueba remitida por el Estado junto con sus alegatos finales (supra párr. 34). El resto de la documentación aportada por las partes no fue objetada por ninguna de ellas. La Corte nota que parte de la prueba presentada por el Estado junto con sus alegatos finales escritos corresponde a la prueba solicitada por la Corte en la audiencia pública del presente caso (supra párr. 28), por lo cual decide aceptarla. Respecto al resto de la prueba remitida por las partes, este Tribunal igualmente decide admitirla, puesto que la considera útil para la resolución de este caso. Por lo tanto, agrega toda esta documentación al acervo probatorio.

80. Respecto a la documentación remitida por la Asociación Americana de Juristas de Valparaíso/Aconcagua, en calidad de anexos a su amicus curiae, la Corte la admite, por cuanto contiene información útil y relevante para el presente caso.

81. Finalmente, en cuanto a los documentos de prensa presentados por las partes, este Tribunal ha considerado que podrían ser apreciados cuando recojan hechos públicos y notorios o declaraciones de funcionarios del Estado, o cuando corroboren aspectos relacionados con el caso ${ }^{19}$.

\section{VII \\ Hechos Probados}

82. Después de analizados los elementos probatorios, las declaraciones de testigos y peritos, así como los alegatos de la Comisión Interamericana, los representantes y el Estado, la Corte considera probados los hechos que se detallan a continuación. Resulta importante resaltar que el Estado no contradijo en ningún momento procesal los hechos señalados en los numerales 1 a 23 de este capítulo. De igual forma, la Comisión y los representantes no contradijeron los hechos que se detallan en los numerales 24 y 26 a 35 de este capítulo. Por otro lado, la Corte desea precisar que los hechos descritos en el literal b) infra, relativos a lo ocurrido con anterioridad a la fecha de ratificación de la competencia de la Corte por parte de Chile, únicamente sirven como antecedentes para contextualizar los hechos señalados en los literales siguientes ${ }^{20}$. Finalmente, la Corte resalta que los hechos contenidos en el literal b.i) fueron obtenidos en su totalidad de los tres informes oficiales sobre los sucesos ocurridos entre el 11 de septiembre de 1973 al 10 de marzo de 1990, a saber, el Informe de la Comisión Nacional de Verdad y Reconciliación, el Informe sobre calificación de víctimas de violaciones de derechos humanos y de la violencia política de la Corporación Nacional de Reparación y Reconciliación, y el Informe de la Comisión Nacional sobre prisión política y tortura.

a) Sobre el señor Almonacid Arellano, la señora Gómez Olivares y los hijos de ambos

19 Cfr. Caso Ximenes Lopes, supra nota 14, párr. 55; Caso de las Masacres de Ituango, supra nota 17, párr. 122; y Caso Baldeón García, supra nota 14, párr. 70.

20 Como lo ha expresado la Corte Europea, aunque sólo se tenga competencia temporal en relación con hechos posteriores a la ratificación del Convenio Europeo, "puede, sin embargo, tomar en consideración los hechos anteriores a la ratificación, en la medida en que [...] pudieran ser relevante para la comprensión de los hechos ocurridos luego de tal fecha". ECHR, Case Broniowski v Poland [GC]. Judgment of 22 June 2004, Application nos. 31433/96, para. 122. 
82.1. El señor Luis Alfredo Almonacid Arellano y la señora Elvira del Rosario Gómez Olivares estaban casados entre sí $^{21}$, y tuvieron tres hijos, los señores Alfredo, Alexis y José Luis Almonacid Gómez.

82.2. El señor Almonacid Arellano “era profesor de enseñanza básica, militante del Partido Comunista, candidato a regidor del mismo partido, secretario provincial de la Central Unitaria de Trabajadores y dirigente gremial del Magisterio (SUTE)"22.

b) Antecedentes: hechos ocurridos antes del 21 de agosto de 1990

\section{i) Contexto}

82.3. El 11 de septiembre de 1973 advino en Chile un régimen militar que derrocó al Gobierno del Presidente Salvador Allende. "Los institutos armados y de orden, a través de la Junta de Gobierno, asumieron primero el poder ejecutivo (Decreto Ley No. 1) y luego el constituyente y el legislativo (Decreto Ley No. 128)"23. La nueva Presidencia de la República/Comandancia en Jefe estuvo dotada "de una suma de poderes jamás vista en Chile. Su titular no sólo gobernaba y administraba el país, sino que además integraba y presidía la J unta de Gobierno -y, por ende, no se podía legislar ni reformar la Constitución sin él- y comandaba todo el Ejército" ${ }^{24}$. Mediante Decreto Ley No. 5 de 22 de septiembre de 1973 "se declaró que el estado de sitio por conmoción interna que regía al país debía entenderse como `estado o tiempo de guerra'"'25.

82.4. La represión generalizada dirigida a las personas que el régimen consideraba como opositoras (infra párr. 82.6), como política de Estado, operó desde ese mismo día hasta el fin del gobierno militar el 10 de marzo de 1990, "aunque con grados de intensidad variables y con distintos niveles de selectividad ${ }^{26}$ a la hora de señalar a sus víctimas"27. Esta represión estuvo caracterizada por una práctica masiva y sistemática $^{28}$ de fusilamientos y ejecuciones sumarias, torturas (incluida la violación sexual, principalmente de mujeres), privaciones arbitrarias de la libertad en recintos al

21 Cfr. certificado de matrimonio conferido por el Registro Civil y de Identificación de Rancagua, (expediente de anexos a los alegatos finales escritos del Estado, Anexo 1, folio 1675).

22 Cfr. Informe de la Comisión Nacional de Verdad y Reconciliación, Tomo III, pág. 18, (expediente de anexos a los alegatos finales escritos del Estado, Anexo 2, folio 2572).

23 Cfr. Informe de la Comisión Nacional de Verdad y Reconciliación, Tomo I, pág. 42, (expediente de anexos a los alegatos finales escritos del Estado, Anexo 2, folio 2101).

24 Cfr. Informe de la Comisión Nacional de Verdad y Reconciliación, Tomo I, pág. 47, (expediente de anexos a los alegatos finales escritos del Estado, Anexo 2, folio 2103).

25 Cfr. Informe de la Comisión Nacional de Verdad y Reconciliación, Tomo I, pág. 60, (expediente de anexos a los alegatos finales escritos del Estado, Anexo 2, folio 2110).

26 Cfr. Informe de la Comisión Nacional de Verdad y Reconciliación, Tomo I, pág. 115, (expediente de anexos a los alegatos finales escritos del Estado, Anexo 2, folio 2137).

27 Cfr. Informe de la Comisión Nacional sobre prisión política y tortura, pág. 177 (expediente de anexos a los alegatos finales escritos del Estado, Anexo 4, folio 3583).

28 Cfr. Informe de la Comisión Nacional de Verdad y Reconciliación, Primera Parte, capitulo II y Segunda Parte, Págs. 15 a 104 (expediente de anexos a los alegatos finales escritos del Estado, Anexo 2); e Informe sobre calificación de víctimas de violaciones de derechos humanos y de la violencia política de la Corporación Nacional de Reparación y Reconciliación, pág. 37 (expediente de anexos a los alegatos finales escritos del Estado, Anexo 3, folio 2822). 
margen del escrutinio de la ley, desapariciones forzadas, y demás violaciones a los derechos humanos cometidas por agentes del Estado, asistidos a veces por civiles. La represión se aplicó en casi todas las regiones del país ${ }^{29}$.

82.5. La época más violenta de todo el período represivo corresponde a los primeros meses del gobierno de facto. De las $3.197^{30}$ víctimas identificadas de ejecuciones y desapariciones forzadas que ocurrieron en todo el gobierno militar, 1.823 se produjeron en el año $1973^{31}$. Por su parte, "el $61 \%$ de las 33.221 detenciones que fueron calificadas por la Comisión Nacional sobre Prisión Política y Tortura, corresponde a detenciones efectuadas en 1973"32. Esta misma Comisión señaló que "más del 94\% de las personas que sufrieron prisión política" dijeron haber sido torturadas por agentes estatales ${ }^{33}$.

82.6. Las víctimas de todas estas violaciones fueron funcionarios destacados del régimen depuesto y connotadas figuras de izquierda, así como sus militantes comunes y corrientes; jefes y dirigentes políticos, sindicales, vecinales, estudiantiles (de enseñanza superior y media) e indígenas; representantes de organizaciones de base con participación en movimientos de reivindicaciones sociales. "Muchas veces [las] relaciones políticas se deducían de la conducta 'conflictiva' de la víctima en huelgas, paros, tomas de terrenos o de predios, manifestaciones callejeras, etc." 34 . Las ejecuciones de estas personas "se insertan dentro del clima reinante [...] de hacer una 'limpieza' de elementos juzgados perniciosos por sus doctrinas y actuaciones, y de atemorizar a sus compañeros que podían constituir una eventual 'amenaza'"35. No obstante, en la época inicial de la represión existió un amplio margen de arbitrariedad a la hora de seleccionar a las víctimas ${ }^{36}$.

29 Cfr. Informe de la Comisión Nacional de Verdad y Reconciliación, pág. 19 (expediente de anexos a los alegatos finales escritos del Estado, Anexo 2, folio 2089); Informe sobre calificación de víctimas de violaciones de derechos humanos y de la violencia política de la Corporación Nacional de Reparación y Reconciliación (expediente de anexos a los alegatos finales escritos del Estado, Anexo 3); e Informe de la Comisión Nacional sobre prisión política y tortura (expediente de anexos a los alegatos finales escritos del Estado, Anexo 4).

30 Cfr. cuadro 16 "Víctimas declaradas por el Estado, Clasificadas como muertas y desaparecidas", anexo 1 del Informe sobre calificación de víctimas de violaciones de derechos humanos y de la violencia política de la Corporación Nacional de Reparación y Reconciliación, pág. 576 (expediente de anexos a los alegatos finales escritos del Estado, Anexo 3, folio 3356).

$31 \quad$ Cfr. cuadro 17 "Denuncias investigadas y víctimas declaradas por el Estado, según el año en que ocurrieron los hechos denunciados", Anexo 1 del Informe sobre calificación de víctimas de violaciones de derechos humanos y de la violencia política de la Corporación Nacional de Reparación y Reconciliación, pág. 577, (expediente de anexos a los alegatos finales escritos del Estado, Anexo 3, folio 3357).

32 Cfr. Informe de la Comisión Nacional sobre Prisión Política y Tortura, pág. 178 (expediente de anexos a los alegatos finales escritos del Estado, Anexo 4, folio 3584).

33 Cfr. Informe de la Comisión Nacional sobre Prisión Política y Tortura, pág. 177, (expediente de anexos a los alegatos finales escritos del Estado, Anexo 4, folio 3583).

34 Cfr. Informe de la Comisión Nacional de Verdad y Reconciliación, Tomo I, pág. 114, (expediente de anexos a los alegatos finales escritos del Estado, Anexo 2, folio 2137).

35 Cfr. Informe de la Comisión Nacional de Verdad y Reconciliación, Tomo I, pág. 115, (expediente de anexos a los alegatos finales escritos del Estado, Anexo 2, folio 2137).

36 Cfr. Informe de la Comisión Nacional de Verdad y Reconciliación, (expediente de anexos a los alegatos finales escritos del Estado, Anexo 2); Informe sobre calificación de víctimas de violaciones de derechos humanos y de la violencia política de la Corporación Nacional de Reparación y Reconciliación, (expediente de anexos a los alegatos finales escritos del Estado, Anexo 3); e Informe de la Comisión 
82.7. En lo que se refiere a las ejecuciones extrajudiciales - crimen cometido en el presente caso-, "[p]or lo general, las muertes fueron de personas detenidas y se practicaban en lugares apartados y de noche. Algunos de los fusilamientos al margen de todo proceso fueron, sin embargo, fulminantes y se efectuaron al momento de la detención. [...] En las regiones del sur [del país] la persona, sometida ya al control de sus captores, [era] ejecutada en presencia de su familia" ${ }^{37}$.

\section{ii) La ejecución del señor Almonacid Arellano y la iniciación del procedimiento penal seguido por ese hecho}

82.8. “El día 16 de septiembre de 1973 fue detenido [el señor Almonacid Arellano, de 42 años de edad,] en su domicilio ubicado en la población Manso de Velasco, por carabineros, quienes le dispararon, en presencia de su familia, a la salida de su casa. Falleció en el Hospital Regional de Rancagua el día 17 de septiembre de 1973"38.

82.9. El 3 de octubre de 1973 el Primer Juzgado del Crimen de Rancagua inició una investigación bajo la causa No. 40.184 por la muerte del señor Almonacid Arellano ${ }^{39}$, la cual fue sobreseída por este Juzgado el 7 de noviembre de $1973^{40}$. La Corte de Apelaciones de Rancagua revocó tal sobreseimiento el 7 de diciembre de $1973^{41}$. Desde esa fecha en adelante el caso fue sobreseído una y otra vez por el Juzgado del Crimen $^{42}$, mientras que la Corte de Apelaciones continuó revocando tales sobreseimientos $^{43}$, hasta que el 4 de septiembre de 1974 confirmó el sobreseimiento temporal de la causa ${ }^{44}$.

iii) El Decreto Ley No. 2.191

82.10. El 18 de abril de 1978 el gobierno de facto que regía en el país dictó el Decreto Ley No. 2.191, mediante el cual concedió amnistía en los siguientes términos:

Nacional sobre prisión política y tortura, (expediente de anexos a los alegatos finales escritos del Estado, Anexo 4).

37 Cfr. Informe de la Comisión Nacional de Verdad y Reconciliación, Tomo I, pág. 117, (expediente de anexos a los alegatos finales escritos del Estado, Anexo 2, folio 2138).

$38 \quad$ Cfr. Informe de la Comisión Nacional de Verdad y Reconciliación, Tomo III, pág. 18, (expediente de anexos a los alegatos finales escritos del Estado, Anexo 2, folio 2572).

39 Cfr. providencia del Primer Juzgado del Crimen de Rancagua de 3 de octubre de 1973, (expediente de anexos a los alegatos finales escritos del Estado, Anexo 1, folio 1628).

40 Cfr. resolución del Primer Juzgado del Crimen de Rancagua de 7 de noviembre de 1973, (expediente de anexos a los alegatos finales escritos del Estado, Anexo 1, folio 1631).

41 Cfr. resolución de la Corte de Apelaciones de Rancagua de 7 de diciembre de 1973, (expediente de anexos a los alegatos finales escritos del Estado, Anexo 1, folio 1634).

42 Cfr. resoluciones del Primer Juzgado del Crimen de Rancagua de 8 de abril (expediente de anexos a los alegatos finales escritos del Estado, Anexo 1, folio 1631), 17 de mayo (expediente de anexos a los alegatos finales escritos del Estado, Anexo 1, folio 1658), y de 7 de agosto de 1974 (expediente de anexos a los alegatos finales escritos del Estado, Anexo 1, folio 1666).

$43 \quad$ Cfr. resoluciones de la Corte de Apelaciones de Rancagua de 30 de abril y 18 de junio de 1974 (expediente de anexos a los alegatos finales escritos del Estado, Anexo 1, folios 1655 y 1661).

$44 \quad$ Cfr. resolución de la Corte de Apelaciones de Rancagua de 4 de septiembre de 1974 (expediente de anexos a los alegatos finales escritos del Estado, Anexo 1, folio 1669). 


\section{Considerando:}

$1^{\circ}$ - La tranquilidad general, la paz y el orden de que disfruta actualmente todo el país, en términos tales, que la conmoción interna ha sido superada, haciendo posible poner fin al Estado de Sitio y al toque de queda en todo el territorio nacional;

$2^{\circ}$ - El imperativo ético que ordena llevar a cabo todos los esfuerzos conducentes a fortalecer los vínculos que unen a la nación chilena, dejando atrás odiosidades hoy carentes de sentido, y fomentando todas las iniciativas que consoliden la reunificación de los chilenos;

$3^{\circ}$ - La necesidad de una férrea unidad nacional que respalde el avance hacia la nueva institucionalidad que debe regir los destinos de Chile.

La Junta de Gobierno ha acordado dictar el siguiente Decreto ley:

Artículo $1^{\circ}$ - Concédese amnistía a todas las personas que, en calidad de autores, cómplices o encubridores hayan incurrido en hechos delictuosos, durante la vigencia de la situación de Estado de Sitio, comprendida entre el 11 de Septiembre de 1973 y el 10 de Marzo de 1978, siempre que no se encuentren actualmente sometidas a proceso o condenadas.

Artículo $2^{\circ}$ - Amnistíase, asimismo, a las personas que a la fecha de vigencia del presente decreto ley se encuentren condenadas por tribunales militares, con posterioridad al 11 de septiembre de 1973.

Artículo $3^{\circ}$ - No quedarán comprendidas en la amnistía a que se refiere el artículo $1^{\circ}$, las personas respecto de las cuales hubiere acción penal vigente en su contra por los delitos de parricidio, infanticidio, robo con fuerza en las cosas, o con violencia o intimidación en las personas, elaboración o tráfico de estupefacientes, sustracción de menores de edad, corrupción de menores, incendios y otros estragos; violación, estupro, incesto, manejo en estado de ebriedad, malversación de caudales o efectos públicos, fraudes y exacciones ilegales, estafas y otros engaños, abusos deshonestos, delitos contemplados en el decreto ley número 280 , de 1974, y sus posteriores modificaciones; cohecho, fraude y contrabando aduanero y delitos previstos en el Código Tributario.

Artículo $4^{\circ}$ - Tampoco serán favorecidas con la aplicación del artículo $1^{\circ}$, las personas que aparecieren responsables, sea en calidad de autores, cómplices o encubridores, de los hechos que se investigan en proceso rol $N^{\circ} 192-78$ del Juzgado Militar de Santiago, Fiscalía Ad Hoc.

Artículo $5^{\circ}$ - Las personas favorecidas por el presente decreto ley, que se encuentren fuera del territorio de la República, deberán someterse a lo dispuesto en el artículo $3^{\circ}$ del decreto ley $\mathrm{N}^{\circ} 81$, de 1973, para reingresar al país.

\section{c) Hechos posteriores al 21 de agosto de 1990}

\section{i) Procedimiento judicial a nivel interno}

82.11. El 4 de noviembre de 1992 la señora Gómez Olivares, a través de su representante, presentó querella criminal ante el Primer Juzgado del Crimen de Rancagua y solicitó la reapertura la causa No. $40.184^{45}$. En virtud de lo anterior, el Juzgado dejó sin efecto el sobreseimiento temporal ${ }^{46}$ (supra párr. 82.9), y tomó los testimonios de los señores Manuel Segundo Castro Osorio ${ }^{47}$ y Raúl Hernán Neveu Cortesi $^{48}$, presuntos responsables de la muerte del señor Almonacid.

$45 \quad$ Cfr. querella criminal presentada por Elvira del Rosario Gómez Olivares el 4 de noviembre de 1992, (expediente de anexos a los alegatos finales escritos del Estado, Anexo 1, folios 1694 a 1696).

$46 \quad$ Cfr. resolución del Primer Juzgado del Crimen de Rancagua de 5 de noviembre de 1992, (expediente de anexos a los alegatos finales escritos del Estado, Anexo 1, folio 1697).

$47 \quad$ Cfr. declaración de Castro Osorio de 18 de noviembre de 1992 ante el Primer Juzgado del Crimen de Rancagua, (expediente de anexos a los alegatos finales escritos del Estado, Anexo 1, folios 1698 a 1700). 
82.12. Por resoluciones de 3 de febrero ${ }^{49}$ y 3 de junio de $1993^{50}$, y 5 de abril de $1994^{51}$, el Juez Primero del Crimen de Rancagua se declaró incompetente para conocer la causa y ordenó la remisión de la misma a la Fiscalía Militar y de Carabineros de San Fernando. Frente a tales resoluciones la señora Gómez Olivares, a través de su representante, presentó recursos de reposición y apelación los días 9 de febrero ${ }^{52}$ y 5 de junio de $1993^{53}$, y 8 de abril de $1994^{54}$, respectivamente. El Juzgado Primero del Crimen declaró "no ha lugar" los recursos de reposición, mediante resoluciones de 25 de febrero ${ }^{55}$ y 7 de junio de $1993^{56}$, y 9 de abril de $1994^{57}$, respectivamente, y remitió el expediente a la Corte de Apelaciones, a efectos de que ésta resolviera sobre los recursos de apelación. La Corte de Apelaciones revocó las resoluciones de incompetencia del Juez Primero, mediante resoluciones de fechas 5 de abril $^{58}$ y 9 de noviembre de $1993^{59}$, y 11 de octubre de $1994^{60}$, respectivamente, puesto que consideró que no se habían agotado las investigaciones y no existía la certeza suficiente para determinar la calidad de civil o militar de las personas que participaron en los hechos. En consecuencia, se mantuvieron abiertas las investigaciones.

$48 \quad$ Cfr. declaración de Neveu Cortesi de 12 de enero de 1993 ante el Primer Juzgado del Crimen de Rancagua, (expediente de anexos a los alegatos finales escritos del Estado, Anexo 1, folio 1707).

49 Cfr. resolución del Primer Juzgado del Crimen de Rancagua de 3 de febrero de 1993, (expediente de anexos a los alegatos finales escritos del Estado, Anexo 1, folio 1711).

50 Cfr. resolución del Primer Juzgado del Crimen de Rancagua de 3 de junio de 1993, (expediente de anexos a los alegatos finales escritos del Estado, Anexo 1, folio 1740).

51 Cfr. resolución del Primer Juzgado del Crimen de Rancagua de 5 de abril de 1994, (expediente de anexos a los alegatos finales escritos del Estado, Anexo 1, folio 1774).

52 Cfr. recursos de reposición y apelación presentados por el representante de la señora Gómez Olivares el 9 de febrero de 1993, (expediente de anexos a los alegatos finales escritos del Estado, Anexo 1, folios 1718 y 1719).

53 Cfr. recursos de reposición y apelación presentados por el representante de la señora Gómez Olivares el 5 de junio de 1993, (expediente de anexos a los alegatos finales escritos del Estado, Anexo 1, folios 1741 y 1742).

$54 \quad$ Cfr. recursos de reposición y apelación presentados por el representante de la señora Gómez Olivares el 8 de abril de 1994, (expediente de anexos a los alegatos finales escritos del Estado, Anexo 1, folios 1777 y 1778).

55 Cfr. resolución del Primer Juzgado del Crimen de Rancagua de 25 de febrero de 1993, (expediente de anexos a los alegatos finales escritos del Estado, Anexo 1, folio 1721).

56 Cfr. resolución del Primer Juzgado del Crimen de Rancagua de 7 de junio de 1993, (expediente de anexos a los alegatos finales escritos del Estado, Anexo 1, folio 1742).

57 Cfr. resolución del Primer Juzgado del Crimen de Rancagua de 9 de abril de 1994, (expediente de anexos a los alegatos finales escritos del Estado, Anexo 1, folio 1779).

58 Cfr. resolución de la Corte de Apelaciones de Rancagua de 5 de abril de 1993, (expediente de anexos a los alegatos finales escritos del Estado, Anexo 1, folio 1730).

59 Cfr. resolución de la Corte de Apelaciones de 9 de noviembre de 1993, (expediente de anexos a los alegatos finales escritos del Estado, Anexo 1, folio 1747).

60 Cfr. resolución de la Corte de Apelaciones de 11 de octubre de 1994, (expediente de anexos a los alegatos finales escritos del Estado, Anexo 1, folio 1788). 
82.13. El 23 de diciembre de 1994 el Primer Juzgado del Crimen declaró cerrado el sumario $^{61}$, frente a lo cual el 28 de diciembre del mismo año, la señora Gómez Olivares, a través de su representante, solicitó al Juez que se deje "sin efecto" esta resolución ${ }^{62}$. El 2 de enero de 1995 el Juez dejó sin efecto su anterior resolución ${ }^{63}$. No obstante, el 8 de febrero de 1995 el mismo Juez declaró nuevamente cerrado el sumario ${ }^{64}$. Seguidamente, el 15 de febrero de 1995 el Juez sobreseyó definitivamente la causa, en aplicación del Decreto Ley No. 2.19165 (supra párr. 82.10). El 3 de noviembre de 1995 la Corte de Apelaciones decidió revocar tal sobreseimiento y "reponer" la causa a la etapa del sumario, "por no encontrarse agotada la investigación"66. El 5 de junio de 1996 el Primer Juzgado del Crimen nuevamente declaró cerrado el sumario ${ }^{67}$. La Corte de Apelaciones decidió revocar esta resolución y, además, ordenó al Juez "perseguir la responsabilidad criminal" del presunto responsable Neveu Cortesi ${ }^{68}$.

82.14. El 31 de agosto de 1996 el Primer Juzgado del Crimen de Rancagua dictó resolución mediante la cual "somet[ió] a proceso a [Manuel Segundo Castro Osorio], como cómplice[,] y a [Raúl Hernán Neveu Cortesi], como autor del delito de homicidio de Luis Alfredo Almonacid Arellano". Asimismo, el Juzgado dictó órdenes de aprehensión en contra de Castro Osorio y ofició a la Prefectura de Carabineros de Curicó a fin de que se ponga a su disposición a Neveu Cortesi ${ }^{69}$.

82.15. El 3 de octubre de 1996 el Juzgado del Crimen de Rancagua decidió dictar la excarcelación bajo fianza del señor Castro Osorio ${ }^{70}$, decisión que fue confirmada por la Corte de Apelaciones el 4 de octubre de $1996^{71}$. Inmediatamente después, el 5 de octubre de 1996, Castro Osorio presentó un recurso de apelación en contra de la

61 Cfr. resolución del Primer Juzgado del Crimen de Rancagua de 23 de diciembre de 1994, (expediente de anexos a los alegatos finales escritos del Estado, Anexo 1, folio 1796).

62 Cfr. escrito de 28 de diciembre de 1994 del representante de la señora Gómez Olivares, (expediente de anexos a los alegatos finales escritos del Estado, Anexo 1, folios 1797 y 1798).

63 Cfr. resolución del Primer Juzgado del Crimen de Rancagua de 2 de enero de 1995, (expediente de anexos a los alegatos finales escritos del Estado, Anexo 1, folio 1798).

64 Cfr. resolución del Primer Juzgado del Crimen de Rancagua de 8 de febrero de 1995, (expediente de anexos a los alegatos finales escritos del Estado, Anexo 1, folio 1802).

65 Cfr. resolución del Primer Juzgado del Crimen de Rancagua de 15 de febrero de 1995 (expediente de anexos a los alegatos finales escritos del Estado, Anexo 1, folio 1803).

66 Cfr. resolución de la Corte de Apelaciones de Rancagua de 3 de noviembre de 1995, (expediente de anexos a los alegatos finales escritos del Estado, Anexo 1, folio 1817).

67 Cfr. resolución del Primer Juzgado del Crimen de Rancagua de 5 de junio de 1996, (expediente de anexos a los alegatos finales escritos del Estado, Anexo 1, folio 1854).

68 Cfr. resolución de la Corte de Apelaciones de Rancagua de 28 de agosto de 1996, (expediente de anexos a los alegatos finales escritos del Estado, Anexo 1, folios 1873 y 1874).

$69 \quad$ Cfr. resolución del Primer Juzgado del Crimen de Rancagua de 31 de agosto de 1996, (expediente de anexos a los alegatos finales escritos del Estado, Anexo 1, folios 1877 y 1878).

70 Cfr. resolución del Primer Juzgado del Crimen de Rancagua de 3 de octubre de 1996, (expediente de anexos a los alegatos finales escritos del Estado, Anexo 1, folio 1902).

71 Cfr. resolución de la Corte de Apelaciones de Rancagua de 4 de octubre de 1996, (expediente de anexos a los alegatos finales escritos del Estado, Anexo 1, folio 1907). 
decisión del Primer Juzgado del Crimen que lo sometió a proceso ${ }^{72}$ (supra párr. 82.14). La Corte de Apelaciones decidió revocar la resolución apelada y declarar al señor Castro Osorio como no procesado ${ }^{73}$.

82.16. El 27 de septiembre de 1996 el Segundo Juzgado Militar de Santiago se dirigió al Primer Juzgado del Crimen de Rancagua y le solicitó que se inhibiera de seguir conociendo la causa, en vista de que los procesados Castro Osorio y Neveu Cortesi "a la fecha de los hechos se encontraban en servicio activo, estando sujetos al fuero militar". Asimismo, el Juzgado Militar señaló que al momento de los hechos "estaba en vigencia el [Decreto Ley] No. 5, de 12 de [s]eptiembre de 1973, que declaró [...] el estado de sitio[,] decretado por conmoción interna[, y que] en las circunstancias que vivía el país debía entenderse estado o tiempo de guerra" ${ }^{74}$. El 7 de octubre de 1996 el Primer Juzgado del Crimen negó la solicitud de inhibición presentada por el Segundo Juzgado Militar, porque "no e[ra] posible inferir que los inculpados de autos, se hayan encontrado en acto de servicio al momento de ocurri[r] los hechos"75. De esta forma quedó trabado el incidente de competencia ante la Corte Suprema.

82.17. El 5 de diciembre de 1996 la Corte Suprema resolvió el incidente de competencia (supra párr. 82.16) declarando que "es competente para seguir conociendo el asunto el Segundo J uzgado Militar de Santiago, al cual se deberá remitir" el expediente ${ }^{76}$.

82.18. El 16 de diciembre de 1996 el Segundo Juzgado Militar instruyó sumario a través de la Segunda Fiscalía de Ejército y Carabineros de Santiago ${ }^{77}$. El 13 de enero de 1997 el referido Juzgado Militar acumuló la causa No. 40.184, seguida hasta ese entonces en el Primer Juzgado del Crimen de Rancagua, a la causa 876-96, seguida ante si $^{78}$.

82.19. El 14 de enero de 1997 la Segunda Fiscalía de Ejército y Carabineros de Santiago solicitó al Segundo J uzgado Militar que "dicte sobreseimiento total y definitivo [por encontrarse] extinguida la responsabilidad penal" de Castro Osorio y Neveu Cortesi, en virtud del Decreto Ley No. 2.19199.

72 Cfr. recurso de apelación interpuesto por el representante de Castro Osorio el 5 de octubre de 1996, (expediente de anexos a los alegatos finales escritos del Estado, Anexo 1, folios 1917 y 1918).

73 Cfr. resolución de la Corte de Apelaciones de Rancagua de 30 de octubre de 1996, (expediente de anexos a los alegatos finales escritos del Estado, Anexo 1, folio 2044).

$74 \quad$ Cfr. incidente de competencia presentado por el Segundo Juzgado Militar de Santiago contra el Primer Juzgado del Crimen de Rancagua el 27 de septiembre de 1996, (expediente de anexos a los alegatos finales escritos del Estado, Anexo 1, folios 1886 y 1887).

75 Cfr. resolución del Primer Juzgado del Crimen de Rancagua de 7 de octubre de 1996, (expediente de anexos a los alegatos finales escritos del Estado, Anexo 1, folio 1916).

76 Cfr. resolución de la Corte Suprema de Justicia de 5 de diciembre de 1996, (expediente de anexos a los alegatos finales escritos del Estado, Anexo 1, folio 1931).

77 Cfr. resolución del Segundo Juzgado Militar de Santiago de 16 de diciembre de 1996, (expediente de anexos a los alegatos finales escritos del Estado, Anexo 1, folio 1933).

78 Cfr. resolución del Segundo Juzgado Militar de Santiago de 13 de enero de 1997, (expediente de anexos a los alegatos finales escritos del Estado, Anexo 1, folio 1970).

79 Cfr. comunicación de 14 de enero de 1997 de la Segunda Fiscalía Militar de Santiago, (expediente de anexos a los alegatos finales escritos del Estado, Anexo 1, folios 1934 y 1935). 
82.20. El 28 de enero de 1997 el Segundo Juzgado Militar de Santiago, sin realizar ninguna diligencia probatoria ni establecer que hubiese quedado agotada la investigación, dictó sobreseimiento total y definitivo, en aplicación del Decreto Ley No. 2.191. Entre los considerandos de esta resolución el Juzgado Militar señaló que:

el derecho se inspira en dos valores que le son propios, a saber, la justicia y la seguridad jurídica.

En la medida en que las normas jurídicas están basadas en estos valores el derecho podrá lograr un fin último que es la paz social.

La amnistía es una institución que fundada en la seguridad jurídica, en cierta medida prescinde de la justicia, con el objeto de obtener la paz social, fin último y esencial del derecho que[ da] razón a su existencia.

$[\ldots]$

[U]n Estado de Derecho como el de Chile se expresa entre otras conductas básicas en el imperio de la ley, por lo que el mandato de la ley de amnistía no puede quebrantarse sin alterar el orden constitucional y la legalidad inscrito en él.

[E]l efecto de la amnistía se retrotrae al momento mismo en que el delito fue cometido, por lo [que] dictada una ley de amnistía y establecido que el hecho [quedó] comprendido dentro del período por ella cubiert[o] deben sobreseerse definitivamente los procesos pendientes".

$[\ldots]$

[C]on la amnistía el delito deja de serlo, por lo que resulta absolutamente inútil [agotar] la investigación en el caso de un hecho respecto del cual está acreditado que acaeció durante el período cubierto por la amnistía.

En todo caso, cabe señalar que en la especie la investigación de autos está completamente agotada $^{80}$.

82.21. El 26 de febrero de 1997 la señora Gómez Olivares, a través de su representante, presentó un recurso de apelación en contra del sobreseimiento definitivo dictado en la causa. Fundamentó el recurso señalando, inter alia, que el sobreseimiento dictado no "asegura precisamente la paz social ni la estabilidad del estado de Derecho" y la "copiosa legislación internacional suscrita por Chile [...] hace improcedente la aplicación de la amnistía" ${ }^{81}$. El expediente se remitió a la Corte Marcial, la cual el 25 de marzo de 1998 confirmó la resolución del Segundo Juzgado Militar (supra párr. 82.20). Entre los considerandos de su sentencia la Corte Marcial reprodujo lo señalado por la jurisprudencia de la Corte Suprema de Justicia en el sentido de que

\begin{abstract}
la amnistía [es] una causal objetiva de extinción de responsabilidad criminal [y] sus efectos se producen de pleno derecho a partir del momento establecido por la ley, sin que puedan ser rehusados por sus beneficiarios [...], pues se trata de leyes de derecho público, que miran al interés general de la sociedad. Lo expresado significa, que una vez verificada la procedencia de la ley de amnistía deben los jueces proceder a declararla [...], sin que en consecuencia tenga obligatoria aplicación lo dispuesto en el artículo 413 [del Código de Procedimiento Penal], que exige para decretar el sobreseimiento definitivo que esté agotada la investigación con que se haya tratado de comprobar el cuerpo del delito y determinar la persona del delincuente ${ }^{82}$.
\end{abstract}

\title{
La Corte Marcial continuó indicando que
}

80 Cfr. sobreseimiento No. 28 dictado por el Segundo Juzgado Militar de Santiago el 28 de enero de 1997, (expediente de anexos a los alegatos finales escritos del Estado, Anexo 1, folios 1936 a 1938 y 1974 a 1976).

81 Cfr. recurso de apelación presentado por el representante de la señora Gómez Olivares el 26 de febrero de 1997, (expediente de anexos a los alegatos finales escritos del Estado, Anexo 1, folio 1949).

82 Cfr. sentencia de la Corte Marcial de 25 de marzo de 1998, considerando 5, (expediente de anexos a la demanda, Anexo 3, folio 41). 
se ha establecido fehacientemente la existencia de ilícito penal (homicidio) [del señor Almonacid Arellano], y su concurrencia en el período de tiempo que cubre la amnistía, como asimismo se ha dictado auto de procesamiento en contra de las personas que aparecen como responsables. Que, siendo así, el decreto ley sobre amnistía tiene plena eficacia, razón por la cual corresponde a los jueces darle aplicación sobreseyendo definitivamente el proceso, toda vez que las responsabilidades penales se han extinguido, perdiendo el juicio penal su finalidad ${ }^{83}$

En lo referente a la aplicación de los convenios internacionales sobre derechos humanos, la Corte Marcial consideró que

no puede sostenerse en concepto de esta Corte que dichos instrumentos internacionales son idóneos para restar eficacia al [Decreto Ley No. 2.191 ... E]n efecto, el Pacto de San José de Costa Rica fue ratificado el 21 de agosto de 1990[,] en tato que el Pacto Internacional de Derechos Civiles y Políticos se incorporó al derecho chileno con fecha 29 de abril de 1989, razón por la cual, no puede retrotraerse su aplicación, afectando al principio de la irretroactividad de la ley penal, puesto que ello equivaldría a sostener que responsabilidades penales definitivamente extinguidas en virtud de la amnistía han tenido la virtud de renacer después. Lo anterior contradice la esencia de la amnistía que es siempre ley penal más benigna para quienes resulten favorecidos por ella ${ }^{84}$.

Una Ministra de la Corte Marcial no estuvo de acuerdo con lo resuelto por la mayoría, puesto que consideró que el "homicidio" del señor Almonacid Arellano se perpetró en una "época en que imperaba en el país un estado de guerra interna", y que tal acto, "atendidas las circunstancias y modalidad de su comisión, [...] es una de las acciones prohibidas por el artículo 3 [común] de los Convenios de Ginebra". Asimismo, la Ministra indicó que el artículo 52 de los Convenios de Ginebra "hace claramente imprescriptible e inadmistiable los crímenes de guerra" ${ }^{85}$.

82.22. El 9 de abril de 1998 la señora Gómez Olivares, a través de su representante, interpuso recurso de casación en contra de la sentencia de la Corte Marcial (supra párr. 82.21), en el cual presentó, inter alia, los siguientes alegatos:

de acuerdo al código procesal penal [...] se prohíbe a los jueces decretar sobreseimientos definitivos antes de estar agotada una investigación [...]. En el caso de autos, la investigación distaba de estar agotada, faltando importantes diligencias, entre las cuales contaban la determinación de los integrantes de la patrulla de Carabineros y eventualmente la aparición de nuevos antecedentes que permitieron identificar otros responsables del homicidio [del señor Almonacid Arellano];

[...]

el decreto ley de amnistía puede seguir teniendo eficacia, pero en todo aquello que no haya sido regulado o prohibido por la norma internacional. [Pero] tratándose de homicidios cometidos por agentes estatales, se configura un ilícito internacional, respecto del cual 'la soberanía nacional' [...] queda necesariamente restringida para otorgarles un indiscriminado perdón o amnistía;

[...]

el derecho a la verdad y a la justicia que asisten a los familiares de las víctimas es un derecho originario y de mayor jerarquía, que aquel que se reclama en favor de los delincuentes cuando se persigue su responsabilidad criminal en los hechos y que deviene en un derecho derivado; y $[\ldots]$

83 Cfr. sentencia de la Corte Marcial de 25 de marzo de 1998, considerando 6 (expediente de anexos a la demanda, Anexo 3, folio 42).

$84 \quad$ Cfr. sentencia de la Corte Marcial de 25 de marzo de 1998, considerando 9 (expediente de anexos a la demanda, Anexo 3, folios 43 y 44).

85 Cfr. voto disidente de la Ministra Morales a la Sentencia de la Corte Marcial de 25 de marzo de 1998 (expediente de anexos a la demanda, Anexo 3, folios 44 y 45). 
de las Convenciones de Ginebra y la ley de amnistía, [...] se infiere que la amnistía puede tener eficacia sobre todas aquellas materias que no sean las 'graves infracciones señaladas en los Convenios de Ginebra'86.

82.23. La Corte Suprema resolvió este recurso el 16 de abril de 1998, declarándolo "no ha lugar por extemporáneo"87. El 11 de noviembre de 1998 se ordenó el archivo del expediente ${ }^{88}$.

\section{ii) Medidas adoptadas por el Estado respecto al Decreto Ley No. 2.191}

82.24. Hasta la fecha de la presente Sentencia se han presentado 6 proyectos de ley tendientes a modificar el Decreto Ley No. 2.191. Dos de ellos ${ }^{89}$ pretendían que a través de una ley se interpretara el decreto ley señalado, estableciendo que éste no es aplicable a los crímenes de lesa humanidad, por su carácter de inadmistiables e imprescriptibles. Un tercero ${ }^{90}$ pretendía ampliar el período cubierto por el Decreto Ley hasta el 11 de marzo de 1990. Un cuarto proyecto ${ }^{91}$ buscaba impedir que se inicie proceso alguno destinado a hacer valer la responsabilidad de quienes aparezcan en ellos como autores, cómplices o encubridores, "entendiéndose extinguida toda acción penal o civil que de ellos haya emanado" y proponía el sobreseimiento definitivo "sin más trámite" de los juicios que se encontraran pendientes. Un quinto proyecto ${ }^{92}$ tenía el propósito de reglar la aplicación del Decreto Ley y establecer que en caso de personas detenidas-desaparecidas el juez continuaría las investigaciones "con el sólo propósito de esclarecer el destino de la víctima o de sus restos". Ninguno de estos cinco proyectos fue aprobado. Un sexto proyecto ${ }^{93}$ fue recientemente presentado con la finalidad de declarar la nulidad de derecho público del Decreto Ley No. 2.191. La Corte desconoce el estado del trámite legislativo de este último proyecto.

82.25. En los últimos años el Poder Judicial chileno ha inaplicado el Decreto Ley No. 2.191 en varios $\operatorname{casos}^{94}$.

$86 \quad$ Cfr. recurso de casación presentado por el representante de la señora Gómez Olivares, (expediente de anexos a los alegatos finales escritos del Estado, Anexo 1, folios 2000 a 2016).

87 Cfr. resolución de la Corte Suprema de 16 de abril de 1998, (expediente de anexos a los alegatos finales escritos del Estado, Anexo 1, folio 2019).

88 Cfr. orden de archivo de 11 de noviembre de 1998, (expediente de anexos a los alegatos finales escritos del Estado, Anexo 1, folio 2039).

89 Cfr. boletín No. 654-07, presentado el 7 de abril 1992 por los senadores Rolando Calderón Aránguiz, Jaime Gazmuri Mujica, Ricardo Núñez Muñoz y Hernán Vodanovic Schnake (expediente de anexos a los alegatos finales escritos del Estado, Anexo 10, folios 4269 a 4274); Boletín No. 1718-07, presentado el 11 de octubre de 1995 por los senadores Ruiz de Giorgio y Mariano Ruiz Esquide (expediente de anexos a los alegatos finales escritos del Estado, Anexo 11, folios 4276 a 4285).

$90 \quad$ Cfr. boletín No. 1.622-07, presentado el 6 de junio 1995 por el senador Sebastián Piñera Echenique (expediente de anexos a los alegatos finales escritos del Estado, Anexo 12, folios 4365 a 4371).

91 Cfr. boletín No. 1632-07, presentado el día 14 de junio 1995 por el senador Francisco Javier Errazuriz (expediente de anexos a los alegatos finales escritos del Estado, Anexo 13, folios 4373 a 4377 ).

92 Cfr. boletín No. 1657-07, presentado el 19 de julio de 1995 por los senadores Diez, Larraín, Otero y Piñera (expediente de anexos a los alegatos finales escritos del Estado, Anexo 14, folios 4379 a 4389 ).

$93 \quad$ Cfr. boletín No. 4162-07, presentado el 21 de abril de 2006 por los senadores Girardi, Letelier, Navarro y Ruiz-Esquide (Anexo 9 alegatos finales escritos del Estado, folios 4249 a 4267).

$94 \quad$ Cfr. Corte de Apelaciones de Santiago, Recurso de Apelación Rol No. 38683-94 de 30 de septiembre de 1994 (expediente de documentos presentados en la Audiencia Pública, folios 483 a 495); Corte Suprema, 
d) Medidas de reparación adoptadas frente a las graves violaciones a los derechos humanos cometidas durante el Gobierno de facto

82.26. El 25 de abril de 1990, inmediatamente después del fin de la Dictadura Militar, el Presidente Patricio Aylwin Azocar, considerando, inter alia, "[q]ue la conciencia moral de la Nación requiere el esclarecimiento de la verdad sobre las graves violaciones a los derechos humanos cometidas en el país entre el 11 de septiembre de 1973 y el 11 de marzo de 1990"95 dictó el Decreto Supremo No. 355 que creó la Comisión Nacional de Verdad y Reconciliación (en adelante "la Comisión de la Verdad"). La tarea de este organismo era:

a) Establecer un cuadro lo más completo posible sobre los graves hechos referidos, sus antecedentes y circunstancias;

b) Reunir antecedentes que permitan individualizar a sus víctimas y establecer su suerte o paradero;

c) Recomendar medidas de reparación y reivindicación que crea de justicia; y

Recurso de Casación Rol No. 3831-97 de 8 de junio de 1998 (expediente de documentos presentados en la Audiencia Pública, folios 186 a 196); Corte Suprema, Recurso de Casación Rol No. 469-98 de 9 de septiembre de 1998 (expediente de documentos presentados en la Audiencia Pública, folios 364 a 380); Corte Suprema, Recurso de Casación Rol No. 2097-1998 de 29 de diciembre de 1998 (expediente de documentos presentados en la Audiencia Pública, folios 299 a 305); Corte Suprema, Recurso de Casación Rol No. 247-98 de 7 de enero de 1999 (expediente de documentos presentados en la Audiencia Pública, folios 197 a 206); Corte Suprema, Recurso de Casación Rol No. 1359-2001 de 26 de agosto de 2002 (expediente de documentos presentados en la Audiencia Pública, folios 220 a 234); Corte Suprema, Recurso de Casación Rol No. 4135-2001 de 29 de noviembre de 2002 (expediente de documentos presentados en la Audiencia Pública, folios 207 a 219); Corte Suprema, Recurso de Casación Rol No. 4054-2001 de 31 de enero de 2003 (expediente de documentos presentados en la Audiencia Pública, folios 272 a 283); Corte Suprema, Recurso de Casación Rol No. 4053-2001 de 31 de enero de 2003 (expediente de documentos presentados en la Audiencia Pública, folios 253 a 271); Corte Suprema, Recurso de Casación Rol No. $4209-01$ de 3 de marzo de 2003 (expediente de documentos presentados en la Audiencia Pública, folios 284 a 298); Corte Suprema, Recurso de Casación Rol No. 2231-01 de 28 de agosto de 2003 (expediente de documentos presentados en la Audiencia Pública, folios 235 a 252); Corte Suprema, Recurso de Casación Rol No. 1134-2002 de 4 de noviembre de 2003 (expediente de documentos presentados en la Audiencia Pública, folios 306 a 316); Corte Suprema, Recurso de Casación Rol No. 2505-2002 de 11 de noviembre de 2003 (expediente de documentos presentados en la Audiencia Pública, folios 317 a 324); Corte de Apelaciones de Santiago, Recurso de Apelación Rol No. 11821-2003, de 5 de enero de 2004 (expediente de documentos presentados en la Audiencia Pública, folios 443 a 475); Corte Suprema, Recurso de Casación, Rol No. 457-2005, de 9 de febrero de 2005 (expediente de documentos presentados en la Audiencia Pública, folios 424 a 437); Corte Suprema, Recurso de Casación Rol No. 4622-2002, de 29 de marzo de 2005 (expediente de documentos presentados en la Audiencia Pública, folios 325 a 339); Corte de Apelaciones de Santiago, Recurso de Revisión Rol No. 15765-2004, de 6 de julio de 2005 (expediente de documentos presentados en la Audiencia Pública, folios 438 a 442); Corte Suprema, Rol No. 3925 -2005, de 5 de septiembre de 2005 (expediente de documentos presentados en la Audiencia Pública, folios 390 a 423); Corte de Apelaciones de Santiago, Recurso de Apelación Rol No. 37483-2004, resolución 8472, dictada por la Secretaria Criminal, de 18 de enero de 2006 (expediente de anexos a los alegatos finales escritos del Estado, Anexo 4, Tomo II, folios 4170 a 4179); Corte de Apelaciones de Santiago, Recurso de Apelación Rol No. 24471-2005, resolución 43710, dictada por la Secretaría Criminal, 20 de abril de 2006 (expediente de fondo, Tomo IV, folios 1089 a 1093); Corte Suprema, Recurso de Queja Rol No. 396-2006, Resolución 9334, dictada por la Secretaría Única, de 8 de mayo de 2006 (expediente de fondo, Tomo IV, folios 1094 y 1095); Corte Suprema, Recurso de Casación Rol No. 3215-2005, Resolución 11745, dictada por la Secretaría Única, de 30 de mayo de 2006 (expediente de fondo, Tomo IV, folios 1157 a 1159); Corte de Apelaciones de Santiago, Rol No. 14567-2004, Resolución 64656, dictada por la Secretaría Criminal, de 2 de junio de 2006 (expediente de fondo, Tomo IV, folios 1160 y 1161); Corte de Apelaciones de Santiago, Rol No. 14058-2004, Resolución 74986, dictada por la Secretaria Criminal, de 27 de junio de 2006 (expediente de fondo, Tomo IV, folios 1263 a 1270); Corte de Apelaciones de Santiago, Rol No. 32365-2005, Resolución 76786, dictada por la Secretaria Criminal, de 29 de junio de 2006 (expediente de fondo, Tomo IV, folios 1260 a 1262).

95 Cfr. considerando primero del Decreto Supremo No. 355 de 25 de abril de 1990, en Informe de la Comisión Nacional de Verdad y Reconciliación, Tomo I, págs. XI a XIV (expediente de anexos a los alegatos finales escritos del Estado, Anexo 2, folios 2077 a 2079). 
d) Recomendar las medidas legales y administrativas que a su juicio deben adoptarse para impedir o prevenir la comisión de los hechos a que este artículo se refiere.

\title{
El Decreto Supremo No. 355 entendió por graves violaciones
}

\begin{abstract}
las situaciones de detenidos desaparecidos, ejecutados y torturados con resultado de muerte, en que aparezca comprometida la responsabilidad moral del Estado por actos de sus agentes o de personas a su servicio, como asimismo los secuestros y los atentados contra la vida de personas cometidos por particulares bajo pretextos políticos ${ }^{96}$.
\end{abstract}

82.27. Luego de concluida su labor la Comisión de la Verdad emitió su informe, acordado por unanimidad de sus miembros, e hizo entrega del mismo al Presidente Aylwin el 8 de febrero de $1991^{97}$. A su vez, el Presidente Aylwin dio a conocer el informe a la sociedad el 4 de marzo de $1991^{98}$. En esa ocasión el Presidente pidió perdón a los familiares de las víctimas en los siguientes términos:

Cuando fueron agentes del Estado los que ocasionaron tanto sufrimiento, y los órganos competentes del Estado no pudieron o no supieron evitarlo o sancionarlo, y tampoco hubo la necesaria reacción social para impedirlo, son el Estado y la sociedad entera los responsables, bien sea por acción o por omisión. Es la sociedad chilena la que está en deuda con las víctimas de las violaciones a los derechos humanos.

$[\ldots]$

Por eso es que yo me atrevo, en mi calidad de Presidente de la República, a asumir la representación de la Nación entera para, en su nombre, pedir perdón a los familiares de la[s] víctimas ${ }^{99}$.

82.28. En el informe de la Comisión de la Verdad se nombra individualmente a las víctimas, incluido el señor Almonacid Arellano ${ }^{100}$. Asimismo, la Comisión de la Verdad propuso recomendaciones de reivindicación y reparación simbólica ${ }^{101}$, de carácter legal y administrativo ${ }^{102}$ y relativas al bienestar social ${ }^{103}$.

96 Cfr. artículo primero del Decreto Supremo No. 355 de 25 de abril de 1990, en Informe de la Comisión Nacional de Verdad y Reconciliación, Tomo I, págs. XI a XIV (expediente de anexos a los alegatos finales escritos del Estado, Anexo 2, folios 2077 a 2079).

97 Cfr. mensaje a la Nación del Presidente Patricio Aylwin al dar a conocer el Informe de la Comisión Nacional de Verdad y Reconciliación, 4 de marzo de 1991, en Informe de la Comisión Nacional de Verdad y Reconciliación, Tomo II, págs. 887 a 894 (expediente de anexos a los alegatos finales escritos del Estado, Anexo 2, folios 2529 a 2533).

$98 \quad$ Cfr. mensaje a la Nación del Presidente Patricio Aylwin, supra nota 97.

$99 \quad$ Cfr. mensaje a la Nación del Presidente Patricio Aylwin, supra nota 97.

100 Cfr. Informe de la Comisión Nacional de la Verdad y Reconciliación, Tomo II, pág. 904 y Tomo III, pág. 18 (expediente de anexos a los alegatos finales escritos del Estado, Anexo 2, folios 2233 y 2572).

101 Cfr. Informe de la Comisión Nacional de la Verdad y Reconciliación, Tomo II, págs. 824 y 825 (expediente de anexos a los alegatos finales escritos del Estado, Anexo 2, folio 2498).

102 Cfr. Informe de la Comisión Nacional de la Verdad y Reconciliación, Tomo II, págs. 826 y 827 (expediente de anexos a los alegatos finales escritos del Estado, Anexo 2, folio 2499).

103 Cfr. Informe de la Comisión Nacional de la Verdad y Reconciliación, Tomo II, págs. 827 a 836 (expediente de anexos a los alegatos finales escritos del Estado, Anexo 2, folios 2499 a 2504). 
82.29. El 8 de febrero de 1992 se publicó en el Diario Oficial la Ley No. 19.123 que creó la Corporación Nacional de Reparación y Reconciliación ${ }^{104}$. El objeto de esta Corporación era "la coordinación, ejecución y promoción de las acciones necesarias para el cumplimiento de las recomendaciones contenidas en el Informe de la Comisión Nacional de Verdad y Reconciliación"105. A tal efecto, se estableció una pensión mensual en beneficio de los familiares de las víctimas de violaciones a los derechos humanos o de la violencia política ${ }^{106}$, se les otorgó el derecho a recibir gratuitamente ciertos beneficios médicos ${ }^{107}$ y beneficios educacionales ${ }^{108}$, y se eximió a los hijos de las víctimas de realizar el servicio militar obligatorio, si así lo solicitaren ${ }^{109}$.

82.30. El 11 de noviembre de 2003 se publicó en el Diario Oficial el Decreto Supremo No. 1.040 que creó la Comisión Nacional sobre Prisión Política y Tortura, para el esclarecimiento de la verdad acerca de quiénes fueron las personas que sufrieron privación de libertad y tortura por razones políticas en el período de la Dictadura militar ${ }^{110}$. Asimismo, la Comisión propuso en su informe final medidas de reparación individuales (recogidas en la Ley No. 19.992) colectivas y simbólicas.

82.31. El 29 de octubre de 2004 se promulgó la Ley No. 19.980 que modificó la Ley No. 19.123 (supra párr. 82.29), ampliando y estableciendo nuevos beneficios a favor de los familiares de las víctimas, entre los que destacan el incremento del 50 por ciento del monto de la pensión de reparación mensual; la concesión al Presidente de la República de la facultad para otorgar un máximo de 200 pensiones de gracia, y la ampliación de los beneficios en salud ${ }^{111}$.

82.32. Además de las citadas medidas de reparación el Estado adoptó las siguientes: i) el Programa de Apoyo a los Presos Políticos que al 11 de marzo de 1990 se encontraban privados de la libertad; ii) el Programa de Reparación y Atención Integral de Salud (PRAIS) a los afectados por las violaciones a los derechos humanos; iii) el Programa de Derechos Humanos del Ministerio del Interior; iv) mejoras tecnológicas al Servicio Médico Legal; v) la Oficina Nacional del Retorno; vi) el Programa para Exonerados Políticos; vii) la restitución o indemnización por bienes confiscados y adquiridos por el Estado; viii) la creación de la Mesa de Diálogo sobre Derechos

104 Cfr. Ley No. 19.123, publicada en el Diario Oficial el 8 de febrero de 1993, (expediente de anexos a los alegatos finales escritos del Estado, Anexo 3, folios 3383 a 3395).

105 Cfr. artículo 1 de la Ley No. 19.123, publicada en el Diario Oficial el 8 de febrero de 1993 (expediente de anexos a los alegatos finales escritos del Estado, Anexo 3, folio 3383).

106 Cfr. artículos 17 a 27 de la Ley No. 19.123, publicada en el Diario Oficial el 8 de febrero de 1993 (expediente de anexos a los alegatos finales escritos del Estado, Anexo 3, folios 3389 a 3392).

107 Cfr. artículo 28 de la Ley No. 19.123, publicada en el Diario Oficial el 8 de febrero de 1993 (expediente de anexos a los alegatos finales escritos del Estado, Anexo 3, folio 3393).

108 Cfr. artículos 29 a 31 de la Ley No. 19.123, publicada en el Diario Oficial el 8 de febrero de 1993 (expediente de anexos a los alegatos finales escritos del Estado, Anexo 3, folios 3393 a 3394 ).

109 Cfr. artículo 32 de la Ley No. 19.123, publicada en el Diario Oficial el 8 de febrero de 1993 (expediente de anexos a los alegatos finales escritos del Estado, Anexo 3, folio 3394).

110 Cfr. Informe de la Comisión Nacional sobre prisión política y tortura, (expediente de anexos a los alegatos finales escritos del Estado, Anexo 4, folio 3430).

111 Cfr. Ley No. 19.980 publicada en el Diario Oficial el 29 de octubre de 2004, (expediente de anexos a la contestación a la demanda, folios 376 a 379). 
Humanos, y ix) la iniciativa presidencial "No hay mañana sin ayer" del Presidente Ricardo Lagos ${ }^{112}$.

82.33. Finalmente, el Estado ha construido varios memoriales en homenaje de las víctimas de violaciones a los derechos humanos ${ }^{113}$.

e) Medidas de reparación otorgadas a la señora Gómez Olivares y a su familia

82.34. La señora Gómez Olivares percibió una bonificación en el año 1992, y ha recibido una pensión mensual y tiene derecho a seguirla recibiendo de forma vitalicia. También es beneficiaria y tiene derecho a continuar recibiendo beneficios en materia de salud. De igual manera, los hijos de la señora Gómez Olivares y del señor Almonacid Arellano han recibido reparaciones económicas y educacionales, incluida la educación superior. Asimismo, tienen también beneficios en salud. En total, la señora Gómez Olivares y sus hijos han recibido transferencias directas por una suma de aproximadamente US\$ 98.000,00 (noventa y ocho mil dólares de los Estados Unidos de América), y han recibido becas de estudio por una suma aproximada de US\$ 12.180,00 (doce mil ciento ochenta dólares de los Estados Unidos de América) ${ }^{114}$.

82.35. El Estado procedió a la nominación de una calle con el nombre Luis Almonacid y de una Villa Profesor Luis Almonacid, ambas en la ciudad de Rancagua, e incluyó el nombre del señor Almonacid Arellano en el Memorial del Cementerio General de Santiago ${ }^{115}$.

f) Respecto a los daños causados a la señora Gómez Olivares y a su familia, y respecto a las costas y gastos

82.36. Debido a la falta de sanción de los responsables de la muerte del señor Almonacid Arellano, la señora Gómez Olivares y sus hijos padecieron sufrimientos.

82.37. La señora Gómez Olivares actuó a través de representantes en el trámite del presente caso ante la justicia interna y ante los órganos del Sistema Interamericano de Protección de los Derechos Humanos, lo cual ha producido costas y gastos.

\section{VIII \\ I NCUMPLI MI ENTO DE LOS DEBERES GENERALES CONTENI DOS en los ARtí Culos 1.1 y 2 de La Convención Ameri CANa}

\footnotetext{
112 Cfr. declaración de Cristián Correa Montt testigo propuesto por el Estado (expediente de fondo, Tomo II, folios 421 a 440).

113 Cfr. documento titulado "Memoriales construidos con Aportes del Programa de Derechos Humanos del Ministerio del Interior", anexo 1 al declaración de Cristián Correa Montt (expediente de fondo, Tomo II, folios 441 a 450); libro "Políticas de Reparación. Chile 1990-2004" de Elizabeth Lira y Brian Loveman, anexo 2 a la declaración de Cristián Correa Montt (expediente de fondo, Tomo II, folios 451 a 463).

114 Cfr. declaración de la señora Elvira Gómez Olivares en la audiencia pública del 29 de marzo de 2006; declaración de Cristián Correa Montt (expediente de fondo, Tomo II, folio 439); constancias de la División Pago de Beneficios del Departamento de Operaciones del Instituto de Normalización Provisional, de febrero de 2006 (expediente de anexos a los alegatos finales escritos del Estado, Anexo 4, tomo II, folios 4392 a 4394).

115 Cfr. declaración de la señora Elvira Gómez Olivares (audiencia pública celebrada el 29 de marzo de 2006); listado de obras Rancagua http://www.ddhh.gov.cl/DDHH/obras/info_VIR/VIR_rancagua.html (expediente de anexos a la contestación de la demanda, folio 381).
} 


\section{( OBLIGACIÓN DE RESPETAR LOS DERECHOS Y \\ DEBER DE ADOPTAR DI SPOSI CI ONES DE DERECHO I NTERNO) \\ Y VIOLACIÓN DE LOS ARTÍ CULOS 8 Y 25 DE LA MI SMA \\ ( GARANTí AS J Udi CI ALES Y PROTECCI ÓN J Udi CI AL)}

83. Alegatos de la Comisión

a) la denegación de justicia en perjuicio de la familia del señor Almonacid Arellano deriva de la aplicación del Decreto Ley de auto amnistía, expedido por la dictadura militar como auto perdón, en beneficio de sus miembros. El Estado ha mantenido en vigor esa ley tras la ratificación de la Convención Americana; a su vez, los tribunales chilenos la han declarado constitucional y la continúan aplicando;

b) en el presente caso, es claro que la vigencia del Decreto Ley de auto amnistía afecta el derecho de las víctimas a que se investigue, se identifique y se juzgue a los individuos responsables de matar y herir a sus familiares. Esta ley en definitiva, afecta el derecho de las víctimas a la justicia;

c) la aplicación del Decreto Ley de auto amnistía tuvo el efecto de cercenar de forma definitiva el procedimiento judicial que tenía como objeto la investigación, persecución, captura, enjuiciamiento y condena de los responsables de la detención arbitraria y ejecución extrajudicial del señor Almonacid Arellano. En ese sentido, el Estado chileno ha violado los artículos 8, 25 y 1.1 de la Convención, en perjuicio de sus familiares;

d) otra consecuencia de la aplicación del Decreto Ley No. 2.191 y el subsiguiente archivo del proceso de investigación fue desconocer el derecho de los familiares del señor Almonacid Arellano a ser oídos por un tribunal competente, y

e) por otra parte, el hecho de que una investigación que involucra a miembros de carabineros haya sido confiada a la justicia militar plantea serías dudas acerca de su independencia e imparcialidad.

84. Alegatos del Representante

a) el crimen investigado en estos autos no es un delito común, sino un ilícito de carácter internacional que sobreponiéndose a las amnistías, prescripciones u otras instituciones extintivas de responsabilidad penal, da derecho a la acción procesal para su persecución, incluyendo el enjuiciamiento de los delincuentes y la sanción de los mismos;

b) el sobreseimiento definitivo por aplicación del Decreto Ley de Amnistía, manifiesta un absoluto desconocimiento de los alcances de la normativa que surge de la comunidad internacional, a la cual Chile ha concurrido soberanamente y la ha hecho suya, incorporándola al ordenamiento interno;

c) tratándose de homicidios cometidos por agentes estatales, se configura un ilícito internacional, respecto del cual la soberanía nacional, expresada en la suscripción de esos acuerdos internacionales, queda necesariamente restringida para otorgarles un indiscriminado perdón o amnistía; 
d) un Estado puede disponer libremente de su derecho interno, conforme a sus normas nacionales soberanas, pero no tiene competencia para modificar unilateralmente las situaciones cuya calificación jurídica viene dada por el derecho internacional. Si el derecho internacional califica como criminal un hecho y obliga al Estado a su sanción, no puede el Estado alterar dicha situación en virtud de su conveniencia interna;

e) la remisión de la causa a la justicia militar violó el artículo 8 de la Convención Americana, al entregarse el conocimiento de un homicidio a un tribunal que no era competente, independiente ni imparcial, y

f) en este efecto, no puede ser imparcial un sistema de juzgamiento como el militar, que pone a disposición sus medios para la defensa de una persona que eventualmente va a juzgar.

85. Alegatos del Estado

a) por principio, las leyes de amnistía o auto amnistía son contrarias a las normas de derecho internacional de los derechos humanos;

b) la jurisprudencia de los tribunales superiores de justicia en Chile, palpable desde el año 1998, ha encontrado más de un camino para evitar la aplicación del Decreto Ley de Amnistía y, con ello, evitar sus negativos efectos sobre el respeto de los derechos humanos, y

c) comparte la opinión de la Corte Interamericana que por principio es deseable que leyes de amnistía no existan, pero que, de existir, éstas no pueden ser un obstáculo para el respeto de los derechos humanos, tal como lo concluyó la Corte en el caso Barrios Altos.

\section{Consideraciones de la Corte}

86. El artículo 1.1 de la Convención establece que:

Los Estados partes en esta Convención se comprometen a respetar los derechos y libertades reconocidos en ella y a garantizar su libre y pleno ejercicio a toda persona que esté sujeta a su jurisdicción, sin discriminación alguna por motivos de raza, color, sexo, idioma, religión, opiniones políticas o de cualquier otra índole, origen nacional o social, posición económica, nacimiento o cualquier otra condición social.

87. Por su parte, el artículo 2 de la Convención determina que:

Si el ejercicio de los derechos y libertades mencionados en el artículo 1 no estuviere ya garantizado por disposiciones legislativas o de otro carácter, los Estados Partes se comprometen a adoptar, con arreglo a sus procedimientos constitucionales y a las disposiciones de esta Convención, las medidas legislativas o de otro carácter que fueren necesarias para hacer efectivos tales derechos y libertades.

88. El artículo 8.1 de la Convención establece que:

Toda persona tiene derecho a ser oída, con las debidas garantías y dentro de un plazo razonable, por un juez o tribunal competente, independiente e imparcial, establecido con anterioridad por la ley, en la sustentación de cualquier acusación penal formulada contra ella, o para la determinación de sus derechos y obligaciones de orden civil, laboral, fiscal o de cualquier otro carácter. 
89. A su vez, el artículo 25.1 de la Convención dispone que:

Toda persona tiene derecho a un recurso sencillo y rápido o a cualquier otro recurso
efectivo ante los jueces o tribunales competentes, que la ampare contra actos que violen
sus derechos fundamentales reconocidos por la Constitución, la ley o la presente
Convención, aún cuando tal violación sea cometida por personas que actúen en ejercicio
de sus funciones oficiales.

90. En el presente caso, la Corte ha sido llamada a pronunciarse respecto a si el Estado cumplió con los deberes generales establecidos en los citados artículos 1.1 y 2 de la Convención al mantener en vigencia el Decreto Ley No. 2.191 con posterioridad a la ratificación de la Convención por parte de Chile. Por otro lado, la Corte debe determinar si la aplicación del referido decreto ley constituye una violación de los derechos consagrados en los artículos 8.1 y 25 de la Convención, en relación con el artículo 1.1 de la misma, en perjuicio de las presuntas víctimas del presente caso. Para ello, el Tribunal estima oportuno dividir el análisis de la cuestión de la siguiente manera: a) primero, habría que calificar si el homicidio del señor Almonacid Arellano constituye o no un crimen de lesa humanidad, b) en segundo lugar y en caso que se establezca que tal homicidio constituye un crimen de lesa humanidad, la Corte considerará si dicho crimen puede o no ser amnistiado, c) en tercer lugar y en caso que se establezca que tal crimen no puede ser amnistiado, el Tribunal analizará si el Decreto Ley 2.191 amnistía o no este crimen y si el Estado violó o no la Convención al mantener vigente esa normativa, y d) finalmente, la Corte analizará si la aplicación de dicha normativa por parte de las autoridades judiciales en el presente caso conlleva una violación de los derechos consagrados en los artículos 8.1 y 25 de la Convención. Todo lo anterior será analizado en el apartado A) del presente capítulo.

91. Establecido lo anterior, la Corte pasará a examinar en el apartado B) de este capítulo lo alegado por la Comisión Interamericana y el representante de las presuntas víctimas respecto a que la jurisdicción militar no era la competente para conocer el presente caso, lo cual consideran como una violación del artículo 8.1 de la Convención Americana.

92. Es importante señalar que el Estado se ha limitado a contradecir la admisibilidad del caso - lo cual ya fue resuelto por este Tribunal en párrafos anteriores (supra párrs. 38 a 65) - y a señalar que los tribunales de justicia chilenos ya no aplican el Decreto Ley No. 2.191. La Corte desea recalcar que el Estado en ningún momento ha afirmado que el citado decreto ley no viola la Convención Americana. Incluso la Agente del Estado en la audiencia pública señaló:

Yo quiero que quede bien claro y vuelvo a repetir acá, el Estado de Chile no está haciendo una defensa del Decreto Ley de Amnistía. Por el contrario, nosotros no consideramos que el Decreto Ley de Amnistía tenga valor, ni ético ni jurídico ${ }^{116}$.

A) Respecto a la vigencia y aplicación del Decreto Ley No. 2.191

a) La ejecución extrajudicial del señor Almonacid Arellano

93. En esta sección la Corte analizará si el crimen cometido en contra del señor Almonacid Arellano podría constituir o no un crimen de lesa humanidad. En este sentido, la Corte debe analizar si para el 17 de septiembre de 1973, fecha en que 
murió el señor Almonacid Arellano, el asesinato constituía un crimen de lesa humanidad, y en qué circunstancias.

94. El desarrollo de la noción de crimen de lesa humanidad se produjo en los inicios del siglo pasado. En el preámbulo del Convenio de la Haya sobre las leyes y costumbres de la guerra terrestre de 1907 (Convenio núm. IV) las potencias contratantes establecieron que "las poblaciones y los beligerantes permanecen bajo la garantía y el régimen de los principios del Derecho de Gentes preconizados por los usos establecidos entre las naciones civilizadas, por las leyes de la humanidad y por las exigencias de la conciencia pública"117. Asimismo, el término "crímenes contra la humanidad y la civilización" fue usado por los gobiernos de Francia, Reino Unido y Rusia el 28 de mayo de 1915 para denunciar la masacre de armenios en Turquía ${ }^{118}$.

95. El asesinato como crimen de lesa humanidad fue codificado por primera vez en el artículo 6.c del Estatuto del Tribunal Militar Internacional de Nuremberg, el cual fue anexado al Acuerdo para el establecimiento de un Tribunal Militar Internacional encargado del juicio y castigo de los principales criminales de guerra del Eje Europeo, firmado en Londres el 8 de agosto de 1945 (el "Acuerdo de Londres"). Poco después, el 20 de diciembre de 1945, la Ley del Consejo de Control No. 10 también consagró al asesinato como un crimen de lesa humanidad en su artículo II.c. De forma similar, el delito de asesinato fue codificado en el artículo 5.c del Estatuto del Tribunal Militar Internacional para el juzgamiento de los principales criminales de guerra del Lejano Oriente (Estatuto de Tokyo), adoptada el 19 de enero de 1946.

96. La Corte, además, reconoce que la Estatuto de Nuremberg jugó un papel significativo en el establecimiento de los elementos que caracterizan a un crimen como de lesa humanidad. Este Estatuto proporcionó la primera articulación de los elementos de dicha ofensa ${ }^{119}$, que se mantuvieron básicamente en su concepción inicial a la fecha de muerte del señor Almonacid Arellano, con la excepción de que los crímenes contra la humanidad pueden ser cometidos en tiempos de paz como en tiempos de guerra ${ }^{120}$.

117 Cfr. Convenio de La Haya del 18 de octubre de 1907 sobre las leyes y costumbres de la guerra terrestre (Convenio núm. IV).

118 Egon Schwelb, Crimes Against Humanity, British Yearbook of Internacional Law. Vol 23, (1946), 178, pág. 181. "[L]os crímenes contra la humanidad y la civilización de los cuales son responsables los miembros del Gobierno turco, así como los agentes implicados en las masacres".

119 Artículo 6.- El Tribunal establecido por el Acuerdo aludido en el Artículo 1 del presente para el enjuiciamiento y condena de los principales criminales de guerra del Eje Europeo estará facultado para juzgar y condenar a aquellas personas que, actuando en defensa de los intereses de los países del Eje Europeo, cometieron los delitos que constan a continuación, ya fuera individualmente o como miembros de organizaciones:

[...]

(c) CRÍMENES CONTRA LA HUMANIDAD: A saber, el asesinato, la exterminación, esclavización, deportación y otros actos inhumanos cometidos contra población civil antes de la guerra o durante la misma; la persecución por motivos políticos, raciales o religiosos en ejecución de aquellos crímenes que sean competencia del Tribunal o en relación con los mismos, constituyan o no una vulneración de la legislación interna de país donde se perpetraron.

120 Cfr. United States Nuremberg Military Tribunal, United States v. Ohlendort, 15 I.L.R. 656 (1948); United States v. Alstotter (1948 Justice Case), in Trials of War Criminals Before the Nuremberg Military Tribunals Under Control Council Law No. 10 Vol. III 956 (U.S. Gov. Printing Office 1951); History of the U.N. War Crimes Commission and the Development of the Laws of War complied by the U.N. War Crimes Commission (1948); Cfr. O.N.U., Principios de Derecho Internacional Reconocidos en el Estatuto del Tribunal de Nuremberg y la Sentencia del Tribunal. Adoptado por la Comisión de Derecho Internacional de las Naciones Unidas en el año 1950, U.N. Doc. A/1316 (1950), part III, párr. 123; artículo I.b de la Convención 
En base a ello, la Corte reconoce que los crímenes contra la humanidad incluyen la comisión de actos inhumanos, como el asesinato, cometidos en un contexto de ataque generalizado o sistemático contra una población civil. Basta que un solo acto ilícito como los antes mencionados sea cometido dentro del contexto descrito, para que se produzca un crimen de lesa humanidad. En este sentido se pronunció el Tribunal Internacional para la ex Yugoslavia en el caso Prosecutor v. Dusko Tadic, al considerar que "un solo acto cometido por un perpetrador en el contexto de un ataque generalizado o sistemático contra la población civil trae consigo responsabilidad penal individual, y el perpetrador no necesita cometer numerosas ofensas para ser considerado responsable"121. Todos estos elementos ya estaban definidos jurídicamente cuando el señor Almonacid Arellano fue ejecutado.

97. Por su parte, el Tribunal Militar Internacional para el Juzgamiento de los Principales Criminales de Guerra (en adelante "el Tribunal de Nuremberg"), el cual tenía jurisdicción para juzgar los crímenes establecidos en el Acuerdo de Londres, indicó que la Estatuto de Nuremberg "es la expresión de derecho internacional existente en el momento de su creación; y en esa extensión es en sí mismo una contribución al derecho internacional"122. Con ello reconoció la existencia de una costumbre internacional, como una expresión del derecho internacional, que proscribía esos crímenes.

98. La prohibición de crímenes contra la humanidad, incluido el asesinato, fue además corroborada por las Naciones Unidas. El 11 de diciembre de 1946 la Asamblea General confirmó “Ios principios de Derecho Internacional reconocidos por el Estatuto del Tribunal de Nuremberg y las sentencias de dicho Tribunal"123. Asimismo, en 1947 la Asamblea General encargó a la Comisión de Derecho Internacional que "formul[ara] los principios de derecho internacional reconocidos por el Estatuto y por las sentencias del Tribunal de Nuremberg"124. Estos principios fueron adoptados en $1950^{125}$. Entre ellos, el Principio VI.c califica al asesinato como un crimen contra la humanidad. De igual forma, la Corte resalta que el artículo 3 común de los Convenios de Ginebra de 1949, de los cuales Chile es parte desde 1950, también prohíbe el "homicidio en todas sus formas" de personas que no participan directamente en las hostilidades.

sobre la imprescriptibilidad de los crímenes de guerra y de los crímenes de la humanidad, adoptada por la Asamblea General de las Naciones Unidas en su Resolución 2391 (XXIII) de 25 de noviembre de 1968.

121 Cfr. Tribunal Penal Internacional para la ex Yugoslavia, caso Prosecutor v. Dusko Tadic, IT-94-1-T, Opinion and Judgement, May 7, 1997, at para. 649. Esto fue posteriormente confirmado por el mismo tribunal en Prosecutor v. Kupreskic, et al, IT-95-16-T, Judgement, January 14, 2000, at para. 550, y Prosecutor v. Kordic and Cerkez, IT-95-14/2-T, Judgement, February 26, 2001, at para. 178.

122 Cfr. Trial of the Major War Criminals before the International Military Tribunal, Nuremberg, Germany, (1947) at 218.

123 Cfr. O.N.U., Confirmación de los principios de Derecho Internacional reconocidos por el Estatuto del Tribunal de Nuremberg adoptada por la Asamblea General de las Naciones Unidas en su Resolución 95(I), Quincuagésima quinta reunión plenaria de 11 de diciembre de 1946.

124 Cfr. O.N.U., Formulación de los principios reconocidos por el Estatuto y por las sentencias del Tribunal de Nuremberg, adoptado por la de la Asamblea General de las Naciones Unidas en su resolución 177 (II), 123aㅡ sesión plenaria de 21 de noviembre de 1947.

125 Cfr. O.N.U., Principios de Derecho Internacional Reconocidos en el Estatuto del Tribunal de Nuremberg y las Sentencias del Tribunal. Adoptado por la Comisión de Derecho Internacional de las Naciones Unidas en el año 1950 (A/CN.4/34). 
99. Basándose en los párrafos anteriores, la Corte encuentra que hay amplia evidencia para concluir que en 1973, año de la muerte del señor Almonacid Arellano, la comisión de crímenes de lesa humanidad, incluido el asesinato ejecutado en un contexto de ataque generalizado o sistemático contra sectores de la población civil, era violatoria de una norma imperativa del derecho internacional. Dicha prohibición de cometer crímenes de lesa humanidad es una norma de ius cogens, y la penalización de estos crímenes es obligatoria conforme al derecho internacional general.

100. La Corte Europea de Derechos Humanos también se pronunció en el mismo sentido en el caso Kolk y Kislyiy v. Estonia. En este caso los señores Kolk y Kislyiy cometieron crímenes de lesa humanidad en 1949 y fueron juzgados y sancionados por ellos en las cortes de Estonia en el año 2003. La Corte Europea indicó que aún cuando los actos cometidos por esas personas pudieron haber sido legales por la ley doméstica que imperaba en ese entonces, las cortes de Estonia consideraron que constituían crímenes de lesa humanidad bajo el derecho internacional al momento de su comisión, y que no encontraba motivo alguno para llegar a una conclusión diferente ${ }^{126}$.

101. Por otra lado, esta Corte enfatiza que para el año 1998, cuando se confirmó la aplicación del Decreto Ley No. 2.191 en el presente caso (supra párr. 82.21), ya se

126 Cfr. ECHR, Case Kolk and Kislyiy v. Estonia, Judgment of 17 January 2006. Applications Nos. $23052 / 04$ and 24018/04.

[Los señores Kolk y Kislyiy] señalaron que los actos en relación a los cuales fueron condenados sucedieron en el año 1949 en el territorio de [la República Socialista Soviética de] Estonia. En el momento material de los hechos era aplicable en el territorio de Estonia el Código Criminal de 1946 de la República Socialista Federal Rusa. Este código no incluía crímenes de lesa humanidad. La responsabilidad para crímenes de lesa humanidad no fue establecida en Estonia sino hasta el 9 de Noviembre de 1994 [...].

La Corte observa, primero, que Estonia perdió su independencia como consecuencia del Pacto de no Agresión entre Alemania y la Unión de Repúblicas Socialistas Soviéticas (también conocido como el "Pacto de Molotov-Ribbentrop"), adoptado el 23 de agosto de 1939, y sus protocolos adicionales secretos. [...] El régimen totalitario comunista de la Unión Soviética condujo acciones sistemáticas y a gran escala en contra de la población de Estonia, incluyendo, por ejemplo, la deportación de cerca de 10.000 personas el 14 de junio de 1941 y más de 20.000 el 25 de marzo de 1949.

[...]

La Corte observa que la deportación de población civil estaba expresamente reconocida por el Estatuto del Tribunal de Nuremberg de 1945 como un crimen de lesa humanidad (artículo 6 (c)). Aun cuando el Tribunal de Nuremberg fue establecido para perseguir a los principales criminales de guerra de los países del Eje Europeo por los delitos cometidos antes o durante la Segunda Guerra Mundial, la Corte observa que la validez universal de los principios sobre los crímenes de lesa humanidad fueron confirmados subsiguientemente por, inter alia, la Resolución No. 95 de la Asamblea General de la Organización de las Naciones Unidas (11 de diciembre de 1946) y luego por la Comisión de Derecho Internacional. Por consiguiente, la responsabilidad por crímenes de lesa humanidad no puede ser limitada únicamente a nacionales de algunos países y únicamente a actos cometidos en el marco temporal de la Segunda Guerra Mundial. [...]

[...]

La Corte observa que aun cuando los actos cometidos por [los señores Kolk y Kislyiy] pudieron haber sido considerados lícitos bajo las leyes soviéticas en ese momento, las cortes de Estonia los consideraron bajo el derecho internacional como crímenes de lesa humanidad, en el momento de su comisión. La Corte no ve razón para llegar a una conclusión diferente. [...] Por lo tanto, la Corte considera que las alegaciones de los recurrentes no tienen bases suficientes para señalar que sus actos no constituían crímenes de lesa humanidad en el momento de su consumación [...].

Además, ninguna prescripción limitante es aplicable a los crímenes de lesa humanidad, independientemente de la fecha de su comisión. [...] La Corte no encuentra razón alguna para poner en duda la interpretación y aplicación de la ley doméstica que las cortes de Estonia efectuaron a la luz del derecho internacional pertinente. En conclusión se tiene que [las] alegaciones [de los peticionarios] son manifiestamente infundadas y deben ser rechazadas. 
habían adoptado los Estatutos de los Tribunales Penales Internacionales para la ex Yugoslavia (25 de mayo de 1993) y Ruanda (9 de noviembre de 1994), cuyos artículos 5 y 3 , respectivamente, reafirman que el asesinato constituye un grave crimen de derecho internacional. Este criterio fue corroborado por el artículo 7 del Estatuto de Roma (17 de julio de 1998) que creó la Corte Penal Internacional.

102. Ahora bien, corresponde al Tribunal analizar si las circunstancias en que se produjo la muerte del señor Almonacid Arellano podrían constituir un crimen de lesa humanidad, conforme fuera definido para el año 1973 (supra párr. 99).

103. Como se desprende del capítulo de Hechos Probados (supra párr. 82.3 a 82.7), desde el 11 de septiembre de 1973 hasta el 10 de marzo de 1990 gobernó en Chile un dictadura militar que dentro de una política de Estado encaminada a causar miedo, atacó masiva y sistemáticamente a sectores de la población civil considerados como opositores al régimen, mediante una serie de graves violaciones a los derechos humanos y al derecho internacional, entre las que se cuentan al menos 3.197 víctimas de ejecuciones sumarias y desapariciones forzadas, y 33.221 detenidos, de quienes una inmensa mayoría fue víctima de tortura (supra párr. 82.5). De igual forma, la Corte tuvo por probado que la época más violenta de todo este período represivo correspondió a los primeros meses del gobierno de facto. Cerca del $57 \%$ de todas las muertes y desapariciones, y el $61 \%$ de las detenciones ocurrieron en los primeros meses de la dictadura. La ejecución del señor Almonacid Arellano precisamente se produjo en esa época.

104. En vista de lo anterior, la Corte considera que existe suficiente evidencia para razonablemente sostener que la ejecución extrajudicial cometida por agentes estatales en perjuicio del señor Almonacid Arellano, quien era militante del Partido Comunista, candidato a regidor del mismo partido, secretario provincial de la Central Unitaria de Trabajadores y dirigente gremial del Magisterio (SUTE), todo lo cual era considerado como una amenaza por su doctrina, cometida dentro de un patrón sistemático y generalizado contra la población civil, es un crimen de lesa humanidad.

\section{b) Imposibilidad de amnistiar los crímenes de lesa humanidad}

105. Según el corpus iuris del Derecho Internacional, un crimen de lesa humanidad es en sí mismo una grave violación a los derechos humanos y afecta a la humanidad toda. En el caso Prosecutor v. Erdemovic el Tribunal Internacional para la ex Yugoslavia indicó que

[I]os crímenes de lesa humanidad son serios actos de violencia que dañan a los seres humanos al golpear lo más esencial para ellos: su vida, su libertad, su bienestar físico, su salud y/o su dignidad. Son actos inhumanos que por su extensión y gravedad van más allá de los límites de lo tolerable para la comunidad internacional, la que debe necesariamente exigir su castigo. Pero los crímenes de lesa humanidad también trascienden al individuo, porque cuando el individuo es agredido, se ataca y se niega a la humanidad toda. Por eso lo que caracteriza esencialmente al crimen de lesa humanidad es el concepto de la humanidad como víctima ${ }^{127}$.

127 Cfr. Tribunal Penal Internacional para la ex Yugoslavia, Prosecutor v. Erdemovic, Case No. IT-96-22T, Sentencing Judgment, November 29, 1996, at para. 28.

Crimes against humanity are serious acts of violence which harm human beings by striking what is most essential to them: their life, liberty, physical welfare, health, and or dignity. They are inhumane acts that by their extent and gravity go beyond the limits tolerable to the international community, which must perforce demand their punishment. But crimes against humanity also transcend the individual because when the individual is assaulted, humanity 
106. Al ser el individuo y la humanidad las víctimas de todo crimen de lesa humanidad, la Asamblea General de las Naciones desde $1946^{128}$ ha sostenido que los responsables de tales actos deben ser sancionados. Resaltan al respecto las Resoluciones 2583 (XXIV) de 1969 y 3074 (XXVIII) de 1973. En la primera, la Asamblea General sostuvo que la "investigación rigurosa" de los crímenes de guerra y los crímenes de lesa humanidad, así como la sanción de sus responsables, "son un elemento importante para prevenir esos crímenes y proteger los derechos humanos y las libertades fundamentales, y para fomentar la confianza, estimular la cooperación entre pueblos y contribuir a la paz y la seguridad internacionales"129. En la segunda Resolución, la Asamblea general afirmó:

Los crímenes de guerra y los crímenes de lesa humanidad, dondequiera y cualquiera que sea la fecha en que se hayan cometido, serán objeto de una investigación, y las personas contra las que existan pruebas de culpabilidad en la comisión de tales crímenes serán buscadas, detenidas, enjuiciadas y, en caso de ser declaradas culpables, castigadas.

$[\ldots]$

Los Estados no adoptarán medidas legislativas ni tomarán medidas de otra índole que puedan menoscabar las obligaciones internacionales que hayan contraído con respecto a la identificación, la detención, la extradición y el castigo de los culpables de crímenes de guerra o de crímenes de lesa humanidad ${ }^{130}$.

107. I gualmente, las Resoluciones 827 y 955 del Consejo de Seguridad de las Naciones Unidas ${ }^{131}$, junto con los Estatutos de los Tribunales para exYugoslavia (Artículo 29) y Ruanda (Artículo 28), imponen una obligación a todos los Estados miembros de las Naciones Unidas de cooperar plenamente con los Tribunales en la investigación y persecución de personas acusadas de haber cometido serias violaciones de Derecho Internacional, incluidos crímenes contra la humanidad. Asimismo, el

comes under attack and is negated. It is therefore the concept of humanity as victim which essentially characterises crimes against humanity.

128 Cfr. O.N.U., Extradición y castigo de criminales de guerra, adoptada por la Asamblea General de las Naciones Unidas en su resolución 3 (I) de 13 de febrero de 1946; Confirmación de los principios de derecho internacional reconocidos por el Estatuto del Tribunal de Nuremberg, adoptada por la Asamblea General de las Naciones Unidas en su resolución 95 (I) de 11 de diciembre de 1946; Extradición de delincuentes de guerra y traidores, adoptado por la Asamblea General de las Naciones Unidas en su resolución 170 (II) de 31 de octubre de 1947; Cuestión del Castigo de los criminales de guerra y de las personas que hayan cometido crímenes de lesa humanidad, adoptado por la Asamblea General de las Naciones Unidas en su resolución 2338 (XXII) de 18 de diciembre de 1967; Convención sobre la imprescriptibilidad de los crímenes de guerra y de los crímenes de la humanidad, adoptada por la Asamblea General de las Naciones Unidas en su Resolución 2391 (XXIII) de 25 de noviembre de 1968; Cuestión del castigo de los criminales de guerra y de las personas que hayan cometido crímenes de lesa Humanidad, adoptada por la Asamblea General de las Naciones Unidas en su Resolución 2712 (XXV) de 14 de diciembre de 1970; Cuestión del castigo de los criminales de guerra y de las personas que hayan cometido crímenes de lesa humanidad, adoptada por la Asamblea General de las Naciones Unidas en su Resolución 2840 (XXVI) de 18 de diciembre de 1971, y Prevención del delito y la lucha contra la delincuencia, adoptada por la Asamblea General de las Naciones Unidas en su Resolución 3020 (XXVII) de 18 de diciembre de 1972.

129 Cfr. O.N.U., Cuestión del castigo de los criminales de guerra y de las personas que hayan cometido crímenes de lesa Humanidad, adoptada por la Asamblea General de las Naciones Unidas en su resolución 2583 (XXIV) de 15 de diciembre de 1969.

130 Cfr. O.N.U., Principios de cooperación internacional en la identificación, detención, extradición y castigo de los culpables de crímenes de guerra, o de crímenes de lesa humanidad adoptados por la Asamblea General de las Naciones Unidas en su resolución 3074 (XXVIII) 3 de diciembre de 1973.

131 Cfr. O.N.U., Resolución del Consejo de Seguridad, S/RES/827 para el establecimiento del Tribunal Penal Internacional para la ex Yugoslavia de 25 de marzo de 1993; y Resolución del Consejo de Seguridad, S/RES/955 para el establecimiento del Tribunal Penal Internacional para Ruanda 8 de noviembre de 1994. 
Secretario General de las Naciones Unidas ha señalado que en vista de las normas y los principios de las Naciones Unidas, los acuerdos de paz aprobados por ella nunca pueden prometer amnistías por crímenes de lesa humanidad ${ }^{132}$.

108. La adopción y aplicación de leyes que otorgan amnistía por crímenes de lesa humanidad impide el cumplimiento de las obligaciones señaladas. El Secretario General de las Naciones Unidas, en su informe sobre el establecimiento del Tribunal Especial para Sierra Leona, afirmó que

[a] unque reconocen que la amnistía es un concepto jurídico aceptado y una muestra de paz y reconciliación al final de una guerra civil o de un conflicto armado interno, las Naciones Unidas mantienen sistemáticamente la posición de que la amnistía no puede concederse respecto de crímenes internacionales como el genocidio, los crímenes de lesa humanidad o las infracciones graves del derecho internacional humanitario ${ }^{133}$.

109. El Secretario General también informó que no se reconoció efectos jurídicos a la amnistía concedida en Sierra Leona, "dada su ilegalidad con arreglo al derecho internacional"134. En efecto, el artículo 10 del Estatuto del Tribunal Especial para Sierra Leona dispuso que la amnistía concedida a personas acusadas de crímenes de lesa humanidad, infracciones al artículo 3 común de los Convenios de Ginebra y Protocolo Adicional $\mathrm{II}^{135}$, así como otras infracciones graves del derecho internacional humanitario, "no constituirá un impedimento para [su] procesamiento".

110. La obligación conforme al derecho internacional de enjuiciar y, si se les declara culpables, castigar a los perpetradores de determinados crímenes internacionales, entre los que se cuentan los crímenes de lesa humanidad, se desprende de la obligación de garantía consagrada en el artículo 1.1 de la Convención Americana. Esta obligación implica el deber de los Estados Partes de organizar todo el aparato gubernamental y, en general, todas las estructuras a través de las cuales se manifiesta el ejercicio del poder público, de manera tal que sean capaces de asegurar jurídicamente el libre y pleno ejercicio de los derechos humanos. Como consecuencia de esta obligación los Estados deben prevenir, investigar y sancionar toda violación de los derechos reconocidos por la Convención y procurar, además, el restablecimiento, si es posible, del derecho conculcado y, en su caso, la reparación de los daños producidos por la violación de los derechos humanos. Si el aparato del Estado actúa de modo que tal violación quede impune y no se restablezca, en cuanto sea posible, a la víctima en la plenitud de sus derechos, puede afirmarse que ha incumplido el deber de garantizar su libre y pleno ejercicio a las personas sujetas a su jurisdicción ${ }^{136}$.

111. Los crímenes de lesa humanidad producen la violación de una serie de derechos inderogables reconocidos en la Convención Americana, que no pueden quedar

132 Cfr. O.N.U., Informe del Secretario General sobre el Estado de derecho y la justicia de transición en las sociedades que sufren o han sufrido conflictos, S/2004/616 de 3 de agosto de 2004, párr. 10.

133 Cfr. O.N.U., Informe del Secretario General sobre el establecimiento de un Tribunal para Sierra Leona, S/2000/915 de 4 de octubre de 2000, párr. 22.

134 Cfr. O.N.U., Informe del Secretario General sobre el establecimiento de un tribunal para Sierra Leona, S/2000/915, 4 de octubre de 2000, párr. 24.

135 Cfr. O.N.U., Protocolo adicional a los Convenios de Ginebra del 12 de agosto de 1949 relativo a la protección de las víctimas de los conflictos armados sin carácter internacional (Protocolo II).

136 Cfr. Caso Velásquez Rodríguez. Sentencia de 29 de julio de 1988. Serie C No. 4, párr. 166, y Caso Godínez Cruz. Sentencia de 20 de enero de 1989. Serie C No. 5, párr. 175. 
impunes. En reiteradas oportunidades el Tribunal ha señalado que el Estado tiene el deber de evitar y combatir la impunidad, que la Corte ha definido como "la falta en su conjunto de investigación, persecución, captura, enjuiciamiento y condena de los responsables de las violaciones de los derechos protegidos por la Convención Americana"137. Asimismo, la Corte ha determinado que la investigación debe ser realizada por todos los medios legales disponibles y orientada a la determinación de la verdad y la investigación, persecución, captura, enjuiciamiento y castigo de todos los responsables intelectuales y materiales de los hechos, especialmente cuando están o puedan estar involucrados agentes estatales ${ }^{138}$. Al respecto, este Tribunal ha señalado que no pueden considerarse efectivos aquellos recursos que, por las condiciones generales del país o incluso por las circunstancias particulares de un caso dado, resulten ilusorios ${ }^{139}$.

\title{
112. Este Tribunal ya había señalado en el Caso Barrios Altos que
}

\begin{abstract}
son inadmisibles las disposiciones de amnistía, las disposiciones de prescripción y el establecimiento de excluyentes de responsabilidad que pretendan impedir la investigación y sanción de los responsables de las violaciones graves de los derechos humanos tales como la tortura, las ejecuciones sumarias, extralegales o arbitrarias y las desapariciones forzadas, todas ellas prohibidas por contravenir derechos inderogables reconocidos por el Derecho Internacional de los Derechos Humanos ${ }^{140}$.
\end{abstract}

113. Resulta útil destacar también que el propio Estado en el presente caso reconoció que en "principio, las leyes de amnistía o auto amnistía son contrarias a las normas de derecho internacional de los derechos humanos"141.

114. Por las consideraciones anteriores, la Corte estima que los Estados no pueden sustraerse del deber de investigar, determinar y sancionar a los responsables de los crímenes de lesa humanidad aplicando leyes de amnistía u otro tipo de normativa interna. Consecuentemente, los crímenes de lesa humanidad son delitos por los que no se puede conceder amnistía.

c) La vigencia del Decreto Ley No. 2.191 a partir del 21 de agosto de 1990

115. Ya que se ha establecido que el crimen cometido en contra del señor Almonacid Arellano es un crimen de lesa humanidad, y que los crímenes de lesa humanidad no pueden ser amnistiados, corresponde al Tribunal analizar si el Decreto Ley No. 2.191 amnistía ese crimen y si, de darse ese supuesto, el Estado ha dejado de cumplir su obligación derivada del artículo 2 de la Convención por mantener vigente esa normativa.

137 Cfr Caso de las Masacres de Ituango, supra nota 14, párr. 299; Caso de la "Masacre de Mapiripán", Sentencia de 15 de septiembre de 2005. Serie C No. 134, párr. 237; Caso de la Comunidad Moiwana, Sentencia de 15 de septiembre de 2005. Serie C No. 134, párr. 203.

138 Cfr. Caso Ximenes Lopes, supra nota 14, párr. 148; Caso Baldeón García, supra nota 14, párr. 94; y Caso de la Masacre de Pueblo Bello, Sentencia de 31 de enero de 2006. Serie C No. 140, párr. 143.

139 Cfr. Caso Baldeón García, supra nota 14, párr. 144; Caso 19 Comerciantes, Sentencia de 5 de julio de 2004. Serie C No. 109, párr. 192; y Caso Baena Ricardo y otros. Competencia. Sentencia de 28 de noviembre de 2003. Serie C No. 104, párr. 77.

140 Cfr. Caso Barrios Altos. Sentencia de 14 de marzo de 2001. Serie C No. 75. Párr. 41.

141 Cfr. alegatos finales escritos del Estado (expediente de fondo, Tomo III, folio 723). 
116. El artículo 1 del Decreto Ley No. 2.191 (supra párr. 82.10) concede una amnistía general a todos los responsables de "hechos delictuosos" cometidos desde el 11 de septiembre de 1973 al 10 de marzo de 1978. Por su parte, el artículo 3 de ese Decreto Ley excluye de la amnistía una serie de delitos ${ }^{142}$. La Corte nota que el crimen de lesa humanidad de asesinato no figura en el listado del artículo 3 del citado Decreto Ley. Así también lo entendieron las cortes chilenas que conocieron el presente caso, al aplicarlo (supra párr. 82.20 y 82.21). De igual forma, este Tribunal, aún cuando no ha sido llamado a pronunciarse en este caso sobre otros crímenes de lesa humanidad, llama la atención respecto a que tampoco se encuentran excluidos de la amnistía crímenes de lesa humanidad como la desaparición forzada, la tortura, el genocidio, entre otros.

\section{Esta Corte ha afirmado en varias oportunidades que}

[e]n el derecho de gentes, una norma consuetudinaria prescribe que un Estado que ha celebrado un convenio internacional, debe introducir en su derecho interno las modificaciones necesarias para asegurar la ejecución de las obligaciones asumidas. Esta norma aparece como válida universalmente y ha sido calificada por la jurisprudencia como un principio evidente ("principe allant de soi"; Echange des populations grecques et turques, avis consultatif, 1925, C.P.J.I., série B, no. 10, p. 20). En este orden de ideas, la Convención Americana establece la obligación de cada Estado Parte de adecuar su derecho interno a las disposiciones de dicha Convención, para garantizar los derechos en ella consagrados ${ }^{143}$.

118. A la luz del artículo 2 de la Convención, tal adecuación implica la adopción de medidas en dos vertientes, a saber: i) la supresión de las normas y prácticas de cualquier naturaleza que entrañen violación a las garantías previstas en la Convención, y ii) la expedición de normas y el desarrollo de prácticas conducentes a la efectiva observancia de dichas garantías ${ }^{144}$. Es necesario reafirmar que la obligación de la primera vertiente sólo se satisface cuando efectivamente se realiza la reforma ${ }^{145}$.

119. Leyes de amnistía con las características descritas (supra párr. 116) conducen a la indefensión de las víctimas y a la perpetuación de la impunidad de los crímenes de lesa humanidad, por lo que son manifiestamente incompatibles con la letra y el espíritu de la Convención Americana e indudablemente afectan derechos consagrados en ella. Ello constituye per se una violación de la Convención y genera responsabilidad

142 De acuerdo al Artículo 3 del Decreto Ley No. 2.191 no quedaron comprendidos en la amnistía “las personas respecto de las cuales hubiere acción penal vigente en su contra por los delitos de parricidio, infanticidio, robo con fuerza en las cosas, o con violencia o intimidación en las personas, elaboración o tráfico de estupefacientes, sustracción de menores de edad, corrupción de menores, incendios y otros estragos; violación, estupro, incesto, manejo en estado de ebriedad, malversación de caudales o efectos públicos, fraudes y exacciones ilegales, estafas y otros engaños, abusos deshonestos, delitos contemplados en el decreto ley número 280, de 1974, y sus posteriores modificaciones; cohecho, fraude y contrabando aduanero y delitos previstos en el Código Tributario".

143 Cfr. Caso Garrido y Baigorria. Reparaciones (art. 63.1 Convención Americana sobre Derechos Humanos). Sentencia de 27 de agosto de 1998. Serie C No. 39, párr. 68; Caso Baena Ricardo y otros. Sentencia del 2 de febrero de 2001. Serie C № 72, párr. 179.

144 Cfr. Caso Ximenes Lopes, supra nota 14, párr. 83; Caso Gómez Palomino. Sentencia de 22 de noviembre de 2005. Serie C No. 136, párr. 91; y Caso de la Masacre de Mapiripán, supra nota 137, párr. 109.

145 Cfr. Caso Raxcacó Reyes. Sentencia de 15 de septiembre de 2005. Serie C No. 133. párr. 87; Caso Comunidad indígena Yakye Axa, supra nota 5, párr. 100; y Caso Caesar. Sentencia de 11 de marzo de 2005. Serie C No. 123, párrs. 91 y 93. 
internacional del Estado ${ }^{146}$. En consecuencia, dada su naturaleza, el Decreto Ley No. 2.191 carece de efectos jurídicos y no puede seguir representando un obstáculo para la investigación de los hechos que constituyen este caso, ni para la identificación y el castigo de los responsables, ni puede tener igual o similar impacto respecto de otros casos de violación de los derechos consagrados en la Convención Americana acontecidos en Chile ${ }^{147}$.

120. Por otro lado, si bien la Corte nota que el Decreto Ley No. 2.191 otorga básicamente una autoamnistía, puesto que fue emitido por el propio régimen militar, para sustraer de la acción de la justicia principalmente sus propios crímenes, recalca que un Estado viola la Convención Americana cuando dicta disposiciones que no están en conformidad con las obligaciones dentro de la misma; el hecho de que esas normas se hayan adoptado de acuerdo con el ordenamiento jurídico interno o contra él, "es indiferente para estos efectos"148. En suma, esta Corte, más que al proceso de adopción y a la autoridad que emitió el Decreto Ley No. 2.191, atiende a su ratio legis: amnistiar los graves hechos delictivos contra el derecho internacional cometidos por el régimen militar.

121. El Estado, desde que ratificó la Convención Americana el 21 de agosto de 1990, ha mantenido vigente el Decreto Ley No. 2.191 por 16 años, en inobservancia de las obligaciones consagradas en aquella. Que tal Decreto Ley no esté siendo aplicado por el Poder Judicial chileno en varios casos a partir de 1998, si bien es un adelanto significativo y la Corte lo valora, no es suficiente para satisfacer las exigencias del artículo 2 de la Convención en el presente caso. En primer lugar porque, conforme a lo señalado en los párrafos anteriores, el artículo 2 impone una obligación legislativa de suprimir toda norma violatoria a la Convención y, en segundo lugar, porque el criterio de las cortes internas puede cambiar, decidiéndose aplicar nuevamente una disposición que para el ordenamiento interno permanece vigente.

122. Por tales razones, la Corte encuentra que el Estado ha incumplido con los deberes impuestos por el artículo 2 de la Convención Americana, por mantener formalmente dentro de su ordenamiento un Decreto Ley contrario a la letra y espíritu de la misma.

d) La aplicación del Decreto Ley No. 2.191

123. La descrita obligación legislativa del artículo 2 de la Convención tiene también la finalidad de facilitar la función del Poder Judicial de tal forma que el aplicador de la ley tenga una opción clara de cómo resolver un caso particular. Sin embargo, cuando el Legislativo falla en su tarea de suprimir y/o no adoptar leyes contrarias a la Convención Americana, el Judicial permanece vinculado al deber de garantía establecido en el artículo 1.1 de la misma y, consecuentemente, debe abstenerse de aplicar cualquier normativa contraria a ella. El cumplimiento por parte de agentes o funcionarios del Estado de una ley violatoria de la Convención produce responsabilidad internacional del Estado, y es un principio básico del derecho de la responsabilidad

146 Cfr. Caso Barrios Altos. Interpretación de la Sentencia de Fondo. (art. 67 Convención Americana sobre Derechos Humanos). Sentencia de 3 de septiembre de 2001. Serie C No. 83, párr. 18.

147 Cfr. Caso Barrios Altos, supra nota 140, párr. 44.

148 Cfr. Ciertas Atribuciones de la Comisión Interamericana de Derechos Humanos (arts. 41, 42, 44, 46, 47, 50 y 51 Convención Americana sobre Derechos Humanos). Opinión Consultiva OC-13/93 del 16 de julio de 1993. Serie A No. 13, párr. 26. 
internacional del Estado, recogido en el Derecho Internacional de los Derechos Humanos, en el sentido de que todo Estado es internacionalmente responsable por actos u omisiones de cualesquiera de sus poderes u órganos en violación de los derechos internacionalmente consagrados, según el artículo 1.1 de la Convención Americana ${ }^{149}$.

124. La Corte es consciente que los jueces y tribunales internos están sujetos al imperio de la ley y, por ello, están obligados a aplicar las disposiciones vigentes en el ordenamiento jurídico. Pero cuando un Estado ha ratificado un tratado internacional como la Convención Americana, sus jueces, como parte del aparato del Estado, también están sometidos a ella, lo que les obliga a velar porque los efectos de las disposiciones de la Convención no se vean mermadas por la aplicación de leyes contrarias a su objeto y fin, y que desde un inicio carecen de efectos jurídicos. En otras palabras, el Poder Judicial debe ejercer una especie de "control de convencionalidad" entre las normas jurídicas internas que aplican en los casos concretos y la Convención Americana sobre Derechos Humanos. En esta tarea, el Poder Judicial debe tener en cuenta no solamente el tratado, sino también la interpretación que del mismo ha hecho la Corte Interamericana, intérprete última de la Convención Americana.

125. En esta misma línea de ideas, esta Corte ha establecido que "[s] egún el derecho internacional las obligaciones que éste impone deben ser cumplidas de buena fe y no puede invocarse para su incumplimiento el derecho interno" ${ }^{150}$. Esta regla ha sido codificada en el artículo 27 de la Convención de Viena sobre el Derecho de los Tratados de 1969.

126. En el presente caso, el Poder Judicial aplicó el Decreto Ley No. 2.191 (supra párr. 82.20 y 82.21), lo que tuvo como efecto inmediato el cese de las investigaciones y el archivo del expediente, dejando en la impunidad a los responsables de la muerte del señor Almonacid Arellano. De acuerdo a lo anterior, se impidió a los familiares que ejercieran el derecho a ser oídos por un tribunal competente, independiente e imparcial, a través de un recurso efectivo y adecuado que repare las violaciones cometidas en perjuicio de su ser querido y les permitiera conocer la verdad.

127. Conforme a la jurisprudencia de este Tribunal,

a la luz de las obligaciones generales consagradas en los artículos 1.1 y 2 de la Convención Americana, los Estados Partes tienen el deber de tomar las providencias de toda índole para que nadie sea sustraído de la protección judicial y del ejercicio del derecho a un recurso sencillo y eficaz, en los términos de los artículos 8 y 25 de la Convención. Es por ello que los Estados Partes en la Convención que adopten leyes que tengan este efecto, como lo son las leyes de autoamnistía, incurren en una violación de los artículos 8 y 25 en concordancia con los artículos 1.1 y 2 de la Convención. Las leyes de autoamnistía conducen a la indefensión de las víctimas y a la perpetuación de la impunidad, por lo que son manifiestamente incompatibles con la letra y el espíritu de la Convención Americana. Este tipo de leyes impide la identificación de los individuos responsables de violaciones a derechos humanos, ya que se obstaculiza la investigación y el acceso a la justicia e impide a las víctimas y a sus familiares conocer la verdad y recibir la reparación correspondiente $e^{151}$.

149 Cfr. Caso Ximenes Lopes, supra nota 14, párr. 172; y Caso Baldeón García, supra nota 14, párr. 140.

150 Cfr. Responsabilidad Internacional por Expedición y Aplicación de Leyes Violatorias de la Convención (Arts. 1 y 2 Convención Americana Sobre Derechos Humanos), Opinión Consultiva OC-14/94 del 9 de diciembre de 1994, Serie A No. 14, párr. 35.

151 Cfr. Caso Barrios Altos, supra nota 140, párr. 43. 
128. Por lo tanto, la Corte considera que la aplicación del Decreto Ley No. 2.191 desconoció los deberes impuestos por el artículo 1.1 de la Convención Americana en violación de los derechos de la señora Elvira del Rosario Gómez Olivares y de los señores Alfredo, Alexis y José Luis Almonacid Gómez consagrados en los artículos 8.1 y 25 de la Convención, de todo lo cual Chile es internacionalmente responsable.

129. El Tribunal, como conclusión de todo lo señalado en esta sección A), considera que el asesinato del señor Almonacid Arellano formó parte de una política de Estado de represión a sectores de la sociedad civil, y representa sólo un ejemplo del gran conjunto de conductas ilícitas similares que se produjeron durante esa época. El ilícito cometido en contra del señor Almonacid Arellano no puede amnistiarse conforme a las reglas básicas del derecho internacional, puesto que constituye un crimen de lesa humanidad. El Estado incumplió su obligación de adecuar su derecho interno a efectos de garantizar los derechos establecidos en la Convención Americana, porque mantuvo y mantiene en vigencia el Decreto Ley No. 2.191, el que no excluye a los crímenes de lesa humanidad de la amnistía general que otorga. Finalmente, el Estado violó el derecho a las garantías judiciales y a la protección judicial, e incumplió con su deber de garantía, en perjuicio de los familiares del señor Almonacid Arellano, porque aplicó el Decreto Ley No. 2.191 al presente caso.

\section{B) Respecto a la jurisdicción militar}

130. La Convención Americana en su artículo 8.1 establece que toda persona tiene el derecho de ser oída por un juez o tribunal competente, independiente e imparcial. Así, esta Corte ha señalado que "toda persona sujeta a un juicio de cualquier naturaleza ante un órgano del Estado deberá contar con la garantía de que dicho órgano sea imparcial y actúe en los términos del procedimiento legalmente previsto para el conocimiento y la resolución del caso que se le somete"152.

131. El Tribunal ha establecido que en un Estado democrático de derecho la jurisdicción penal militar ha de tener un alcance restrictivo y excepcional y estar encaminada a la protección de intereses jurídicos especiales, vinculados con las funciones que la ley asigna a las fuerzas militares. Por ello, sólo se debe juzgar a militares por la comisión de delitos o faltas que por su propia naturaleza atenten contra bienes jurídicos propios del orden militar ${ }^{153}$. Al respecto, la Corte ha dicho que "[c]uando la justicia militar asume competencia sobre un asunto que debe conocer la justicia ordinaria, se ve afectado el derecho al juez natural $y$, a fortiori, el debido proceso", el cual, a su vez, se encuentra íntimamente ligado al propio derecho de acceso a la justicia ${ }^{154}$.

152 Cfr. Caso Herrera Ulloa, supra nota 13. párr. 169; y Caso del Tribunal Constitucional. Sentencia de 31 de enero de 2001. Serie C No. 71, párr. 77.

153 Cfr Caso Palamara Iribarne. Sentencia de 22 de noviembre de 2005. Serie C No. 135, párr. 124; Caso de la "Masacre de Mapiripán", supra nota 137, párr. 202; y Caso 19 Comerciantes, supra nota 139, párr. 165.

154 Cfr. Caso Palamara Iribarne, supra nota 153, párr. 143; Caso 19 Comerciantes, supra nota 139, párr. 167; y Caso Las Palmeras. Sentencia de 6 de diciembre de 2001. Serie C No. 90, párr. 52. 
132. En el presente caso, la Corte ha encontrado probado que el 27 de septiembre de 1996 el Segundo Juzgado Militar de Santiago solicitó al Primer Juzgado del Crimen de Rancagua que se inhibiera de seguir conociendo la causa porque las personas investigadas al momento en que ocurrieron los hechos estaban sujetas al fuero militar (supra párr. 82.16). Como resultado de lo anterior, la Corte Suprema chilena resolvió el conflicto de competencia a favor de la Jurisdicción Militar (supra párr. 82.17), la que finalmente concluyó las investigaciones del presente caso aplicando el Decreto Ley de autoamnistía (supra párr. 82.20 y 82.21).

133. En vista de lo anterior, la Corte declara que el Estado violó el Artículo 8.1 de la Convención Americana, en conjunto con el artículo 1.1 de la misma, por otorgar competencia a la jurisdicción militar para que conozca el presente caso, ya que ésta no cumple con los estándares de competencia, independencia e imparcialidad anteriormente expuestos.

\section{IX \\ REPARACI ONES \\ (aplicación del Artí culo 63.1 de la Convención Americana)}

Obligación de Reparar

134. De conformidad con el análisis realizado en el capítulo precedente, la Corte declaró que Chile es responsable por la violación de los derechos consagrados en los artículos 8.1 y 25 de la Convención Americana, y por el incumplimiento de las obligaciones que se derivan de los artículos 1.1 y 2 del mismo instrumento internacional. La Corte ha establecido, en varias ocasiones, que toda violación de una obligación internacional que haya producido un daño comporta el deber de repararlo adecuadamente ${ }^{155}$. A tales efectos, el artículo 63.1 de la Convención Americana establece que:

[c]uando decida que hubo violación de un derecho o libertad protegidos en [la] Convención, la Corte dispondrá que se garantice al lesionado en el goce de su derecho o libertad conculcados. Dispondrá asimismo, si ello fuera procedente, que se reparen las consecuencias de la medida o situación que ha configurado la vulneración de esos derechos y el pago de una justa indemnización a la parte lesionada.

135. Tal como lo ha señalado la Corte, el artículo 63.1 de la Convención Americana refleja una norma consuetudinaria que constituye uno de los principios fundamentales del Derecho Internacional contemporáneo sobre la responsabilidad de los Estados. De esta manera, al producirse un hecho ilícito imputable a un Estado, surge de inmediato la responsabilidad internacional de éste por la violación de la norma internacional de que se trata, con el consecuente deber de reparación y de hacer cesar las consecuencias de la violación ${ }^{156}$.

136. La reparación del daño ocasionado por la infracción de una obligación internacional requiere, siempre que sea posible, la plena restitución (restitutio in

155 Cfr. Caso Montero Aranguren y otros. Sentencia de 5 de julio de 2006. Serie C No. 150, párr. 115; Caso Ximenes Lopes, supra nota 14, párr. 207; y Caso de las Masacres de Ituango, supra nota 14, párr. 345.

156 Cfr. Caso Montero Aranguren y otros, supra nota 155, párr. 116; Caso Ximenes Lopes, supra nota 14, párr. 208; y Caso de las Masacres de Ituango, supra nota 14, párr. 346. 
integrum), la cual consiste en el restablecimiento de la situación anterior a la violación. De no ser esto posible, cabe al tribunal internacional determinar una serie de medidas para que, además de garantizar el respeto de los derechos conculcados, se reparen las consecuencias que produjeron las infracciones y se establezca el pago de una indemnización como compensación por los daños ocasionados. Es necesario añadir las medidas de carácter positivo que el Estado debe adoptar para asegurar que no se repitan hechos lesivos como los ocurridos en el presente caso. La obligación de reparar, que se regula en todos los aspectos (alcance, naturaleza, modalidades y determinación de los beneficiarios) por el Derecho Internacional, no puede ser modificada o incumplida por el Estado obligado, invocando disposiciones de su derecho interno ${ }^{157}$.

137. Las reparaciones, como el término lo indica, consisten en las medidas que tienden a hacer desaparecer los efectos de las violaciones cometidas. Su naturaleza y su monto dependen del daño ocasionado en los planos tanto material como inmaterial. Las reparaciones no pueden implicar ni enriquecimiento ni empobrecimiento para la víctima o sus sucesores ${ }^{158}$.

138. En el capítulo de Hechos Probados, este Tribunal tuvo como demostrado que Chile, a partir del retorno a la democracia, ha llevado adelante una política de reparaciones por las violaciones perpetradas durante el período de dictadura militar. Esta política ha beneficiado a las víctimas sobrevivientes y a los familiares de las víctimas fallecidas o desaparecidas, y ha buscado la reconciliación nacional. La Corte celebra los pasos dados por el Estado y resalta el trabajo de la Comisión Nacional de Verdad y Reconciliación, de la Corporación Nacional de Reparación y Reconciliación y de la Comisión Nacional sobre Prisión Política y Tortura (supra párr. 82.26 a 82.30). Asimismo, es un hecho no controvertido que los familiares del señor Almonacid Arellano se beneficiaron de esta política de reparación estatal (supra párr. 82.34 y 82.35).

139. Sin embargo, el presente caso se refiere a la denegación de justicia que sufrieron la señora Gómez Olivares y sus hijos a raíz de los hechos analizados en el capítulo anterior. Por tanto, esta Corte, de conformidad con los elementos probatorios recogidos durante el proceso y a la luz de los anteriores criterios, procede a analizar las pretensiones presentadas por la Comisión y por el representante y las consideraciones del Estado, para después dictar las reparaciones que crea pertinentes.

140. Alegatos de la Comisión

a) a efectos de reparar las violaciones cometidas en el presente caso, la Corte debe ordenar al Estado que:

i) realice una investigación completa, imparcial y efectiva de los hechos, con el objeto de establecer la verdad y sancionar a los responsables materiales e intelectuales del homicidio del señor Almonacid Arellano;

ii) adopte las medidas legislativas y de otra índole, de conformidad con sus procesos constitucionales y las disposiciones de la Convención Americana,

\footnotetext{
157 Cfr. Caso Montero Aranguren y otros, supra nota 155, párr. 117; Caso Ximenes Lopes, supra nota 14, párr. 209; y Caso de las Masacres de Ituango, supra nota 14, párr. 347.

158 Cfr. Caso Montero Aranguren y otros, supra nota 155, párr. 118; Caso Ximenes Lopes, supra nota 14, párr. 210; y Caso de las Masacres de Ituango, supra nota 14, párr. 348.
} 
con el propósito de suspender en forma definitiva y en todas las instancias, los efectos del Decreto Ley No. 2.191, y retrotraer los procesos judiciales en que haya sido aplicado al estado anterior a tal aplicación;

iii) garantice a las víctimas de violaciones a los derechos humanos cometidas durante la dictadura militar que gobernó el país entre septiembre 1973 y marzo de 1990, no ser sustraídas de la protección judicial y del ejercicio del derecho a un recurso sencillo y eficaz, en los términos de los artículos 8 y 25 de la Convención;

iv) adopte las medidas necesarias para garantizar que los casos relativos a violaciones a los derechos humanos no serán investigados o juzgados por el fuero militar, bajo ninguna circunstancia, y

v) otorgue una plena y adecuada reparación a los familiares del señor Almonacid Arellano, que comprenda cualquier indemnización adicional a las que ya hubiere recibido la familia y que se estime pertinente por daños materiales y morales; así como las costas y gastos legales incurridos por las víctimas en tramitación del caso tanto a nivel nacional, como las que se originen en la tramitación del presente caso ante el sistema interamericano.

b) además de la medida de satisfacción consistente en la investigación y sanción a los responsables de la muerte del señor Almonacid Arellano, el Tribunal debe ordenar que el Estado que:

i) en consulta con los familiares de la víctima, lleve a cabo un reconocimiento de la impunidad que ha imperado en este caso y de los obstáculos mantenidos durante años para la realización de la justicia, que incluya una disculpa pública, digna y significativa;

ii) haga público el resultado del proceso interno de investigación y sanción, con el fin de coadyuvar al derecho a la verdad de la familia Almonacid y de la sociedad chilena en su conjunto, y

iii) adopte medidas destinadas a la divulgación con fines didácticos de la decisión que dicte la Corte.

\section{Alegatos del representante}

a) "no es interés de los familiares del señor Almonacid Arellano obtener beneficios pecuniarios". Su interés radica en la consecución de justicia. "La reparación debe ser preventiva y la prevención importa el castigo a los culpables y el conocimiento de la verdad, pero también importa el pago pecuniario de los daños que se han provocado a las víctimas. Para [los familiares de las víctimas] ese es el tema menos importante [,] es más, [...] si el Estado de Chile asume y se allana a la demanda presentada por la Comisión Interamericana de Derechos Humanos renuncia[n] desde ya a cualquier indemnización, porque lo que [les] interesa es verdad y justicia y evidentemente sanción de los culpables";

b) reconoce que la señora Gómez Olivares desde el mes de marzo de 1992 está recibiendo una pensión que empezó aproximadamente con \$56.000,00 (cincuenta y seis mil pesos chilenos) y que actualmente asciende a $\$ 347.321,00$ (trescientos cuarenta y siete mil trescientos veintiún pesos chilenos) mensuales. También que los hijos del señor Almonacid Arellano, los señores Alfredo, Alexis y José Luis Almonacid Gómez, recibieron por una sola vez, a principios de 2005, un pago de $\$ 10.000 .000$ (diez millones de pesos 
chilenos) cada uno. También es efectivo que el menor de los hijos, José Luis, estudió con beca del Estado;

c) las sumas indicadas y la beca recibida resultan del homicidio del señor Almonacid Arellano, pero no es la reparación que emana de la presente acción internacional, es decir, la que deriva de la denegación de justicia, toda vez que importa un daño moral por el "incuantificable" esfuerzo de 23 años en búsqueda de justicia;

d) en cuanto al lucro cesante, el señor Almonacid Arellano en la actualidad estaría percibiendo en su condición de profesor un sueldo aproximado a los $\$ 450.000,00$ (cuatrocientos cincuenta mil pesos chilenos) mensuales. Falleció a los 42 años de edad y pudo haberse jubilado a los 65 años, de manera que al momento de su muerte le quedaban 33 años de vida activa, y

e) no hay que olvidar que al presenciar el homicidio de su marido, la señora Gómez Olivares se encontraba embarazada de ocho meses y medio de gestación y producto de ello, se le produjo un desprendimiento de placenta con la muerte inmediata del feto.

\section{Alegatos del Estado}

a) el avance jurisprudencial de los tribunales de justicia chilenos evoluciona en el sentido de declarar inaplicable el Decreto Ley de amnistía en casos de graves violaciones a los derechos humanos. Además, a la fecha de la audiencia en el presente caso se habían presentado cinco proyectos de ley tendientes a modificar el Decreto Ley No. 2.191;

b) en el informe Rettig se nombra individualmente a las víctimas, incluido el señor Almonacid Arellano, y luego de emitido ese informe se otorgó a todos los familiares de las víctimas reconocidas una reparación, consistente en un bono de reparación y una pensión vitalicia, además de bonos de reparación para los hijos, becas educacionales y atención gratuita a través del Programa de Salud dependiente del Ministerio de Salud (PRAIS);

c) la señora Gómez Olivares ha señalado que la reparación que ha recibido y que recibirá le es suficiente y que lo que busca es justicia, en consecuencia, la petición de reparación adicional planteada sin debe ser rechazada por improcedente.

Consideraciones de la Corte

\section{A) Beneficiarios}

143. En los términos del artículo 63.1 de la Convención Americana, la Corte considera como "parte lesionada" a la señora Elvira del Rosario Gómez Olivares y a los señores Alfredo, Alexis y José Luis Almonacid Gómez, en su carácter de víctimas de las violaciones detalladas en el capítulo anterior de la presente Sentencia.

144. Ahora, la Corte procede a determinar las medidas de reparación que estime oportunas para el presente caso. Para ello, primero se referirá a aquellas medidas que más se acerquen a la restitutio in integrum de las violaciones declaradas en esta Sentencia, a saber: la adecuación del derecho interno a la Convención Americana y la 
obligación del Estado de continuar con las investigaciones del presente caso, identificar, juzgar y sancionar a los responsables; medidas que además forman parte de las garantías de no repetición de hechos lesivos a los derechos humanos. En segundo lugar, la Corte se referirá a la compensación económica por los daños materiales e inmateriales que la Comisión y los representantes alegan que los beneficiarios sufrieron a consecuencia de los hechos del presente caso. Finalmente, la Corte ordenará la publicación de esta Sentencia como una medida de reparación del daño inmaterial.

B) Adecuación del derecho interno a la Convención Americana y obligación del Estado de continuar con las investigaciones del presente caso, identificar, juzgar y, en su caso, sancionar a los responsables

145. Como fue detallado en el párrafo 119 de la presente Sentencia, la Corte dispone que, al pretender amnistiar a los responsables de delitos de lesa humanidad, el Decreto Ley No. 2.191 es incompatible con la Convención Americana y, por tanto, carece de efectos jurídicos; en consecuencia, el Estado debe: i) asegurar que no siga representando un obstáculo para la investigación de la ejecución extrajudicial del señor Almonacid Arellano y para la identificación y, en su caso, sanción de los responsables, y ii) asegurar que el Decreto Ley No. 2.191 no siga representando un obstáculo para la investigación, juzgamiento y, en su caso, sanción de los responsables de otras violaciones similares acontecidas en Chile.

146. El Tribunal ha establecido que el Estado violó los derechos contenidos en los artículos 8 y 25 de la Convención Americana, en relación con el artículo 1.1 de la misma, en perjuicio de la señora Elvira del Rosario Gómez Olivares y los señores Alfredo, Alexis y José Luis Almonacid Gómez. Esta violación se produjo por dos causas: i) el otorgamiento de competencia a la jurisdicción militar para que conociera el caso por la muerte del señor Almonacid Arellano, y ii) por la aplicación del Decreto Ley No. 2.191. La primera violación fue producto de la resolución de la Corte Suprema de 5 de diciembre de 1996 (supra párr. 82.17), mientras que la segunda fue consecuencia de las sentencias de 28 de enero de 1997 del Segundo Juzgado Militar de Santiago (supra párr. 82.20) y de 25 de marzo de 1998 de la Corte Marcial (supra párr. 82.21).

147. En vista de lo anterior, este Tribunal dispone que el Estado debe dejar sin efecto las citadas resoluciones y sentencias emitidas en el orden interno, y remitir el expediente a la justicia ordinaria, para que dentro de un procedimiento penal se identifique y sancione a todos los responsables de la muerte del señor Almonacid Arellano.

148. La Corte ha establecido con anterioridad que el derecho a la verdad se encuentra subsumido en el derecho de la víctima o sus familiares a obtener de los órganos competentes del Estado el esclarecimiento de los hechos violatorios y las responsabilidades correspondientes, a través de la investigación y el juzgamiento que previenen los artículos 8 y 25 de la Convención ${ }^{159}$.

159 Cfr. Caso Barrios Altos, supra nota 140, párr. 48. Caso Bámaca Vélasquez. Sentencia de 25 de noviembre de 2000. Serie C No. 70, párr. 201. 
149. La Corte desea resaltar una vez más la importancia que han cumplido las diversas Comisiones chilenas (supra párr. 82.26 a 82.30) en tratar de construir de manera colectiva la verdad de lo ocurrido entre 1973 y 1990. Asimismo, la Corte valora que en el Informe de la Comisión Nacional de Verdad y Reconciliación se encuentra mencionado el nombre del señor Almonacid Arellano y se haga un breve resumen de las circunstancias de su ejecución.

150. No obstante, sin desconocer lo anterior, la Corte considera pertinente precisar que la "verdad histórica" contenida en los informes de las citadas Comisiones no puede sustituir la obligación del Estado de lograr la verdad a través de los procesos judiciales. En tal sentido, los artículos 1.1, 8 y 25 de la Convención protegen la verdad en su conjunto, por lo que Chile tiene el deber de investigar judicialmente los hechos referentes a la muerte del señor Almonacid Arellano, atribuir responsabilidades y sancionar a todos quienes resulten partícipes. En el propio informe de la Comisión Nacional de Verdad y Reconciliación se concluyó lo siguiente:

\begin{abstract}
Desde el punto de vista estrictamente preventivo, esta Comisión estima que un elemento indispensable para obtener la reconciliación nacional y evitar así la repetición de los hechos acaecidos, sería el ejercicio completo, por parte del Estado, de sus facultades punitivas. Una cabal protección de los derechos humanos sólo es concebible en un real estado de Derecho. Y un Estado de Derecho supone el sometimiento de todos los ciudadanos a la ley y a los tribunales de justicia, lo que envuelve la aplicación de sanciones previstas en la legislación penal, igual para todos, a los transgresores de las normas que cautelan el respeto a los derechos humanos ${ }^{160}$.
\end{abstract}

151. El Estado no podrá argüir ninguna ley ni disposición de derecho interno para eximirse de la orden de la Corte de investigar y sancionar penalmente a los responsables de la muerte del señor Almonacid Arellano. Chile no podrá volver a aplicar el Decreto Ley No. 2.191, por todas las consideraciones dadas en la presente Sentencia, en especial las contenidas en el párrafo 145. Pero además, el Estado no podrá argumentar prescripción, irretroactividad de la ley penal, ni el principio ne bis in idem, así como cualquier excluyente similar de responsabilidad, para excusarse de su deber de investigar y sancionar a los responsables.

152. En efecto, por constituir un crimen de lesa humanidad, el delito cometido en contra del señor Almonacid Arellano, además de ser inamnistiable, es imprescriptible. Como se señaló en los párrafos 105 y 106 de esta Sentencia, los crímenes de lesa humanidad van más allá de lo tolerable por la comunidad internacional y ofenden a la humanidad toda. El daño que tales crímenes ocasionan permanece vigente para la sociedad nacional y para la comunidad internacional, las que exigen la investigación y el castigo de los responsables. En este sentido, la Convención sobre la imprescriptibilidad de los crímenes de guerra y de los crímenes de lesa humanidad ${ }^{161}$ claramente afirmó que tales ilícitos internacionales "son imprescriptibles, cualquiera que sea la fecha en que se hayan cometido".

153. Aún cuando Chile no ha ratificado dicha Convención, esta Corte considera que la imprescriptibilidad de los crímenes de lesa humanidad surge como categoría de norma de Derecho Internacional General (ius cogens), que no nace con tal Convención sino

\footnotetext{
160 Cfr. Informe de la Comisión Nacional de Verdad y Reconciliación (expediente de anexos a los alegatos finales escritos del Estado, Anexo 2, f. 2520).

161 Adoptada por la Asamblea General de las Naciones Unidas en su Resolución 2391 (XXIII) de 26 de noviembre de 1968. Entró en vigor el 11 de noviembre de 1970.
} 
que está reconocida en ella. Consecuentemente, Chile no puede dejar de cumplir esta norma imperativa.

154. En lo que toca al principio ne bis in idem, aún cuando es un derecho humano reconocido en el artículo 8.4 de la Convención Americana, no es un derecho absoluto y, por tanto, no resulta aplicable cuando: i) la actuación del tribunal que conoció el caso y decidió sobreseer o absolver al responsable de una violación a los derechos humanos o al derecho internacional obedeció al propósito de sustraer al acusado de su responsabilidad penal; ii) el procedimiento no fue instruido independiente o imparcialmente de conformidad con las debidas garantías procesales, o iii) no hubo la intención real de someter al responsable a la acción de la justicia ${ }^{162}$. Una sentencia pronunciada en las circunstancias indicadas produce una cosa juzgada "aparente" o "fraudulenta"163. Por otro lado, esta Corte considera que si aparecen nuevos hechos o pruebas que puedan permitir la determinación de los responsables de violaciones a los derechos humanos, y más aún, de los responsables de crímenes de lesa humanidad, pueden ser reabiertas las investigaciones, incluso si existe un sentencia absolutoria en calidad de cosa juzgada, puesto que las exigencias de la justicia, los derechos de las víctimas y la letra y espíritu de la Convención Americana desplaza la protección del ne bis in idem.

155. En el presente caso, se cumplen dos de los supuestos señalados. En primer lugar, la causa fue llevada por tribunales que no guardaban la garantía de competencia, independencia e imparcialidad. En segundo lugar, la aplicación del Decreto Ley No. 2.191 consistió en sustraer a los presuntos responsables de la acción de la justicia y dejar el crimen cometido en contra del señor Almonacid Arellano en la impunidad. En consecuencia, el Estado no puede auxiliarse en el principio de ne bis in idem, para no cumplir con lo ordenado por la Corte (supra párr. 147).

156. Por otro lado, el Estado, para cumplir con su deber investigativo, debe garantizar que todas las instituciones públicas brinden las facilidades necesarias al tribunal ordinario que conocerá el caso del señor Almonacid Arellano (supra párr. 147) y, en consecuencia, deberán remitirle la información y documentación que les solicite, llevar a su presencia a las personas que éste requiera y realizar las diligencias que les ordene.

157. Finalmente, el Estado debe asegurar que la señora Elvira del Rosario Gómez Olivares y los señores Alfredo, Alexis y José Luis Almonacid Gómez tengan pleno acceso y capacidad de actuar en todas las etapas e instancias de dichas investigaciones, de acuerdo con la ley interna y las normas de la Convención Americana $^{164}$. Los resultados de las investigaciones deberán ser públicamente

162 Cfr. Cfr. O.N.U., Estatuto de Roma de la Corte Penal Internacional, aprobado por la Conferencia Diplomática de Plenipotenciarios de las Naciones Unidas sobre el establecimiento de una corte penal internacional, U.N. Doc. A/CONF.183/9, 17 de julio de 1998, art. 20; Estatuto del Tribunal Penal Internacional para la ex Yugoslavia, S/Res/827, 1993, Art. 10, y Estatuto del Tribunal Penal Internacional para Ruanda, S/Res/955, 8 de noviembre de 1994, Art. 9.

163 Cfr. Caso Carpio Nicolle y otros. Sentencia de 22 de noviembre de 2004. Serie C No. 117, párr. 131.

164 Cfr. Caso Montero Aranguren y otros, supra nota 155, párr. 139; Caso Baldeón García, supra nota 14, párr. 199; y Caso de Blanco Romero y otros. Sentencia de 28 de noviembre de 2005. Serie C No. 138, párr. 97. 
divulgados por el Estado, de manera tal que la sociedad chilena pueda conocer la verdad acerca de los hechos del presente caso ${ }^{165}$.

\section{C) Daño material e inmaterial}

158. El daño material supone la pérdida o detrimento de los ingresos, los gastos efectuados con motivo de los hechos y las consecuencias de carácter pecuniario que tengan un nexo causal con las violaciones ${ }^{166}$. El daño inmaterial puede comprender tanto los sufrimientos y las aflicciones causados a las víctimas de violaciones de derechos humanos y a sus allegados, como el menoscabo de valores muy significativos para las personas o sus condiciones de existencia ${ }^{167}$.

159. En el presente caso, el representante fundamenta su solicitud de indemnización por daño material e inmaterial en la muerte del señor Almonacid Arellano. Así, por ejemplo, se refiere a las bonificaciones que recibió su familia como indemnización a partir del año 1992, la expectativa de vida del señor Almonacid Arellano y el lucro cesante, y el dolor de los familiares por la pérdida de su ser querido en las circunstancias violentas en que se dieron los hechos. Asimismo, la Comisión solicita que se otorgue una "indemnización adicional a las que ya hubiere recibido la familia y que se estime pertinente por daños materiales y morales". Es decir, que la Corte incremente el monto que la familia del señor Almonacid Arellano ha recibido como indemnización por la muerte de éste.

160. Las violaciones declaradas en esta Sentencia se refieren a la denegación de justicia que sufrieron los familiares del señor Almonacid Arellano y el incumplimiento del Estado de sus deberes generales consagrados en los artículos 1.1 y 2 de la Convención Americana. Consecuentemente, las reparaciones que se dictan en esta instancia deben referirse únicamente a estos aspectos y no a aquellos sobre los cuales la Corte no se ha pronunciado por falta de competencia ratione temporis. Ni el representante ni la Comisión han presentado argumentos ni pruebas que demuestren que las violaciones declaradas en la presente Sentencia produjeron un daño material. En vista de ello, la Corte no fijará indemnización por este concepto.

161. En lo referente al daño inmaterial, este Tribunal reconoce que las víctimas del presente caso sufrieron por la denegación de justicia producto de los hechos que se analizaron en los capítulos anteriores. De igual forma, toma nota lo expresado por el representante en el sentido de que el interés principal de las víctimas en este caso es la consecución de justicia. Por otro lado, la Corte valora positivamente la política de reparación de violaciones a derechos humanos adelantada por el Estado (supra párr. 82.26 a 82.33), dentro de la cual la señora Gómez Olivares y sus hijos recibieron aproximadamente la cantidad de US\$98.000,00 (noventa y ocho mil dólares de los Estados Unidos de América), más beneficios educacionales correspondientes aproximadamente a US\$12.180,00 (doce mil ciento ochenta dólares de los Estados Unidos de América). Teniendo en cuenta todo lo anterior, el Tribunal considera no ordenar el pago de una compensación económica por concepto de daño inmaterial,

165 Cfr. Caso Montero Aranguren y otros, supra nota 155, párr. 139; Caso Baldeón García, supra nota 14, párr. 199; y Caso de la Masacre de Pueblo Bello, supra nota 138, párr. 267.

166 Cfr. Caso Ximenes Lopes, supra nota 14, párr. 220; Caso Baldeón García, supra nota 14, párr. 183; y Caso Comunidad indígena Sawhoyamaxa. Sentencia de 29 de marzo de 2006. Serie C No. 146, párr. 216.

167 Cfr. Caso Montero Aranguren y otros, supra nota 155, párr. 130; Caso de las Masacres de Ituango, supra nota 14, párr. 383; y Caso Baldeón García, supra nota 14, párr. 188. 
debido a que estima, como lo ha hecho en otros casos, que esta sentencia constituye per se una forma de reparación ${ }^{168}$, y que las medidas que se detallan en los párrafos 145 a 157 de esta Sentencia constituyen una debida reparación en los términos del artículo 63.1 de la Convención Americana.

162. Como lo ha ordenado en otras oportunidades ${ }^{169}$, la Corte estima que, como medida de satisfacción, el Estado deberá publicar en el Diario Oficial y en otro diario de amplia circulación nacional, por una sola vez y sin las notas al pié de página, el capítulo relativo a los hechos probados de esta Sentencia y la parte resolutiva de la misma. Para estas publicaciones se fija el plazo de seis meses, a partir de la notificación de la presente Sentencia.

\section{E) Costas y Gastos}

163. Las costas y gastos están comprendidos dentro del concepto de reparación consagrado en el artículo 63.1 de la Convención Americana, puesto que la actividad desplegada por las víctimas con el fin de obtener justicia, tanto a nivel nacional como internacional, implica erogaciones que deben ser compensadas cuando la responsabilidad internacional del Estado es declarada mediante una sentencia condenatoria. En cuanto a su reembolso, corresponde al Tribunal apreciar prudentemente su alcance. Teniendo en cuenta la naturaleza de la jurisdicción internacional de la protección de los derechos humanos, esta apreciación puede ser realizada con base en el principio de equidad y tomando en cuenta los gastos señalados por las partes, siempre que su quantum sea razonable ${ }^{170}$.

164. En el presente caso, la Corte nota que el representante no ha acreditado ni probado un monto concreto por concepto de costas y gastos, por lo que procederá a fijarlas en equidad. Para ello, el Tribunal considera que las costas y gastos a nivel interno deben calcularse desde el 5 de diciembre de 1996, fecha en que la Corte Suprema resolvió que la jurisdicción militar era la competente para seguir conociendo el caso (supra párr. 82.17), puesto que desde esa fecha se inició la denegación de justicia que se ha analizado en el presente caso. Las costas y gastos a nivel internacional se considerarán desde la presentación de la denuncia ante la Comisión Interamericana. En consecuencia, la Corte estima equitativo ordenar al Estado que reintegre la cantidad de US\$10.000,00 (diez mil dólares de los Estados Unidos de América) o su equivalente en moneda chilena, a la señora Elvira del Rosario Gómez Olivares, quien entregará a su representante la cantidad que le corresponda, por concepto de costas y gastos.

\section{$\mathbf{X}$ \\ MODALI DAD DE CUMPLI MI ENTO}

\footnotetext{
168 Cfr. Caso Montero Aranguren y otros, supra nota 155, párr. 131; Caso Ximenes Lopes, supra nota 14, párr. 236; y Caso de las Masacres de Ituango, supra nota 14, párr. 387.

169 Cfr. Caso Montero Aranguren y otros, supra nota 155, párr. 151; Caso Ximenes Lopes, supra nota 14, párr. 249; y Caso de las Masacres de Ituango, supra nota 14, párr. 410.

170 Cfr. Caso Montero Aranguren y otros, supra nota 155, párr. 152; Caso de las Masacres de Ituango, supra nota 14, párr. 414; y Caso Baldeón García, supra nota 14, párr. 208.
} 
165. Para dar cumplimiento a la presente Sentencia, el Estado deberá efectuar el reintegro de costas y gastos dentro del plazo de un año contado a partir de la notificación de la presente Sentencia. En cuanto a la publicación de la presente Sentencia (supra párr. 162), el Estado dispone de un plazo de seis meses, contado a partir de la notificación de la misma, para cumplir con lo ordenado. En el caso de las otras reparaciones ordenadas, deberá cumplirlas en un plazo razonable (supra párrs. 145 a 157).

166. Si por causas atribuibles a la beneficiaria del reintegro de costas y gastos no fuese posible que ésta lo reciba dentro del plazo indicado en el párrafo anterior, el Estado consignará dicho monto a favor de la beneficiaria en una cuenta o certificado de depósito en una institución financiera chilena solvente, en dólares estadounidenses y en las condiciones financieras más favorables que permitan la legislación y la práctica bancaria. Si al cabo de diez años la indemnización no ha sido reclamada, las cantidades serán devueltas al Estado con los intereses devengados.

167. El Estado puede cumplir sus obligaciones mediante el pago en dólares de los Estados Unidos de América o en una cantidad equivalente en moneda chilena, utilizando para el cálculo respectivo el tipo de cambio entre ambas monedas que esté vigente en la plaza de Nueva York, Estados Unidos de América, el día anterior al pago.

168. La cantidad asignada en la presente Sentencia bajo el concepto de reintegro de costas y gastos, no podrá ser afectada o condicionada por motivos fiscales actuales o futuros. Por ende, deberán ser entregada a los beneficiaria en forma íntegra conforme a lo establecido en esta Sentencia.

169. En caso de que el Estado incurriera en mora, deberá pagar un interés sobre la cantidad adeudada, correspondiente al interés bancario moratorio en Chile.

170. Conforme a su práctica constante, la Corte se reserva la facultad inherente a sus atribuciones y derivada, asimismo, del artículo 65 de la Convención Americana, de supervisar el cumplimiento íntegro de la presente Sentencia. El caso se dará por concluido una vez que el Estado haya dado cabal cumplimiento a lo dispuesto en el presente Fallo. Dentro del plazo de un año, contado a partir de la notificación de esta Sentencia, Chile deberá rendir a la Corte un informe sobre las medidas adoptadas para dar cumplimiento a la misma.

\section{XI \\ Puntos Resolutivos}

171. Por tanto,

\section{LA CORTE,}

\section{DECIDE:}

Por unanimidad:

1. Desestimar las excepciones preliminares interpuestas por el Estado.

\section{DeCLARA:}

Por unanimidad, que: 
2. El Estado incumplió sus obligaciones derivadas de los artículos 1.1 y 2 de la Convención Americana sobre Derechos Humanos, y violó los derechos consagrados en los artículos 8.1 y 25 de dicho tratado, en perjuicio de la señora Elvira del Rosario Gómez Olivares y de los señores Alfredo, Alexis y José Luis Almonacid Gómez, en los términos de los párrafos 86 a 133 de la presente Sentencia.

3. Al pretender amnistiar a los responsables de delitos de lesa humanidad, el Decreto Ley No. 2.191 es incompatible con la Convención Americana y, por tanto, carece de efectos jurídicos, a la luz de dicho tratado.

4. Esta Sentencia constituye per se una forma de reparación.

\section{Y DISPONE:}

Por unanimidad, que:

5. El Estado debe asegurarse que el Decreto Ley No. 2.191 no siga representando un obstáculo para la continuación de las investigaciones de la ejecución extrajudicial del señor Almonacid Arellano y para la identificación y, en su caso, el castigo de los responsables, conforme a lo señalado en los párrafos 145 a 157 de esta Sentencia.

6. El Estado debe asegurarse que el Decreto Ley No. 2.191 no siga representando un obstáculo para la investigación, juzgamiento y, en su caso, sanción de los responsables de otras violaciones similares acontecidas en Chile, conforme a lo señalado en el párrafo 145 de esta Sentencia.

7. El Estado deberá efectuar el reintegro de las costas y gastos dentro del plazo de un año, contado a partir de la notificación del presente fallo, en los términos de los párrafos 164 de esta Sentencia.

8. El Estado deberá realizar las publicaciones señaladas en el párrafo 162 de la presente Sentencia, dentro del plazo de seis meses contados a partir de la notificación de la misma.

9. Supervisará el cumplimiento íntegro de esta Sentencia, y dará por concluido el presente caso una vez que el Estado haya dado cabal cumplimiento a lo dispuesto en la misma. Dentro del plazo de un año, contado a partir de la notificación de esta Sentencia, el Estado deberá rendir a la Corte un informe sobre las medidas adoptadas para darle cumplimiento.

El Juez Antônio A. Cançado Trindade hizo conocer a la Corte su Voto Razonado, el cual acompaña la presente Sentencia.

Redactada en español y en inglés, haciendo fe el texto en español, en San José, Costa Rica, el día 26 de septiembre de 2006.

Sergio García Ramírez

Presidente 


\section{Pablo Saavedra Alessandri Secretario}

Comuníquese y ejecútese,

Sergio García Ramírez Presidente

Pablo Saavedra Alessandri Secretario 


\title{
VOTO RAZONADO DEL J UEZ A.A. CANÇADO TRI NDADE
}

1. He votado en favor de la adopción, por la Corte Interamericana de Derechos Humanos, de la presente Sentencia en el caso Almonacid Arellano y Otros versus Chile. Dada la importancia de las cuestiones en ella tratadas por la Corte, me veo en la obligación de agregar a la presente Sentencia este Voto Razonado, con mis reflexiones personales como fundamento de mi posición al respecto de lo deliberado por el Tribunal Corte. Centraré mis reflexiones en tres puntos básicos, a saber: a) la falta de validez jurídica de las autoamnistías; b) las autoamnistías y la obstrucción y denegación de justicia: la ampliación del contenido material de las prohibiciones del jus cogens; y c) la conceptualización de los crímenes contra la humanidad en la confluencia entre el Derecho Internacional de los Derechos Humanos y Derecho Penal Internacional.

\section{La Falta de Validez J urídica de las Autoamnistías.}

2. La presente Sentencia de la Corte Interamericana en el caso Almonacid Arellano y Otros se inserta en su línea de razonamiento inaugurada en su histórica Sentencia (del 14.03.2001) en el caso Barrios Altos referente al Perú, en la cual la Corte afirmó que

\begin{abstract}
"son inadmisibles las disposiciones de amnistía, las disposiciones de prescripción y el establecimiento de excluyentes de responsabilidad que pretendan impedir la investigación y sanción de los responsables de las violaciones graves de los derechos humanos tales como la tortura, las ejecuciones sumarias, extralegales o arbitrarias y las desapariciones forzadas, todas ellas prohibidas por contravenir derechos inderogables reconocidos por el Derecho Internacional de los Derechos Humanos" (párr. 41).
\end{abstract}

La Sentencia de esta Corte en el caso de Barrios Altos, - en el cual hubo allanamiento por parte del Estado peruano, - se ha tornado mundialmente conocida y reconocida en los círculos jusinternacionales, por haber sido la primera vez que un tribunal internacional determinó que una ley de autoamnistía carece de efectos jurídicos. En su Sentencia en el caso de Barrios Altos, la Corte afirmó, de forma pionera y lapidaria, que

"Como consecuencia de la manifiesta incompatibilidad entre las leyes de autoamnistía y la Convención Americana sobre Derechos Humanos, las mencionadas leyes carecen de efectos jurídicos y no pueden seguir representando un obstáculo para la investigación de los hechos (...) ni para la identificación y el castigo de los responsables (...)" (párr 44).

3. En el presente caso Almonacid Arellano y Otros, si bien no hubo allanamiento por parte del Estado chileno, éste ha asumido una actitud positiva y constructiva en el procedimiento ante la Corte (como se desprende de la presente Sentencia), pues en ningún momento ha afirmado que el Decreto Ley n. 2191 (de auto-amnistía) del 18.04.1978 no viola la Convención Americana (párr. 90), y él propio ha admitido que "en principio, las leyes de amnistía o autoamnistía son contrarias a las normas del Derecho Internacional de los Derechos Humanos" (párr. 112). En la presente Sentencia, la Corte correctamente caracterizó el referido Decreto Ley No. 2191 como de autoamnistía, dictado por "el propio régimen militar, para sustraer de la acción de la justicia principalmente sus propios crímenes", perpetrados durante el estado de sitio entre 11.09.1973 y 10.03.1978 (párrs. 119 y 81.10). 
4. Es de conocimiento general que hay distintos tipos de amnistía 1, "concedida" en medio a pretextos de alcanzar la "reconciliación nacional" mediante la revelación de la "verdad" (según los términos de la amnistía en cuestión) y el perdón; esos pretextos, en la práctica de algunos Estados, han sido invocados individual o conjuntamente ${ }^{2}$. Sin embargo, el perdón no puede ser impuesto por decreto ley, ni de ninguna otra forma: sólo puede ser concedido espontáneamente por las propias víctimas. Y, para eso, éstas han buscado la realización de la justicia. A propósito, la Corte recuerda en la presente Sentencia que, al dar a público, en 04.03.1991 en Informe final (del 08.02.1991) de la Comisión de la Verdad, el entonces Presidente de Chile, Sr. Patricio Aylwin, pidió perdón, en nombre del Estado (y de la nación), a los familiares de las víctimas, en los siguientes términos:

"Cuando fueron agentes del Estado los que ocasionaron tanto sufrimiento, y los órganos competentes del Estado no pudieron o no supieron evitarlo o sancionarlo, y tampoco hubo la necesaria reacción social para impedirlo, son el Estado y la sociedad entera los responsables, bien sea por acción o por omisión. Es la sociedad chilena la que está en deuda con las víctimas de las violaciones a los derechos humanos. (...) Por eso es que yo me atrevo, en mi calidad de Presidente de la República, a asumir la representación de la Nación entera para, en su nombre, pedir perdón a los familiares de las víctimas"

5. Los diferentes tipos de amnistía han sido estudiados en los últimos años, sin que sea necesario retomar aquí este aspecto de la materia en aprecio. Cabe, esto sí, en las circunstancias del cas d'espèce, retener la atención sobre un tipo específico de amnistía, la llamada "autoamnistía", que busca substraer de la justicia los responsables por violaciones graves de los derechos humanos, conllevando así a la impunidad. Cabe, de inicio, recordar que las verdaderas leyes no pueden ser arbitrarias, no tienen nombre y apellido de los que se consideran estar por encima de ellas. Cuentan con un cierto grado de abstracción, inevitable en la operación del Derecho. Encierran principios, que las informan y las conforman, y les dan vida propia, siendo aprehendidos por la razón humana, la recta ratio. Dan expresión a valores, que se muestran siempre presentes. Como se señaló en un célebre estudio sobre la interpretación de las leyes,

"Las leyes permanecen idénticas a sí mismas, mientras por debajo de ellas fluye el curso siempre nuevo de la historia y de la vida"4.

1. Cf., v.g., L. Joinet (rapporteur), Estudio sobre las Leyes de Amnistía, documento E/CN.4/Sub.2/1985/16/Rev.1, Ginebra, ONU/Subcomisión de Prevención de Discriminaciones y Protección de Minorías, 1985, pp. 1-22; J. Gavron, "Amnesties in the Light of Developments in International Law and the Establishment of the International Criminal Court", 51 International and Comparative Law Quarterly (2002) pp. 91-117.

2. A. O'Shea, Amnesty for Crime in International Law and Practice, The Hague, Kluwer, 2004, p. 23, y cf. pp. 25-33.

${ }^{3}$. Cit. in párrafo 81.26 de esta Sentencia. Y cf., al respecto, P. Aylwin Azocar, "La Comisión de la Verdad y Reconciliación de Chile", in Estudios Básicos de Derechos Humanos, tomo II (eds. A.A. Cançado Trindade y L. González Volio), San José de Costa Rica, IIDH, 1995, pp. 105-119.

4. S. Soler, La Interpretación de la Ley, Barcelona, Ed. Ariel, 1962, p. 108, y cf. pp. 15, 115, 117 y 143. 
6. Esta misma Corte, en su Opinión Consultiva n. 6 (del 09.05.1986), sostuvo que

"la palabra leyes en el artículo 30 de la Convención [Americana] significa norma jurídica de carácter general, ceñida al bien común, emanada de los órganos legislativos constitucionalmente previstos y democráticamente elegidos, y elaborada según el procedimiento establecido por las Constituciones de los Estados Partes para la formación de las leyes" (párr. 38).

7. Las autoamnistías están lejos de satisfacer todos estos requisitos. Las autoamnistías no son verdaderas leyes, por cuanto desprovistas del necesario carácter genérico de éstas ${ }^{5}$, de la idea del Derecho que las inspira (esencial inclusive para la seguridad jurídica) ${ }^{6}$, y de su búsqueda del bien común. Ni siquiera buscan la organización o reglamentación de las relaciones sociales para la realización del bien común. Todo lo que pretenden es substraer de la justicia determinados hechos, encubrir violaciones graves de derechos, y asegurar la impunidad de algunos. No satisfacen los mínimos requisitos de leyes, todo lo contrario, son aberraciones antijurídicas.

8. Quien escribió más elocuentemente sobre los fines del derecho y las injusticias practicadas con base en supuestas "leyes" fue, a mi juicio, Gustav Radbruch. En sus célebres Fünf Minuten Rechtsphilosophie, publicado por primera vez como una circular dirigida a los estudiantes de la Universidad de Heidelberg en 1945, poco después - y ciertamente bajo el impacto - de las atrocidades de la II guerra mundial, el gran jusfilósofo afirmó que "los tres valores que todo el derecho debe servir" son la justicia, el bien común y la seguridad jurídica. Sin embargo, hay "leyes" que se muestran tan nocivas para el bien común, tan injustas, que se muestran desproveídas del carácter de "jurídicas".

9. En su crítica devastadora al positivismo, G. Radbruch prosiguió: "También hay principios fundamentales del derecho que son más fuertes que todo y cualquier precepto jurídico positivo, de tal modo que toda ley que los viole no podrá dejar de ser privada de validez ${ }^{7}$. Y remató el gran jusfilósofo que la concepción positivista

"fue la que dejó sin defensa el pueblo y los juristas contra las leyes más arbitrarias, más crueles y más criminosas. Torna equivalentes, en última instancia, el derecho y la fuerza, llevando a creer que dónde esté la segunda estará también el primer" ${ }^{\prime 8}$.

10. Al evocar el pensamiento de G. Radbruch al final de su vida, me permito agregar que las autoamnistías son, a mi modo de ver, la propia negación del Derecho. Violan abiertamente principios generales del derecho, como el acceso a la justicia (que en mi concepción pertenece al dominio del jus cogens), la igualdad ante la ley, el derecho al juez natural, entre otros. En algunos casos, han encubierto inclusive crímenes contra la humanidad y actos de genocidio ${ }^{9}$.

5. G. Radbruch, Introdução à Ciência do Direito [originalmente Einführung in die Rechtswissenschaft], São Paulo, Livr. Martins Fontes Ed., 1999, p. 8.

${ }^{6}$. G. Radbruch, Filosofia do Direito, tomo I, Coimbra, A. Amado Ed., 1961, pp. 185-186.

7. G. Radbruch, Filosofia do Direito, tomo II, Coimbra, A. Amado Ed., 1961, pp. 213-214.

8. Ibid., pp. 211-214.

9. Por ejemplo, el tratado de Sevres (1920) prevía la incriminación de los turcos responsables por el 
En la medida en que impiden la realización de la justicia por crímenes de tamaña gravedad, las autoamnistías son violatorias del jus cogens (cf. infra).

11. En la presente Sentencia en el caso Almonacid Arellano y Otros, la Corte Interamericana, en la misma línea jurisprudencial inaugurada en el caso Barrios Altos, advirtió que las autoamnistías con las características del supracitado Decreto Ley n. 2191 de 1978,

"conducen a la indefensión de las víctimas y a la perpetuación de la impunidad de los crímenes de lesa humanidad, por lo que son manifiestamente incompatibles con la letra y el espíritu de la Convención Americana e indudablemente afectan derechos consagrados en ella. Ello constituye per se una violación de la Convención y genera responsabilidad internacional del Estado. En consecuencia, dada su naturaleza, el Decreto Ley n. 2191 carece de efectos jurídicos y no puede seguir representando un obstáculo para la investigación de los hechos que constituyen este caso, ni para la identificación y el castigo de los responsables, ni puede tener igual o similar impacto respecto de otros casos de violación de los derechos consagrados en la Convención Americana acontecidos en Chile" (párr. 118).

12. En nada sorprende que, en la bibliografía jurídica especializada, el referido Decreto Ley n. 2191 haya sido particularmente criticado ${ }^{10}$. Al fin y al cabo, fue precisamente en el período cubierto por dicha auto-amnistía que la mayor parte de los crímenes de Estado del régimen Pinochet fueron perpetrados. La Corte Interamericana ha establecido en la presente Sentencia que, precisamente en el período entre 11.09.1973 y 10.03.1978 la "dictadura militar" en Chile,

"dentro de una política de Estado encaminada a causar miedo, atacó masiva y sistemáticamente a sectores de la población civil considerados como opositora al régimen, mediante una serie de graves violaciones de los derechos humanos y del Derecho Internacional, entre las cuales se cuentan al menos 3.197 víctimas de ejecuciones sumarias y desapariciones forzadas, y 33.221 detenidos, de quienes una inmensa mayoría fue víctima de tortura" (párr. 102).

Entre estas numerosas víctimas estuvo el Sr. Almonacid Arellano, ejecutado extrajudicialmente por agentes estatales, en medio a un "patrón sistemático y generalizado" de crímenes contra la población civil (párr. 103).

13. Relatos y testimonios publicados en los últimos años coinciden al respecto: la dictadura instaurada en Chile el 11 de septiembre de 1973 optó por la "eliminación inmediata" mediante "fusilamientos colectivos"; del total de no menos de 3.197 muertos y desaparecidos, "1.823 lo fueron en los primeros cuatro meses después del golpe"11. El 11 de septiembre de 1973

masacre de los arménios, pero fue terminado por el tratado de Lausanne (1923) que "concedió" una amnistía para los perpetradores de aquel que vino a ser considerado el primer genocidio del siglo XX; cit. in A. O'Shea, op. cit. supra n. (2), p. 15; y cf. B. Bruneteau, Le siècle des génocides - Violences, massacres et processus génocidaires de l'Arménie au Rwanda, Paris, A. Colin, 2004, pp. 48-72.

10. Cf., inter alia, v.g., B. Chigara, Amnesty in International Law - The Legality under International Law of National Amnesty Laws, Harlow/London, Longman, 2002, pp. 11 y 114; A. O'Shea, Amnesty for Crime in International Law..., op. cit. supra n. (2), pp. 68, 285-286 y 313.

11. N.C. Mariano, Operación Cóndor - Terrorismo de Estado en el Cono Sur, Buenos Aires, Ed. LohléLumen, 1998, p. 87; y cf. A. Boccia Paz, M.H. López, A.V. Pecci y G. Giménez Guanes, En los Sótanos de los Generales - Los Documentos Ocultos del Operativo Cóndor, Asunción, Expolibro/Servilibro, 2002, p. 
empezaba así la "guerra [sic] contra el terrorismo", al igual que el 11 de septiembre de 2001: en una y otra se optó por violar los derechos humanos y el Derecho Internacional, al combatir el terrorismo equivocadamente mediante el terrorismo de Estado.

14. En la "guerra total" iniciada el 11 de septiembre de 1973, personas sospechosas y prisioneros políticos

"fueron amontonados en improvisados campos de concentración, como el Estadio Nacional de Santiago. Se ejecutó sumariamente a más de mil personas (...). Los militares chilenos iniciaron una nueva táctica para América Latina: enterraban los cuerpos de los prisioneros ejecutados en tumbas secretas masivas o 'fosas comunes', mientras negaban a las familias de los prisioneros que alguna vez hubieran estado bajo custodia.

(...) Porque el enemigo tenía alcance internacional, Pinochet ideó un esquema internacional para vencerlo. Con este fin creó una alianza secreta con los gobiernos militares de Uruguay, Paraguay, Bolivia, Brasil y Argentina. (...) La iniciativa fue bautizada como 'Operación Cóndor' (...). Casi invariablemente, las víctimas del Cóndor desaparecían"12.

15. Pretender amnistiar los responsables por la perpetración de dichos crímenes de Estado es una afrenta al Estado de Derecho en una sociedad democrática. Como sostuve en mi Voto Concurrente en el caso de Barrios Altos,

"Las llamadas autoamnistías son, en suma, una afrenta inadmisible al derecho a la verdad y al derecho a la justicia (empezando por el propio acceso a la justicia). Son ellas manifiestamente incompatibles con las obligaciones generales - indisociables - de los Estados Partes en la Convención Americana de respetar y garantizar los derechos humanos por ella protegidos, asegurando el libre y pleno ejercicio de los mismos (en los términos del artículo 1(1) de la Convención), así como de adecuar su derecho interno a la normativa internacional de protección (en los términos del artículo 2 de la Convención). Además, afectan los derechos protegidos por la Convención, en particular los derechos a las garantías judiciales (artículo 8) y a la protección judicial (artículo 25). (...)

Hay otro punto que me parece aún más grave en relación con la figura degenerada - un atentado en contra el propio Estado de Derecho - de las llamadas leyes de autoamnistía. Como los hechos del presente caso Barrios Altos lo revelan - al llevar la Corte a declarar, en los términos del reconocimiento de responsabilidad internacional efectuado por el Estado demandado, las violaciones de los derechos a la vida ${ }^{13}$ y a la integridad personal ${ }^{14}$, - dichas leyes afectan derechos inderogables - el minimum universalmente reconocido, - que recaen en el ámbito del jus cogens" (párrs. 5 y 10).

16. Y concluí mi referido Voto Concurrente ponderando que

187.

12. J. Dinges, Operación Cóndor - Una Década de Terrorismo Internacional en el Cono Sur, Santiago, Ediciones B Chile, 2004, pp. 22-23.

13. Artículo 4 de la Convención Americana.

14. Artículo 5 de la Convención Americana. 
"ningún Estado puede considerarse por encima del Derecho, cuyas normas tienen por destinatarios últimos los seres humanos. (..) Hay que decirlo y repetirlo con firmeza, cuantas veces sea necesario: en el dominio del Derecho Internacional de los Derechos Humanos, las llamadas 'leyes' de autoamnistía no son verdaderamente leyes: no son nada más que una aberración, una afrenta inadmisible a la conciencia jurídica de la humanidad" (párr. 26).

\section{Las Autoamnistías y la Obstrucción y Denegación de Justicia: La Ampliación del Contenido Material de las Prohibiciones del J us Cogens.}

17. Dichas autoamnistías, aunque basadas en instrumentos "legales", - leyes, decretos leyes, u otros, - son la propia negación del Derecho, son verdaderamente una aberración jurídica. La adopción y promulgación de dichas autoamnistías constituyen, a mi modo de ver, una violación adicional de la Convención Americana sobre Derechos Humanos. El tempus commisi delicti es el de la decretación de la autoamnistía en cuestión, - violación adicional de la Convención que se suma a las violaciones originales de la misma en el caso concreto. La autoamnistía viola per se, por su propia existencia, los artículos 1(1) y 2 de la Convención Americana, obstruye el acceso a la justicia por parte de los victimados o sus familiares (artículos 25 y 8 de la Convención), impide la investigación de los hechos (requerida por el artículo $1(1)$ ) de la Convención, imposibilita la realización de la justicia y el otorgamiento de reparaciones adecuadas. Conllevan, en suma, a las más flagrantes obstrucción y denegación de justicia, dejando los victimados y sus familiares en la más completa e inadmisible indefensión.

18. Tal denegación de justicia se configura circundada de circunstancias agravantes, con todas sus consecuencias jurídicas, por cuanto conlleva al deliberado encubrimiento de violaciones de derechos fundamentales, v.g., por medio de la práctica sistemática de detenciones ilegales o arbitrarias, secuestros, tortura y desapariciones forzadas de personas, cuya prohibición absoluta recae en el dominio del jus cogens ${ }^{15}$. Siendo así, dichas autoamnistías comprometen la responsabilidad internacional agravada del Estado.

19. Dicha responsabilidad internacional agravada es una consecuencia de la violación del jus cogens $\mathbf{L}_{\mathbf{2}}$ - conformando una ilegalidad objetiva ${ }^{16} \mathbf{L}^{-}$que acarrea otras consecuencias en materia de reparaciones. Ningún Estado puede acudir a artificios para violar normas del jus cogens $^{17}$; las prohibiciones de este último no dependen del consentimiento del Estado ${ }^{18}$. En su

15. A. O'Shea, op. cit. supra n. (2), p. 186, y cf. pp. 198-199, 219 y 222-223.

16. Cf. A. Orakhelashvili, "Peremptory Norms and Reparation for Internationally Wrongful Acts", 3 Baltic Yearbook of International Law (2003) p. 26.

17. Cf. B. Chigara, op. cit. supra n. (9), pp. 151 y 164, y cf. pp. 26, 35-36, 60 y 91.

18. Precisamente para evitar que el Estado recurra a subterfugios para dar encubrimiento a los crímenes perpetrados, en los últimos años se ha fomentado la erosión de los vínculos tradicionales de territorialidad y nacionalidad, para "desnacionalizar" en determinadas circunstancias la administración de la justicia penal y satisfacer los intereses legítimos de la comunidad internacional en esta materia; cf. L. Reydams, Universal Jurisdiction - International and Municipal Legal Perspectives, Oxford, University Press, 2004, pp. 27 y 220-221. Y cf. también Y. Beigbeder, Judging Criminal Leaders - The Slow Erosion of Impunity, The Hague, Nijhoff, 2002, pp. 14 y 207-214. 
muy reciente Sentencia, de hace cuatro días, en el caso Goiburú y Otros versus Paraguay (del 22.09.2006), la Corte Interamericana amplió el contenido material del jus cogens de modo a abarcar el derecho de acceso a la justicia en los planos nacional e internacional, en el sentido en que venía yo propugnando en el seno de la Corte hace ya algún tiempo, tal como señalé en mi Voto Razonado (párrs. 62-68) en este caso.

20. Además, la referida denegación de justicia constituye una violación grave de los artículos 1(1), 2, 25 y 8 de la Convención Americana conjuntamente. El Estado que la comete mediante la imposición de una "autoamnistía" deja de "respetar" y "hacer respetar" los derechos consagrados en la Convención Americana (en los términos del deber general consignado en su artículo 1(1)), deja de armonizar su derecho interno con la normativa de la Convención Americana (en los términos del otro deber general consagrado en su artículo 2), e impide el acceso a la justicia ya no sólo formalmente sino también materialmente ${ }^{19}$ (artículos 25 y 8 de la Convención). O sea, el acceso a la justicia y todo el debido proceso legal pasan a mostrarse comprometidos, denegados que se encuentran por la "autoamnistía"; la interrelación ineluctable entre las disposiciones de los artículos 25 y 8 de la Convención Americana, aquí violadas, es reconocida enfáticamente por la doctrina jurídica contemporánea más lúcida, inclusive en relación con las "autoamnistías", al advertir que

"The right of access to justice is expressed in human rights treaties in the interrelated provisions for the right to a hearing and the right to an effective remedy"20.

21. En última instancia, las autoamnistías violan los derechos a la verdad y a la justicia, desconocen cruelmente el terrible sufrimiento de las víctimas, obstaculizan el derecho a reparaciones adecuadas. Sus efectos perversos, a mi modo de ver, permean todo el cuerpo social, con la consecuente pérdida de fe en la justicia humana y en los verdaderos valores, y una perversa distorsión de los fines del Estado. Originalmente creado para la realización del bien común, el Estado pasa a ser un ente que extermina miembros de segmentos de su propia población (el más precioso elemento constitutivo del propio Estado, su substratum humano) ante la más completa impunidad. De un ente creado para la realización del bien común, se transforma en un ente responsable por prácticas verdaderamente criminales, por innegables crímenes de Estado.

22. Se desprende de la presente Sentencia de la Corte (párr. 152) en el caso Almonacid Arellano que el jus cogens transciende el derecho de los tratados, y abarca el Derecho Internacional general. Y no podría ser de otra forma, por su propia conceptualización como derecho imperativo. La Corte Interamericana determina significativamente, en el cas d'espèce, que

"El Estado no podrá argüir ninguna ley ni disposición de derecho interno para eximirse de la orden de la Corte de investigar y sancionar penalmente a los responsables de la muerte del Sr. Almonacid Arellano. Chile no podrá volver a aplicar el Decreto Ley n. 2.191, por todas las consideraciones dadas en la presente Sentencia, puesto que el Estado está en la obligación de dejar sin efecto el citado Decreto Ley (supra, párr. 144).

19. Cf. A. O'Shea, op. cit. supra n. (2), pp. 270-272, y cf. p. 273.

20. O sea, los derechos consagrados en los artículos 8 y 25 de la Convención Americana; cf. ibid., p. 282 (énfasis acrecentado), y cf. pp. 284 y 288-289. 
Pero además, el Estado no podrá argumentar prescripción, irretroactividad de la ley penal, ni el principio non bis in idem, así como cualquier excluyente similar de responsabilidad, para excusarse de su deber de investigar y sancionar a los responsables" (párr. 150).

23. De ahí el punto resolutivo n. 3 de la presente Sentencia, en el sentido de que "al pretender amnistiar a los responsables de delitos de lesa humanidad, el Decreto Ley n. 2.121 es incompatible con la Convención Americana y, por tanto, carece de efectos jurídicos, a la luz de dicho tratado". O sea, como dicho Decreto Ley carece de efectos jurídicos a la luz de la Convención Americana, no podrá el Estado demando mantener formalmente en vigencia en el plano de su derecho interno, para poner fin a la violación, establecida por la Corte (punto resolutivo n. 2), de los artículos 1(1) y 2, así como 25 y 8, de la Convención Americana (capítulo VIII de esta Sentencia).

24. En el seno de esta Corte, siempre he interrelacionado, en los planos ontológico y hermenéutico, los artículos 25 y 8 de la Convención Americana (como, inter alia, v.g., en mi reciente Voto Razonado - párrs. 28-65 - en el caso de la Masacre de Pueblo Bello versus Colombia, Sentencia del 31.01.2006), en la construcción conceptual del derecho de acceso a la justicia (derecho a la prestación jurisdiccional, derecho al Derecho) como un imperativo del jus cogens. Del mismo modo, desde mis primeros años en esta Corte, he consistentemente interrelacionado los deberes generales de los artículos 1(1) y 2 de la Convención Americana, desde mi Voto Disidente (párrs. 2-11) en el caso El Amparo referente a Venezuela, en la Sentencia sobre reparaciones, del 14.09.1996. En otro Voto Disidente en el mismo caso El Amparo (Resolución del 16.04.1997 sobre Interpretación de Sentencia), sostuve asimismo la responsabilidad internacional objetiva o "absoluta" del Estado por falta de cumplimiento de sus obligaciones legislativas bajo la Convención Americana, de modo a armonizar su derecho interno con sus obligaciones convencionales (párrs. 12-14 y 21-26).

25. Asimismo, en mi Voto Disidente en el caso Caballero Delgado y Santana versus Colombia (Sentencia sobre reparaciones, del 29.01.1997) sostuve, sobre dicha interrelación entre los deberes generales de respetar y garantizar dos derechos protegidos y de adecuar el ordenamiento jurídico interno a la normativa de protección de la Convención Americana (párr. 6), que

"En realidad, estas dos obligaciones generales, - que se suman a las demás obligaciones convencionales, específicas, en relación con cada uno de los derechos protegidos, - se imponen a los Estados Partes por la aplicación del propio Derecho Internacional, de un principio general (pacta sunt servanda) cuya fuente es metajurídica, al buscar basarse, mas allá del consentimiento individual de cada Estado, en consideraciones acerca del carácter obligatorio de los deberes derivados de los tratados internacionales. En el presente dominio de protección, los Estados Partes tienen la obligación general, emanada de un principio general del Derecho Internacional, de tomar todas las medidas de derecho interno para garantizar la protección eficaz (effet utile) de los derechos consagrados.

Las dos obligaciones generales consagradas en la Convención Americana - la de respetar y garantizar los derechos protegidos (artículo 1.1) y la de adecuar el derecho interno a la normativa internacional de protección (artículo 2) - me parecen ineluctablemente interligadas. (...) Como estas normas convencionales vinculan los Estados Partes - y no solamente sus Gobiernos, - también los Poderes Legislativo y Judicial, además del Ejecutivo, están obligados a tomar las providencias necesarias para dar eficacia a la Convención Americana en el plano del derecho interno. El incumplimiento 
de las obligaciones convencionales, como se sabe, compromete la responsabilidad internacional del Estado, por actos u omisiones, sea del Poder Ejecutivo, sea del Legislativo, sea del Judicial. En suma, las obligaciones internacionales de protección, que en su amplio alcance vinculan conjuntamente todos los poderes del Estado (...)" (párrs. 8-10).

\section{La Conceptualización de los Crímenes contra la Humanidad en la Confluencia entre el Derecho Internacional de los Derechos Humanos y Derecho Penal Internacional.}

26. En mi reciente Voto Razonado, de cuatro días atrás (siempre bajo la presión temporal despiadada, y agudizada por los actuales "métodos" acelerados de trabajo de la Corte Interamericana, que no comparto), en la Sentencia en el caso Goiburú y Otros versus Paraguay (del 22.09.2006), situé la conceptualización de los crímenes contra la humanidad en la confluencia entre el Derecho Internacional de los Derechos Humanos y Derecho Penal Internacional. En este anterior Voto Razonado, me permití señalar que los crímenes contra la humanidad

"son perpetrados por individuos pero siguiendo políticas estatales, con la impotencia, o tolerancia, o connivencia, o indiferencia del cuerpo social que nada hace para impedirlos; explícita o implícita, la política de Estado está presente en los crímenes contra la humanidad, inclusive contando con el uso de instituciones, personal y recursos del Estado $^{21}$. No se limitan a una simple acción aislada de individuos alucinados. Son fríamente calculados, planificados y ejecutados.

La tipificación de los crímenes contra la humanidad es una gran conquista contemporánea, abarcando en mi entender no sólo el Derecho Internacional de los Derechos Humanos sino también el Derecho Penal Internacional, al reflejar la condenación universal de violaciones graves y sistemáticas de derechos fundamentales e inderogables, o sea, de violaciones del jus cogens; de ahí la no-aplicabilidad, en casos de su ocurrencia, de los llamados statutes of limitations propios de los sistemas jurídicos internos o nacionales ${ }^{22}$. La configuración de los crímenes contra la humanidad es, a mi juicio, una manifestación más de la conciencia jurídica universal, de su pronta reacción contra crímenes que afectan la humanidad como un todo.

Los crímenes contra la humanidad sitúanse en la confluencia entre el Derecho Penal Internacional y el Derecho Internacional de los Derechos Humanos. Revestidos de particular gravedad, en sus orígenes estuvieron los crímenes contra la humanidad vinculados a conflictos armados, pero hoy día se admite, en una perspectiva humanista, que tienen incidencia en el dominio también del Derecho Internacional de los Derechos Humanos (v.g., en casos sistemáticos de tortura y humillación de las víctimas), denegatorios que son de la humanidad en general, al buscar deshumanizar sus víctimas $^{23}$. Los crímenes contra la humanidad tiene un carácter masivo y sistemático, son

${ }^{21}$. Cf., en ese sentido, v.g., M.Ch. Bassiouni, Crimes against Humanity in International Criminal Law, 2nd. rev. ed., The Hague, Kluwer, 1999, pp. 252, 254-257. Es este el entendimiento subyacente a la Convención de Naciones Unidas contra la Tortura, que criminaliza, bajo el Derecho Internacional, la conduta de agentes del poder estatal; ibid., p. 263, y cf. p. 277.

22. M.Ch. Bassiouni, op. cit. supra n. (21), pp. 227 y 289.

23. Y. Jurovics, Réflexions sur la spécificité du crime contre l'humanité, Paris, LGDJ, 2002, pp. 21-23, 
organizados y planificados como política criminal estatal, - tal como conceptualizados en su jurisprudencia por los Tribunales Penales Internacionales ad hoc para la Ex-Yugoslavia y Ruanda ${ }^{24}$, - son verdaderos crímenes de Estado ${ }^{25}$.

Organizados y planificados por el Estado, en sus más altos escalones, los crímenes de Estado son ejecutados por muchos individuos en cumplimiento de una política criminal del Estado en cuestión, constituyendo verdaderos crímenes de Estado, que comprometen de inmediato la responsabilidad internacional tanto del Estado en cuestión (en el ámbito del Derecho Internacional de los Derechos Humanos) como de los individuos que los ejecutaron ${ }^{26}$. De ahí la importancia de su prevención, dada su especial gravedad, así como de la garantía de su no-repetición" (párrs. 40-43).

27. La Corte Interamericana ha incorporado esta temática en su razonamiento en la presente Sentencia en el caso Almonacid Arellano y Otros versus Chile. En muestra de jurisprudential cross-fertilization, la Corte evoca la jurisprudence constante del Tribunal Penal Internacional ad hoc para la Ex-Yugoslavia (TPIY, Trial Chamber) en el sentido de que un único acto gravemente violatorio de los derechos humanos por parte de un perpetrador puede constituir un crimen contra la humanidad, si cometido dentro de un contexto de una práctica sistemática, resultante de un "sistema político basado en el terror y la persecución" (caso Tadic, 07.05.1997, párr. 649). Lo que está en cuestión es la conducta del Estado, la presencia de un "elemento de policy" (caso Kupre[ki], 14.01.2000, párrs. 550-551). Actos aislados de un perpetrador, si planificados por el Estado, formando una práctica "sistemática" en ejecución de una "política de Estado", constituyen crímenes contra la humanidad (caso Kordic, 26.02.2001, párrs. 176-179).

28. En mi reciente Curso General de Derecho Internacional Público ministrado en la Academia de Derecho Internacional de La Haya (2005), me permití ponderar que, en realidad, ya en los albores del Derecho Internacional, se acudió a nociones básicas de humanidad para regir la conducta de los Estados. Lo que, con el pasar del tiempo, vino a denominarse "crímenes contra la humanidad" emanó, originalmente, del Derecho Internacional consuetudinario ${ }^{27}$, para desarrollarse conceptualmente, más tarde, en el ámbito del Derecho Internacional Humanitario ${ }^{28}$, y, más recientemente, en el del Derecho Penal Internacional ${ }^{29}$.

40, 52-53 y 66-67. Y cf. E. Staub, The Roots of Evil - The Origins of Genocide and Other Group Violence, Cambridge, University Press, 2005 [reprint], pp. 119, 121 y 264.

24. Sobre la jurisprudencia internacional contemporánea sobre crímenes contra la humanidad, cf. J.R.W.D. Jones, The Practice of the International Criminal Tribunals for the Former Yugoslavia and Rwanda, 2a. ed., Ardsley/N.Y., Transnational Publs., 2000, pp. 103-120 y 490-494; L.J. van den Herik, The Contribution of the Rwanda Tribunal to the Development of International Law, Leiden, Nijhoff, 2005, pp. 151-198.

25. Ibid., pp. 93, 183, 192, 199, 228, 278-279, 310, 329-331, 335, 360 у 375.

${ }^{26}$. Cf. ibid., pp. $375-377,403,405-407,441$ y $447-448$.

27. S.R. Ratner y J.S. Abrams, Accountability for Human Rights Atrocities in International Law, Oxford, Clarendon Press, 1997, pp. 45-48.

28. Cf. J. Pictet, Développement et principes du Droit international humanitaire, Genève/Paris, Inst. H.-Dunant/Pédone, 1983, pp. 107 y 77; C. Swinarski, Principales Nociones e Institutos del Derecho Internacional Humanitario como Sistema Internacional de Protección de la Persona Humana, San José de Costa Rica, IIDH, 1990, p. 20. 
Aquí nos encontramos en el dominio del jus cogens, del derecho imperativo. En la ocurrencia de tales crímenes victimizando seres humanos, la propia humanidad es del mismo modo victimizada. Esto ha sido expresamente reconocido por el TPIY (en el caso Tadic, 1997); tales crímenes afectan la conciencia humana (TPIY, caso Erdemovic, 1996) ${ }^{30}$, - la conciencia jurídica universal, - y tanto los individuos agraviados como la propia humanidad tórnanse víctimas de los mismos ${ }^{31}$. Esta línea de entendimiento, que alcanzó el Derecho Internacional Humanitario y el Derecho Penal Internacional contemporáneo, debe, a mi juicio, integrarse también al universo conceptual del Derecho Internacional de los Derechos Humanos. La presente Sentencia de la Corte Interamericana en el presente caso Almonacid Arellano y Otros constituye un primer paso en este sentido.

Antônio Augusto Cançado Trindade Juez

Pablo Saavedra Alessandri
Secretario

29. Cf. D. Robinson, "Defining 'Crimes against Humanity' at the Rome Conference", 93 American Journal of International Law (1999) pp. 43-57; y, para los antecedentes históricos, cf., v.g., H. Fujita, "Le crime contre l'humanité dans les procès de Nuremberg et de Tokyo", 34 Kobe University Law Review (2000) pp. 1-15. - Los crímenes contra la humanidad encuéntranse hoy tipificados en el Estatuto de Roma de la Corte Penal Internacional permanente (artículo 7).

30. J.R.W.D. Jones, The Practice of the International Criminal Tribunals..., op. cit. supra n. (24), pp. 111-112.

31. A.A. Cançado Trindade, "International Law for Humankind: Towards a New J us Gentium - General Course on Public International Law", Recueil des Cours de l'Académie de Droit International de la Haye (2005) cap. XI (en prensa). 